Human Evolution

Elsevier Editorial System(tm) for Journal of

Manuscript Draft

Manuscript Number: HUMEV-E-17-00524R1

Title: A hidden treasure of the Lower Pleistocene at Olduvai Gorge, Tanzania: the Leakey HWK EE assemblage

Article Type: SI: Oldowan-Acheulean

Keywords: Oldowan, Homo habilis, Early Stone Age, Bone Surface Modifications

Corresponding Author: Dr. Michael Pante, Ph.D

Corresponding Author's Institution: Colorado State University

First Author: Michael Pante, Ph.D

Order of Authors: Michael Pante, Ph.D; Ignacio de la Torre, Ph.D

Abstract: HWK EE is a little-known archaeological site from the top of lower Bed II and the basal part of middle Bed II, Olduvai Gorge, Tanzania. The site was originally excavated in the early 1970's by Mary Leakey, but the excavations and the lithic and fossil assemblages that they produced were never described. Here we report for the first time on the lithic and fossil assemblages that were recovered by Mary Leakey from the site. The lithic assemblage is one of the largest of any oldowan site and is characterized by a core-and-flake technology with simple flaking techniques and minimal reduction of cores. Retouched flake frequencies and battered tools are higher than those reported for Olduvai Bed I and Lower Bed II assemblages, but flaking schemes are poorly organized. The fossil assemblage is well-preserved, taxonomically-rich, but dominated by bovids, and includes abundant feeding traces of both hominins and carnivores. Hominins are inferred to have broken the majority of limb bones at the site for access to marrow, while both carnivores and hominins likely had access to at least some flesh. HWK EE may represent one of the last Homo habilis sites at Olduvai Gorge, and is important to understanding the behavioral and cultural mechanisms that led to the emergence of the Acheulean and Homo erectus in the region. 


\title{
A hidden treasure of the Lower Pleistocene at Olduvai Gorge, Tanzania: the Leakey HWK EE assemblage
}

\author{
Michael C. Pante ${ }^{1 *}$ and Ignacio de la Torre ${ }^{2}$ \\ 1 Department of Anthropology, Colorado State University, 1787 Campus Delivery, Fort \\ Collins, CO 80523 USA \\ ${ }^{2}$ Institute of Archaeology, University College London, 31-34 Gordon Square, WC1H OPY, \\ London, UK \\ * Corresponding author: Michael.Pante@ colostate.edu
}

\begin{abstract}
HWK EE is a little-known archaeological site from the top of lower Bed II and the basal part of middle Bed II, Olduvai Gorge, Tanzania. The site was originally excavated in the early 1970's by Mary Leakey, but the excavations and the lithic and fossil assemblages that they produced were never described. Here we report for the first time on the lithic and fossil assemblages that were recovered by Mary Leakey from the site. The lithic assemblage is one of the largest of any Oldowan site and is characterized by a core-and-flake technology with simple flaking techniques and minimal reduction of cores. Retouched flake frequencies and battered tools are higher than those reported for Olduvai Bed I and Lower Bed II assemblages, but flaking schemes are poorly organized. The fossil assemblage is wellpreserved, taxonomically-rich, but dominated by bovids, and includes abundant feeding traces of both hominins and carnivores. Hominins are inferred to have broken the majority of limb bones at the site for access to marrow, while both carnivores and hominins likely had access to at least some flesh. HWK EE may represent one of the last Homo habilis sites at Olduvai Gorge, and is important to understanding the behavioral and cultural mechanisms that led to the emergence of the Acheulean and Homo erectus in the region.
\end{abstract}

\section{Keywords}

Oldowan, Homo habilis, Early Stone Age, Bone Surface Modifications 


\section{Introduction}

Olduvai Gorge remains one of the most important paleoanthropological regions of the world, and has produced dozens of archaeological sites covering the last two million years of human prehistory (Leakey, 1971; Leakey and Roe, 1994). HWK EE (Henrietta Wilfrida Korongo East East) is one of these sites in Bed II, and was excavated by Mary Leakey in the early 1970's. She never published her excavations, perhaps influenced by the fact that her fieldwork at HWK EE was conducted after the publication of the classic monograph on Olduvai Beds I and II (Leakey, 1971). The lithic and fossil assemblages from the site remained in a lab at Olduvai Gorge along with other collections (see Pante, 2010), while the material from most other Bed I and II sites were, until recently, housed by the National Museums of Kenya (and now at the Museum of Dar es Salaam). As a result, HWK EE has received little attention in the literature with references limited to the well-preserved bovid specimens it has produced (Gentry and Gentry, 1978) and its stratigraphic position (Hay, 1976).

Although the assemblages from HWK EE remained hidden for decades, the treasures they offer are no less important. The site is stratigraphically positioned just prior to the appearance of Acheulean technology at Olduvai Gorge dating to roughly 1.7 mya (McHenry and Deino, this volume), and is one of the largest collections of Oldowan lithics from anywhere in the world. It also produced a large and well-preserved fossil assemblage that reflects the feeding ecology of hominins and carnivores at the site. It is likely that HWK EE represents the behavior of Homo habilis near the end of its existence, and is an invaluable reference point for understanding the cultural and behavioral mechanisms that may have led the appearance of Homo erectus and its more advanced Acheulean technology at Olduvai Gorge. 
Here, we present the first detailed analyses of the lithic and large mammal fossil assemblages recovered by Mary Leakey from HWK EE. Our analyses are contextualized by the Olduvai Geochronology and Archaeology Project's (OGAP) own excavation of the site (Figure 1; de la Torre et al., this volume), and will focus on providing an understanding of the lithic technology, paleoenvironment and subsistence patterns of hominins at the site. These interpretations are expanded upon elsewhere based on the lithic (de la Torre and Mora, this volume; Arroyo and de la Torre, this volume) and fossil assemblages (Pante et al, this volume) recovered by OGAP's excavation of the site.

\section{Materials and methods}

Our study is based on the lithic and fossil collection excavated by Mary Leakey at the HWK EE locality and housed in the Leakey camp at Olduvai Gorge in Tanzania, complemented by a catalogue of findings archived in the National Museum of Nairobi, Kenya. This catalogue, hand-written by Mary Leakey, contains the accession numbers of fossils and lithics as they were unearthed during her excavation at HWK EE, and include the lithology and spit each item derived from (Figure 2A), thus enabling us to contextualize the archaeological collection we studied in the Leakey camp.

\section{Contextualizing the HWK EE Leakey collection}

We entered a total of 4351 items (859 fossil specimens and 3492 lithics) into a database that transcribed Leakey's hand-written HWK EE catalogue. We know that only large and/or diagnostic specimens got an accession number in the catalogue, but that the excavated assemblage was bigger (Figure 3A): in total, the HWK EE collection at the Leakey camp that we analyzed contained 2902 lithic items and 1569 fossil specimens. Small bone splinters and lithic debris are generally preserved in the Leakey collections, and although they were not given a unique ID, provenance can be established as they were labelled to the spit they were excavated from. The catalogue also states that unmodified lithics were discarded, 
and so the lithic collection preserved in the Leakey camp is mostly human-made. Nevertheless, larger unmodified materials were given an accession number by Leakey, which enabled us to record their provenance (Figure 2D) and raw material (Table 2).

In 1971, Leakey excavated a trial trench (TT) where she distinguished between materials in a sandy conglomerate and those in clayey tuff/clay underneath, followed by excavations in the main trench (TR1), perhaps also in 1971, and certainly in 1972. Leakey designated 12 spits in TR1 (Figure 1C), which we estimate should have measured at least 31 $\mathrm{m}^{2}$. Spits 1 through 8 were dug through the sandy conglomerate (SC), where she identified two levels of cobbles. Spit 8 also included materials in clays, so part of spit 8 and all spits below (9-12) were ascribed by Leakey to a tuffaceous clay/brown clay unit (see Figure 2C).

Given the high quality of Leakey's earlier field recording techniques at Olduvai (Leakey, 1971), it is likely that she plotted artefact distributions in HWK EE, and described their geological background. However, the whereabouts of maps and field diaries of her excavations are unknown to us. Instead, we rely on the context provided by OGAP's renewed excavations at HWK EE (de la Torre et al, this volume); Leakey's SC can be confidently correlated with the Lower Augitic Sandstone (LAS) interval excavated by OGAP (Figure 2B). In OGAP's T1-Main Trench, the LAS is a thick deposit with several archaeological units (L1-L1A to L8), which is consistent with the higher number of spits (1-8) excavated by Leakey in the SC. Although OGAP's excavations in T1-Main Trench identified more than two levels of cobbles (see de la Torre et al, this volume), the large number of unmodified rocks in Leakey's spit 8 (see Figure 2D), in the contact with the clay, is consistent with the stratigraphic position of OGAP's archaeological unit L6-LCHA. Apart from the good match in frequency of objects in both OGAP and Leakey units, many of the Leakey artefacts from the lower spits (particularly spit 12) have root-like carbonate encrustations identical to those from Level 10 in OGAP's T1-Main Trench. In addition, fossil to stone tool ratios of both the 
catalogue and the actual HWK EE Leakey collection housed in the Leakey camp (Figure 3A) show a higher abundance of fossils in the clay and of stone tools in the SC, which is again consistent with proportions unearthed by OGAP. Therefore, Leakey's tuffaceous clay/brown clay (clay throughout) unit can be generally correlated with OGAP's L10 (Figure 2B), and thus ascribed to the Lemuta interval (see details in de la Torre et al, this volume).

In summary, while it is not possible to correlate each of Leakey's spits to OGAP's archaeological units, we can confidently attribute her SC collection to the LAS assemblage presented by de la Torre et al (this volume), and Leakey's materials in clay to OGAP's Lemuta. This has implications for the interpretation of the paleoecology of the Leakey assemblage (Bibi et al, this volume; Prassack et al, this volume; Rivals et al, this volume, Uno et al., this volume), the discussion of site formation processes (de la Torre et al, this volume), and also for comparisons of flaking (de la Torre and Mora, this volume) and percussive technology (Arroyo and de la Torre, this volume), and subsistence patterns (Pante et al, this volume).

\section{Analytical methods}

Stone tool technology was studied by IT following a macroscopic approach, using standard literature on East African Early Stone Age lithic analysis (Leakey, 1971; Isaac et al, 1997; Toth, 1982), and recent advances on the study of core reduction methods (de la Torre and Mora, 2005, this volume; de la Torre, 2011) and pounded artefacts (Mora and de la Torre, 2005; Arroyo and de la Torre, this volume). Raw material classification draws on results of an accompanying paper (McHenry and de la Torre, this volume), where details of rock types in the HWK EE Leakey collection are expanded. Given the limited amount of contextual data available for the Leakey collection, a taphonomic assessment of the HWK EE lithics is presented in an accompanying paper (de la Torre et al, this volume), and here we will focus on technological aspects of the assemblage. 
A taxonomic and taphonomic analysis of fossils was conducted by MP. Taxonomic identifications were made using comparative collections of modern African fauna. Taphonomic analyses were conducted following Blumenschine et al., (1996), and also considered published descriptions of bone surface modifications in addition to mammalian carnivore tooth marks and stone tool cut and percussion marks. These include trampling, crocodile tooth marks, and bioerosion (Njau and Blumenschine, 2006; Blumenschine et al., 2007; Domínguez-Rodrigo et al., 2009a). Each fossil was examined under a 60-watt light source, first without magnification and then using a 10x hand lens, while systematically altering the angle of the bone surface relative to the light source. Notable marks were photographed with a Nikon d7100 camera and Helicon focus bracketing software. A few marks were photographed using a scanning electron microscope located in the Institute of Archaeology, University College London.

Results for the HWK EE Leakey assemblage are compared with feeding trace models described elsewhere in more detail (Blumenschine 1995; Capaldo; 1995; Pante et al., 2012; Pante et al., this volume). The models comprise different feeding scenarios and are based on naturalistic and experimental observation of carcass consumption by humans, carnivores and, in some cases, vultures. The models can be broadly divided into either control samples or simulations of either primary or secondary access to carcasses by hominins. Control samples are scenarios in which only one consumer has modified a carcass and include the carnivore only (CO) and hammerstone only (HO) models. Simulations of primary access to carcasses by hominins include the whole-bone-to-carnivore (WB-C) and the hammerstone-carnivore $\mathrm{H}$ C models. In the WB-C model, humans extracted flesh from carcasses, and carnivores had access to marrow and grease. In the $\mathrm{H}-\mathrm{C}$ model, humans extracted flesh and marrow, and carnivores ravaged the resulting fragments for grease. The lone simulation of scavenging is the vulture-hominin-to-carnivore (V-H-C) model, in which vultures and in some cases 
carnivores defleshed carcasses, humans consumed the marrow, and carnivores ravaged the hammerstone broken bones for grease. Each feeding trace model is characterized using the means and $95 \%$ interquantile ranges for the incidences of tooth, cut and percussion marks, which represent the values for assemblages that comprise each model (see Pante et al., 2012). The interquantile ranges can be interpreted like a 95\% confidence interval, so when the HWK EE assemblage falls within these ranges, the processes that led to the formation of the assemblage cannot be distinguished from those of the model.

To enhance comparisons between the HWK EE assemblage and the feeding trace models, it is necessary to create a comparative sample, which excludes specimens that were altered by other taphonomic processes. Such processes include post-depositional breakage, which can have an unknown effect on mark frequencies, and fluvial rounding, which can obscure surface modifications (Shipman and Rose, 1983). The comparative sample excludes 1) bones that are not from the limb; 2) bones that were determined to be dry or recently broken by the presence of step or transverse fractures; 3) bones less than $20 \mathrm{~mm}$ in max dimension; 4) bones from animals larger than size 4 , or from those known to be from a taxonomic family other than Bovidae; and 5) those with a surface condition that was likely to obscure modifications.

The minimum number of elements (MNE) for fossils was calculated independently for the SC and clay units. All fossils were first analyzed for skeletal part and portion and then laid out by element and animal size group to identify overlapping portions for each skeletal part. When overlap occurred, the MNE was increased. The MNE estimates for limb bones considered both midshaft fragments and epiphyses. Refits were attempted between specimens of the same animal size and from the same element and stratigraphic unit, but none were found.

\section{Results}




\section{$\underline{\text { The lithic assemblage }}$}

\section{General composition of the assemblage}

Table 1 and Figure 3B show that the original assemblage was dominated by unmodified lithics (mostly cobbles, according to Leakey's catalogue), which were particularly abundant in the SC (61.4\%), but also dominant (42.9\%) within the clay unit. As shown in Table 2, such unmodified material was overwhelmingly dominated by lavas, which made up (considering the unspecified lavas and the phonolite, trachyte and basalt) $95.2 \%$ of the natural rocks documented by Leakey. As discussed above, Leakey did not curate any lithics she deemed as unmodified, discarding these and some other lithic specimens (1889 records of the catalogue were listed as discarded material).

Unmodified material aside, the disparity between Leakey's breakdown of categories (Table 1) and ours (Table 3) is most evident in debitage (i.e. detached) frequencies. This is an artefact of Leakey's cataloguing bias in favor of larger specimens (e.g. cores and pounded tools) whereas, as discussed in the earlier section, smaller artefacts (i.e. debitage) were labelled to the spit but not inventoried.

A full picture of the original lithic assemblage that considered both the unmodified material (catalogued, but not curated) and the whole debitage sample (mostly curated, but often not given an accession number in the catalogue), would have to combine counts from Table 1 and Table 3, and would total $~ 5000$ lithic specimens (i.e. 2902 lithics currently curated in the Leakey camp, plus 2055 unmodified specimens inventoried in the catalogue). This figure does not consider the smallest debitage, which we know was abundant in the HWK EE deposits (de la Torre et al, this volume), but was not catalogued or curated by Leakey. A total of 53 lithics, currently curated in the Leakey camp, were also considered in our study as unmodified, so in order to account for the pre-existing bias against unmodified 
material, they were excluded from our analysis, which in the next sections focuses on the human-made assemblage $(\mathrm{n}=2849 ; 230 \mathrm{~kg})$.

Technological categories

Debitage (70.6\%) dominates the entire HWK EE assemblage, although it is higher in the clay unit (79.8\%) than in the SC (65.7\%) (Table 3). Detached pieces are mostly flake fragments and shatter (Figure 3E) in both units. The second most frequent category in the SC is cores $(26.6 \%)$, which are also abundant in the clay unit, although in a lower proportion (15.1\%) (Figure 3F). Retouched tools show similar relative frequencies in both units (see Table 3), with an average of $2.4 \%$. The relative frequency of pounded tools is twice as high in the SC (3.9\%) as within the clay unit (1.6\%), and dominated by knapping hammerstones in both assemblages (Table 3).

Figure $3 \mathrm{C}$ shows the overwhelming dominance of quartzite in the entire assemblage. Although quartzite abundance is consistent in both detached, flaked and pounded artefacts (Figure 3D), Table 4 shows most quartzite specimens are detached artefacts $(n=1851)$. The entire assemblage of quartzite amounts to $78 \mathrm{~kg}$, whereas the lava assemblages total $153 \mathrm{~kg}$, so in terms of total amount of worked material, the latter rock types are more prevalent. In fact, lava cores (phonolite, trachyte-trachyandesite and basalt combined) constitute $53.8 \%$ of the flaked artefacts, a proportion that is dramatically lower $(5.3 \%)$ within the detached material. Chert artefacts are only $2.9 \%$ of the entire assemblage and amount to $2.5 \mathrm{~kg}$, with a clear imbalance between flaked (4.8\% of the total of this group) and detached pieces $(2.3 \%$ of debitage) (see absolute frequencies in Table 4).

\section{Debitage}

Whole flakes $(\mathrm{n}=345 ; 9.8 \mathrm{~kg}$ ) make up $12.1 \%$ of the entire assemblage, and represent a significantly lower proportion of the assemblage than fragmented flakes (32.9\%) and shatter (see Table 3). The percentage of whole flakes is similar in both the SC (11.2\%) and 
the clay unit (14.1\%). Flakes have an average length of $\sim 38 \mathrm{~mm}$ and weight of $\sim 28 \mathrm{~g}$ (Table 5), with most of them within the 20-39 mm length class (Figure 4A). As shown in Figure 4B, differences exist in flake length ranges according to raw material type; most of quartzite flakes are smaller than $4 \mathrm{~cm}$, whereas the $40-59 \mathrm{~mm}$ length class predominates among the lavas, which also have larger proportions of flakes greater than $6 \mathrm{~cm}$ (Figure 5A). Chert has a size distribution that is more similar to quartzite than to lava, although chert flakes greater than $20 \mathrm{~mm}$ have the highest representation of the three raw material groups (see recounts in Table 6).

Flake striking platforms are predominantly unifacetted (Table 6, Figure 4C), although cortical butts are also common overall (25\%), especially among the lava flakes (40\%). Bifacetted striking platforms are rare in the entire sample $(2.5 \%)$, but they are several times more frequent in chert $(9.1 \%)$ than in lava $(4.4 \%)$ or metamorphic $(1.9 \%)$ flakes. While $60.9 \%$ of flake dorsal surfaces were coded as cortex-free (see Table 6), only $24.4 \%$ of lava and $7.7 \%$ of chert flakes showed no cortex on their dorsal sides, and it is the quantitative dominance of metamorphic flakes that conditions the overall low cortex average. Expectedly, a similar pattern is observed when striking platform and dorsal side cortex indices are considered together (Figure 4D); the three raw material groups combined show a predominance of Toth's type VI (48.8\%), but when metamorphic rocks are not considered, cortex-free flakes only account for $15.6 \%$ (lavas) and $9.1 \%$ (chert) (see details in Table 6). Cores

The HWK EE Leakey assemblage contains a remarkably large number of cores $(\mathrm{n}=642 ; 172 \mathrm{~kg})$, which enables a quantitative analysis of their attributes. Most cores have a maximum length of $60-79 \mathrm{~mm}(\sim 38 \%)$ or $80-99 \mathrm{~mm}(\sim 31 \%)$, and an average weight between 201-400 g (38\%) and 101-200 g (24\%) (Table 7). Figure 6A and 6C show that core length and weight patterns of the two stratigraphic units are similar, although those from the SC are 
slightly larger. Size differences are more conspicuous between raw materials; Figure 6B shows that metamorphic core length patterns follow a decreasing trend from 4 to $10 \mathrm{~cm}$, which is exactly the opposite among lava cores. Differences are accentuated by core weight ranges (Figure 6D), where $79.3 \%$ of lava cores are heavier than $200 \mathrm{~g}$, as opposed to metamorphic cores, which are mostly (73.3\%) under $200 \mathrm{~g}$ (see values in Table 7).

Nearly all cores $(96 \%)$ preserve some degree of cortex, and they show similar cortical ratios across the clay and SC units (Figure 6G). However, there are clear differences per raw material again; $75.3 \%$ of lava cores preserve most of the cortex, as opposed to much lower cortical coverage in metamorphic and chert cores (see Figure $6 \mathrm{H}$ and Table 7).

Selection of flaking blanks is relatively similar throughout the two intervals, with most of cores being made on cobbles $(60.2 \%$ in the SC and $51 \%$ in the clay unit), followed by fragments in the SC (21.6\%), and blocks in the clay unit (23.5\%). Lava cores were almost exclusively made on cobbles $(91.5 \%)$, chert cores on nodular blanks $(77.8 \%)$ and metamorphic cores on blocks (39.9\%) or fragments $(50.5 \%)$ (see Table 7$)$.

Scar number patterns are nearly identical in the SC and clay units (Figure 6E), with most of cores presenting an average of 4-6 previous extractions (46.2\%), followed by those with 1-3 scars (38.6\%). Metamorphic and chert cores show a dominance of 4-6 scar patterns (51.6\% and $58.8 \%$, respectively), whereas most of lava cores have three scars or less $(43.8 \%)$

Figure 7A shows BSP reduction as the commonest flaking scheme when the entire core assemblage is considered, followed by BALP and USP, and also with relatively abundant frequencies of TC and MLT cores (see values in Table 8, and description of abbreviations in the caption of Figure 7). Comparison of freehand flaking schemes in the two stratigraphic intervals (Figure 7B) indicates that prevalence of BSP in the entire assemblage is due to high numbers in the SC unit. In fact, MLT cores are more frequent than BSP in the 
clay unit. Apart from this divergence in MLT and BSP proportions, the SC and clay units share similar frequencies of most other freehand cores (see Table 8), with the possible exception of BP-flaked cores, which proportionally are twice as common in the clay as in the SC. In addition to the comparison of freehand flaking schemes throughout the sequence (Figure 7B), Table 8 shows that, proportionally, the bipolar technique is also twice as abundant in the clay as in the SC, thus providing another element of distinction between the two stratigraphic units.

Some patterns also exist when flaking schemes are considered per raw material (Figure 7C). BSP and USP (Figure 8) predominate among the lavas, followed by BALP (Figure 9). The low number of chert cores prevents comparison with other raw materials, although there seems to be preference for BSP, TC and MLT reduction. The metamorphic core assemblage is large $(\mathrm{n}=232 ; 47.8 \mathrm{~kg})$ and therefore can be more realistically compared to lavas $(\mathrm{n}=370 ; 122.1 \mathrm{~kg})$; as shown in Figure 7C, BSP and USP proportions are much lower in metamorphic cores. While most other freehand schemes have similar frequencies in both raw materials, the relative higher proportion of unifacial abrupt metamorphic cores (particularly for the UAU2 scheme), is substantial (see values in Table 8 and examples in Figure 10). Probably the most relevant difference between the two raw materials is in the bipolar technique which, albeit not predominant among metamorphic cores $(10.34 \%)$, is still far more common than in lavas $(1.35 \%)$.

\section{Retouched pieces}

Retouched tools only represent $2.4 \%(\mathrm{n}=67 ; 2.9 \mathrm{~kg})$ of the entire assemblage, and have similar proportions in both the SC and clay units (see Table 3). 53.7\% of them are made on quartzite, followed by chert (23.9\%), phonolite (11.9\%), basalt (7.4\%), and others. Most of them used whole flakes $(56.7 \%)$ or fragmented flakes $(38.8 \%)$ as blanks. Blanks selected for retouching were preferentially non-cortical $(42.8 \%)$ or preserved less than $50 \%$ of cortex 
(38.1\%) on their dorsal surfaces, with only a few flake/flake fragments that were mostly cortical $(14.3 \%)$ or completely cortical $(4.76 \%)$.

As shown in Table 5, retouched tools average $45.9 \mathrm{~mm}$ in length, and are therefore longer than unmodified flakes $(38.6 \mathrm{~mm}$ ), and consistently heavier (43.4 g vs $28.6 \mathrm{~g}$ ). Most of retouched tools are denticulates (89.2\%), alongside some convergent tools (6.1\%) and sidescrapers with continuous retouch (4.6\%) (Figure 11).

\section{Pounded tools}

Battered pieces are not numerically important $(n=89)$, but their overall weight contribution $(27.5 \mathrm{~kg})$ is greater than other groups such as debitage $(22.4 \mathrm{~kg})$. As shown in Table 3, the SC has a much higher frequency of pounded artefacts than the clay unit, and some categories such as subspheroids are only present in the more recent stratigraphic interval. Quartzite seems to dominate the pounded tool assemblage (Figure 3D), but when phonolite, trachyte-trachyandesite and basalt are considered together, the proportion of lavas $(67.4 \%)$ is clearly larger.

Active elements (sensu Chavaillon, 1979) include regular knapping hammerstones, the most frequent pounded tools in the assemblage, and subspheroids. Both share similar dimensions and virtually the same average weight (see Table 5), although all HWK EE subspheroids show scars indicating a flaking sequence before or after surfaces were battered. Active or passive function of pitted stones is a subject of debate (see Arroyo and de la Torre, this volume), but their larger dimensions and their average weight at HWK EE (considerably heavier than that of hammerstones; see Table 5) could indicate a stationary use as anvils. As with subspheroids, pitted stones also bear flaking scars, indicating their polyvalent use as cores and battering tools. Some pounded pieces bear pitting on the center of the blank instead 
of at the ends, which is typical of regular knapping hammerstones; this suggests an orthogonal motion, potentially related to their use as active hammers during bipolar flaking. The fossil assemblage

A total of 1382 large mammal specimens could be tied to either the clay or the SC unit (Table 9). 1126 of these specimens were bones and 256 were teeth. The majority $(n=900)$ come from the clay unit. There is a greater disparity between the number of bones compared with the number of teeth between the units. The sample of limb bones used for comparison with feeding trace models (comparative sample) is shown in Table 10. The sample size in the comparative sample for the SC unit is small particularly when broken down by size group and bone portion.

\section{Length of limb bone midshaft fragments}

The length of limb bone midshaft fragments in the comparative samples from the SC and clay units shows that they are both deficient in small specimens that measure less than 40 $\mathrm{mm}$ in maximum dimension, when compared with the feeding trace models (Figure 12). The most abundant specimens in the clay unit measure between 50 and $60 \mathrm{~mm}$, while those greater than $100 \mathrm{~mm}$ in maximum length make up the largest proportion of the comparative sample from the SC unit.

\section{Minimum number of individuals}

A total 55 individuals are represented in the Leakey collection from HWKEE, with 32 coming from the clay unit and 23 from the SC unit (Table 11). The assemblage is taxonomically-rich, but dominated by alcelaphin bovids. Some of the taxonomically identifiable specimens are nearly complete allowing attribution to species (see Figure 13 for examples). Two species of equids are represented, the large Equus cf. oldowayensis and the smaller Eurygnathohippus cf. cornelianus. There are two genera of giraffids represented in the SC unit, but only one in the clay. Rhino and hippo were found in the clay but not the SC, 
while only the SC unit preserved proboscideans. Carnivores and a lone primate, Theropithecus cf. oswaldi, are found in the SC, but not in the clay unit. Suids are more common in the clay unit with two species of the genus Kolpochoerus represented, while only one species, Metridiochoerus cf. compactus, was found in the SC. Crocodiles are well represented by isolated teeth, but only two other elements (a maxilla and vertebra). were identified as crocodile.

\section{Skeletal part profiles}

A total of 446 elements were recovered from the two stratigraphic units (Table 12). 233 were identified from the clay unit and 213 from the SC unit, showing that representation of elements is more equal than the number of fragments would suggest. The relative abundance of elements by skeletal group is similar for both units and follows from greatest to least abundance; compact, appendicular, axial, cranial and pelves/scapulae. The only exception is an equal representation of axial and cranial bones in the SC unit. The number of limb bone elements from both intervals show a deficiency of ulnae and a dominance of tibia. The femur is also more abundant in the SC unit relative to other limb bones, but with the exception of the tibia, the representation of limb bones is relatively equal in the clay unit.

\section{Taphonomy}

Assemblages from the SC and clay units are both well-preserved. Fossils exhibit only minor weathering with roughly $83 \%$ falling in weathering stages 0-1 (Table 13). Mechanical rounding severe enough to obscure surface modifications represents only about $12 \%$ of fossils in both units, while roughly $26 \%$ of fossils exhibit major exfoliation of their cortical surfaces. The condition of cortical surfaces is slightly better in the clay unit, with about $75 \%$ of fossils having surfaces good enough to preserve bone surface modifications, compared with about $69 \%$ for the SC unit.

Bone surface modifications 
The HWK EE Leakey assemblage preserves percussion, tooth, and cut marks (Table 14, Figure 14). The proportion of specimens that bear these feeding traces is high in the comparative samples from the SC and clay units, and falls within the $95 \%$ interquantile ranges of some of the feeding trace models. Also present in the clay unit, but not the SC, are crocodile tooth marks $(n=3)$.

\section{Percussion marks}

The incidence of percussion marking in the HWK EE assemblage is most similar to that reported for the V-H-C model. Nearly all size group and portion sub-samples of the clay and SC units fall within the ranges reported for the V-H-C model, with the exception of the size group 1-2 sub-sample of midshaft fragments from the SC unit. The all limb bone fragment sub-samples for size group 3-4 animals from both units also fall within the 95\% interquantile range of the H-C model. For midshaft fragments, both units fall with the range of the size group 3-4 sub-sample of the HO model, while the size group 1-2 sub-sample from the clay unit also falls within that of the HO model. Lastly, the size group 3-4 sub-sample of midshaft fragments from the SC unit falls within the range of the $\mathrm{H}-\mathrm{C}$ model.

\section{Tooth marks}

The incidence of tooth marking in the HWK EE assemblage is higher than ranges reported for most sub-samples of the feeding trace models. For all long bone fragments, the SC and clay units only fall with the range of the size group 1-2 sub-sample of the V-H-C model. For midshaft fragments, the sub-samples of both units fall within the size group 3-4 sub-sample of the WB-C model. The size group 1-2 sub-sample of midshaft fragments from the clay unit also falls within the range of the V-H-C model.

Cut marks

The incidence of cut marking in the HWK EE Leakey assemblage is higher for size group 3-4 animals than for the smaller size group 1-2 animals. The all limb bone fragment 
size group 3-4 sub-samples of both units fall with the range of the V-H-C model. They are both also similar to the H-C model, but only the value for the SC unit falls within the reported range of the model, while the sub-sample for the clay unit falls just below it. For midshaft fragments, the SC unit only falls within the size group 3-4 sub-samples of the $\mathrm{HO}$ and $\mathrm{H}-\mathrm{C}$ models. The absence of cut marks in the size group 1-2 sub-sample of this unit is only accommodated by the V-H-C model. Cut mark values for midshaft fragments from the clay unit fall within all size group sub-samples for the $\mathrm{HO}$ and WB-C models, and also the size group 3-4 sub-sample of the H-C model.

\section{Discussion}

The lithic assemblage

The Leakey HWK EE lithic assemblage is one of the largest for any Oldowan site in East Africa, amounting to $230 \mathrm{~kg}$ of human-modified rocks. While the absence of unmodified lithics and smallest debitage fraction is certainly an artefact of collection bias, imbalance observed in other categories requires alternative explanations. The most obvious one concerns the massive number of cores $(n=642)$ preserved in the assemblage, which in itself would constitute an interpretive challenge, but gets amplified when contrasted to the amount of debitage. We counted (using very conservative estimates) a minimum of 2174 scars in a sample of 487 cores, resulting in an average of 4.4 extractions per core. If extrapolated to the entire core sample, it would be expected to record at least 2824 flakes; however, as shown in Table 3 not even the sum of flakes and flake fragments comes close to that estimate. This large deficit is particularly acute in lavas, which have the largest proportion of cores $(n=348)$, and yet the lowest frequency of debitage $(n=108)$. While hydraulic sorting may explain in part the overall deficit of debitage (see discussion in de la Torre et al, this volume), postdepositional processes alone do not clarify the special deficit of lava flakes, and therefore 
human behavioral interpretations accounting for a differential treatment of raw materials should be sought (see de la Torre and Mora, this volume).

Indeed, the HWK EE lithic assemblage shows specific technological patterns for each raw material (see extended discussion in de la Torre and Mora, this volume). Numerically, the most abundant material is quartzite, but that is due to a higher frequency of debitage. In terms of the overall contribution of raw material to the assemblage, there is much less in weight of quartzite than of lavas. Therefore, the numerical predominance of quartzite is measuring higher fragmentation intensity (or in situ knapping), rather than the amount of raw material units that were used by hominins, which is far larger for lavas. Some categories are nonetheless clearly associated with quartzite; bipolar cores are a minority in the overall HWK EE assemblage when compared to free-hand flaking, and yet $82.7 \%$ of bipolar cores are made of quartzite despite lava cores being, in general, much more abundant. The same applies to polyhedrons (see Figure 9) which, albeit scarce in HWK EE, are in some instances prototypical (i.e., showing obtuse scars and battering over earlier flaking/shaping) and are also preferentially made on metamorphic rocks $(77.78 \%)$. As discussed earlier, unifacial abrupt methods are also preferentially associated with quartzite; this is certainly linked to the original form of blanks, which as cuboid shapes provide angles that facilitate unidirectional flaking from one natural striking platform. The abundance of UAU2 metamorphic cores is interesting, as it suggests that knappers were searching for additional natural flaking edges once the first had lost suitable angles, rather than reactivating the original surfaces through bifacial reduction. This strategy was extended to multifacial flaking in the larger blocks; with few exceptions, all big quartzite cores analyzed here were multifacial, suggesting that knappers were striking flakes from whichever angle was available. Whole flakes are a testimony to this expedient strategy; most flakes are small, show no previous scars, and the 
larger ones preserve the original morphology of the blocks they derive from (i.e. butts and distal ends that remove parts of the flat, cleavage natural surface of blocks).

The chaîne opératoire of lavas is also distinctive. Apart from the dramatic deficit of debitage (there are 0.3 flakes/flake fragments/shatter per core), lava flakes are characterized by their larger size when compared to other raw material groups, and a predominance of cortex in their dorsal and striking platform sides (Figure 5). This general lack of previous removals on the flakes is consistent with features observed in the cores, which mostly present less than three scars, attesting to extremely short reduction sequences. Lava cores are almost invariably made on cobble blanks, which we know from OGAP's excavations are identical to the unmodified cobble assemblage (de la Torre et al, this volume; de la Torre and Mora, this volume). Knapping schemes mostly rely on flaking of one single edge of the cobble blank, either unifacially (usually USP) or bifacially (BSP, BALP, and also BAP), leading to the classic 'chopper' morphology defined by Leakey (1971) (Figure 8 and Figure 9). In HWK EE, these schemes are very similar to each other, and seem to respond to the rounded (and difficult to flake) shape of blanks, whereby short sequences of flakes are obtained from unifacial natural striking platforms (mostly USP), through bifacial alternating flaking (BALP), clearance of the striking surface prior to flake removals (BAP), or through unorganized flaking of a bifacial edge (BSP).

Chert is numerically unimportant in the context of the entire assemblage, but evidences the application of a different set of solutions adapted to specific traits of this raw material. Despite its scarcity in the whole assemblage, chert accounts for a substantial proportion of the retouched tools (see percentages above). Within the group of chert $(n=84)$, there are more retouched flakes $(19 \%)$ than unmodified ones $(16.6 \%)$, a pattern which is unseen in any other raw material. 
Chaînes opératoires of percussive tools also show clear raw material patterns. All subspheroids are made of quartzite. Lavas were preferentially used as flaking hammerstones, which is not unexpected given the rounded and smooth shape of lava cobbles as opposed to the usually blocky morphology of quartzite and the irregularity of chert nodules. Pitted stones are also found only among lavas, although in this case it cannot be attributed with certainty to human selection, because pits are not easily produced on quartzite due to the crystal structure of this raw material (de la Torre et al, 2013).

Discussion of diachronic patterns is hindered by the substantial difference in the amount of material between the clay and SC units, which is in itself probably a consequence of post-depositional factors, and is discussed elsewhere (de la Torre et al, this volume). Despite this, some variation seems to exist between the two intervals, such as the higher frequency of bipolar and a potentially higher reduction intensity in the older sequence, and the existence of subspheroids in the upper unit only (see further discussion in de la Torre and Mora, this volume).

Regardless of these variations, HWK EE technological patterns indicate very short reduction sequences, where the main objective is the production of debitage. Flaking schemes are rarely organized, often affecting only one area of a core. Edges were reduced with naturally suitable angles and no apparent volumetric management. Extractions only sought to exploit ad hoc any available edges regardless of whether flaking was unifacial, bifacial or multifacial. Most of flaking schemes were freehand, although the presence of pitted anvils, some hammerstones with battering on central areas, and cores with distal crushing, indicate that a bipolar technique was also used occasionally. Shortness of reduction sequences applies to all raw materials, but is especially conspicuous in lavas, which are inferred to have been available in the immediate surroundings of HWK EE (see de la Torre et al, this volume; McHenry and de la Torre, this volume). Quartzite blocks (some of them over $1.5 \mathrm{~kg}$ ) were 
likely sourced by hominins from Naibor Soit, so this longer distance could explain the higher fragmentation intensity evidenced in the metamorphic debitage, even though this by itself does not account for the deficit of lava flakes. Given the larger collection and better contextual control of the OGAP collection, this and other behavioral indicators are discussed further in an accompanying paper (de la Torre and Mora, this volume).

In summary, the HWK EE Leakey lithic assemblage is characterized by a core-andflake technology very similar to that of other Oldowan sites in the same stratigraphic interval such as FLK N SC and HWK E (Leakey, 1971; de la Torre and Mora, 2005; Proffitt, this volume), where simple flaking techniques are accompanied by an increase of retouched flake frequencies and battered tools (particularly spheroids/ subspheroids) when compared to Olduvai Bed I and Lower Bed II.

The fossil assemblage

The Leakey HWK EE fossil assemblage is well-preserved, but like the lithic assemblage, influenced by collection bias. The size of the fossil assemblage is modest with regards to smaller-sized specimens, and limits the measures that can be used to interpret the feeding behavior and ecology of hominins at the site. This is particularly true when the assemblage is divided into the two stratigraphic units and the portion and size sub-samples used for comparison with the feeding trace models, some of which have as little as four specimens within them. The comparative sample shows a deficiency of small specimens, which dominate the fossil assemblage from OGAP's excavation of the site (Pante et al, this volume). The lack of smaller specimens likely has a bigger impact on both the skeletal part profiles and incidences of feeding traces in the assemblage than it does on the taxonomic composition. The former relies on the inclusion of these small specimens to accurately describe an assemblage (Blumenschine, 1995; Marean and Frey, 1997), while it is unlikely that taxonomically identifiable specimens were discarded. Even with the apparent collection 
bias in the HWK EE Leakey fossil assemblage, the results are mostly consistent with those reported for the assemblage excavated by OGAP from the site (de la Torre et al., this volume; Pante et al., this volume).

The taxonomic richness of the HWK EE Leakey fossil assemblage suggests an open habitat at the site. Grazers dominate the assemblage and the browsers that are present, such as tragelaphin bovids and the extinct proboscidean Deinotherium, are represented by only a few individuals out of the 55 that comprise the assemblage. Water was likely abundant at the site, at least seasonally, indicated by the presence of crocodiles, hippos and fish in OGAP's assemblage (see Bibi et al., this volume). This water source may have provided at least some tree cover, as suggested by the birds present (Prassack et al., this volume), and likely attracted hominins, carnivores, and herbivores to the site. Hominins at the site would have been at risk of predation from both mammalian carnivores and crocodiles, and this may have limited their activities at HWK EE. However, the large number of stone tools and butchered animal bones suggests the affordances of HWK EE were great enough to outweigh the risk of predation.

The skeletal part profiles in the Leakey HWK EE fossil assemblage show that most elements are represented in both stratigraphic units. Low- (e.g. vertebrae, ribs and podials) and high-density (limb bones and mandibles) skeletal parts are present in both units, but lowdensity elements appear to be underrepresented compared with their relative abundances in the mammal skeleton. This may reflect the effect of fluvial processes on the assemblage, as low-density elements are more likely to be transported than their high-density counterparts (Voorhies, 1969; Behrensmeyer, 1975). However, the effect of fluvial processes on the fossil assemblage excavated by OGAP was determined to be minimal (Pante et al, this volume), and the effect of collection bias on the skeletal part profiles of the assemblage is unknown, but possibly substantial. The relatively even distribution of limb bones in both stratigraphic units is consistent with results for the fossil assemblage excavated by OGAP from HWK EE 
(Pante et al., this volume), and suggests fore and hind limbs were transported to the site in relatively equal proportions, although the relatively small sample sizes for the HWK EE Leakey assemblage could have affected the results.

The preservation of cortical surfaces in the Leakey HWK EE fossil assemblage is generally good in both stratigraphic units. Weathering is minimal, with most fossils exhibiting only minor or no cracking resulting from long term exposure to sunlight, moisture and fluctuating temperatures (Behrensmeyer, 1978). This suggests that the HWK EE assemblage was buried quickly after deposition. Exfoliation, fluvial abrasion, and other taphonomic processes obscured $25-30 \%$ of bone surfaces in the assemblage, but this effect is considered relatively minor compared to fossil assemblages where most or all cortical surfaces are poorly preserved, such as the assemblage excavated from EF-HR by OGAP (de la Torre et al., this volume), 'b'. The conditions that conserved the HWK EE assemblage and protected the cortical surfaces of fossils also preserved abundant feeding traces of hominins and carnivores.

The incidences of percussion, tooth, and cut marks in the comparative sample of the Leakey HWK EE fossil assemblage are high, suggesting most carcasses at the site were consumed by hominins, carnivores, or both. Size and portion sub-samples from both stratigraphic units are most often within the $95 \%$ interquantile ranges of the V-H-C model, which simulates hominin scavenging from carcasses defleshed by vultures and, in some cases, minimally by carnivores. The results for the Leakey assemblage are similar, but not identical, to those reported for the OGAP assemblage from HWK EE. Small sample sizes and collection bias likely affected the results for the Leakey assemblage, particularly for the SC unit, where the sample of four midshaft specimens for size group 1-2 animals are devoid of modifications. This is less of a problem for the clay unit where the sample is larger, but still biased. 
The values for percussion marks in both stratigraphic units suggest hominins broke the majority of limb bones at the site. The results for the Leakey assemblage are almost always higher than those reported for the OGAP assemblage (Pante et al., this volume), especially for size group 1-2 fragments. This is likely the result of collection bias towards larger fragments that are more likely to preserve bone surface modifications (Blumenschine, 1995; Faith, 2007). However, the interpretations of the OGAP and Leakey assemblages based on percussion marks are the same, as most sub-samples fall within the ranges of the same feeding trace models.

The values for tooth marks in both stratigraphic units show a strong carnivore signal, and are generally higher than feeding trace models where hominins are simulated as having had primary access to flesh. This suggests hominins may have scavenged at least some of the carcasses that they acquired. The results for tooth mark frequencies in the Leakey assemblage are almost always higher for sub-samples of the SC unit when compared with those reported for the LAS interval of the OGAP assemblage, while the frequencies of tooth marks in the clay unit are lower than those reported for the Lemuta interval of the OGAP assemblage. Like the results for percussion marks, they fall within similar sub-samples of the feeding trace models, and differences are likely the result of small sample sizes and collection bias in the Leakey assemblage.

The values for cut marks are similar in both stratigraphic units in showing higher proportions of cut marks on size 3-4 animals than on size 1-2 animals. This is consistent with results reported for the OGAP assemblage form HWK EE (Pante et al., this volume), but the values for size 1-2 fragments are higher in the OGAP assemblage. Cut mark values for size 34 animals in both stratigraphic units fall within or just below the $95 \%$ interquantile ranges of the H-C model, which simulates hominins having had primary access to flesh from carcasses. The ranges for size group 1-2 fragments all fall below the $\mathrm{H}-\mathrm{C}$ model, but the results for 
midshaft fragments from the clay unit are within the lower range of the $\mathrm{HO}$ and $\mathrm{WB}-\mathrm{C}$ models, both of which simulate primary access to flesh by hominins. Overall, the results suggest hominins had access to substantial amounts of flesh from carcasses at the site, especially from larger animals.

The bone surface modification results for the HWK EE Leakey fossil assemblage suggest that, while hominins broke the majority of limb bone to access marrow at the site, both hominins and carnivores shared access to flesh. These results are consistent with those reported for the HWK EE fossil assemblage collected by OGAP (Pante et al., this volume), from which more detailed interpretations are possible using the freshly excavated material. When the same methods are used, these results are also consistent with interpretations of hominin behavior based on the FLK Zinjanthropus assemblage (Pante et al., 2012; 2015, but see Domínguez-Rodrigo et al., 2014) in suggesting hominins likely scavenged much of their animal foods, but still had access to substantial amounts of flesh and marrow. Notably, sites associated with Homo erectus consistently show earlier access to carcasses than is inferred for the HWK EE hominins (Monahan, 1996; Pickering et al., 2004; Pobiner et al., 2008; Domínguez-Rodrigo et al. 2009b; Pante, 2013).

\section{Conclusions}

The HWK EE site represents an important time period of human evolution just prior to the appearance of Homo erectus and Acheulean technology at Olduvai Gorge. The substantial collection of well-preserved lithics and fossils recovered from the site by Mary Leakey over four decades ago revealed its potential to OGAP. Although it appears collection bias has affected both the lithic and fossil assemblages that she excavated, they both remain invaluable datasets for understanding the behavior of Oldowan hominins just prior to the Acheulean technological revolution at Olduvai Gorge. 
The HWK EE Leakey lithic assemblage is one of the largest reported for any Oldowan site. It is characterized by core-and-flake technology typical of the Oldowan with simple flaking techniques and minimal reduction of cores, which are abundant in the collection compared with the number of flakes and debitage. Retouched flake frequencies and battered tools are higher than those reported for Olduvai Bed I and Lower Bed II assemblages (Leakey, 1971; Proffitt, this volume; de la Torre and Mora, 2005), yet flaking schemes are poorly organized and rarely affect more than one area of a core.

The HWK EE Leakey fossil assemblage is taxonomically-rich and covered in the feeding traces of both hominins and carnivores. The proportion of specimens with percussion, tooth, and cut marks suggests the exploitation of carcass resources was maximized by both hominins and carnivores at the site. The nearby water source and open habitat at the site suggest it would have been highly competitive, and likely had a high risk of predation from both mammalian carnivores and crocodiles. Despite this risk, hominins were active at the site and typically had access to most or all bone marrow from carcasses, while likely having shared access to flesh with carnivores at the site. These interpretations are similar to those for the Bed I FLK Zinjanthropus assemblage, where hominins are inferred to have had access to most bone marrow, but only 50\% of flesh from carcasses (Pante et al., 2012; 2015; but see Domínguez-Rodrigo et al., 2014 for an alternative interpretation).

Our analysis of the HWK EE Leakey assemblage demonstrates the reward of revisiting material recovered long ago, but left mostly unstudied. This treasure, hidden for decades at Olduvai Gorge, led to renewed excavations at the site and allowed fresh inferences about the paleoenvironment, paleoecology and behavior of hominins at Olduvai Gorge (de la Torre et al, this volume; Pante et al, this volume; de la Torre and Mora, this volume; Rivals et al, this volume, Uno et al., this volume). The site may be one of the last associated with 
Homo habilis at Olduvai, and may ultimately reveal important clues about the conditions that led to the extinction of the species and emergence of Homo erectus.

\section{Acknowledgements}

Stone tool drawings by A. Theodoropoulou. We thank the staff from the National Museum of Nairobi and the Leakey camp at Olduvai Gorge, for their assistance. We wish to acknowledge the work done by conservators Renata Peters and Eri Ohara-Anderson in the curation of the fossil material. The analysis of the Leakey HWK EE collection was funded by the European Research Council-Starting Grants (283366) within the frame of the OGAP project, which is authorized by the Commission for Science and Technology (COSTECH), the Department of Antiquities, and the NCAA, Tanzania. 


\section{Figure captions}

Figure 1. A) Location of HWK EE in Olduvai Gorge (map template after Jorayev et al, 2016). B) The Leakey Trench at HWK EE, before beginning of excavations by OGAP in 2009. C) Aerial view of two OGAP trenches at HWK EE (T1-Main Trench and T27) and the estimated shape of Leakey's trench.

Figure 2. A) An excerpt of the HWK EE accession number catalogue archived in the National Museum of Nairobi. B) Tentative correlation between OGAP trenches (based on the stratigraphy by de la Torre et al, this volume) and Leakey's trench (based on the catalogue data). C-D) Absolute frequencies of stone tools and fossils (C) and unmodified material (D) from the Leakey collection per spit, based on the catalogue accession numbers.

Figure 3. A) Absolute frequencies of fossils and stone tools per lithological unit*, according to the Leakey catalogue and based on the assemblage curated in the Leakey camp. *Surface and unprovenanced material excluded. B) Relative frequency of provenanced lithic categories, according to Leakey's catalogue. C-D) Relative frequency of artefacts per raw material in the entire analysed assemblage (C), and according to general stone tool groups (D). E-F) Percentages of technological categories in the entire assemblage (E), and per unit (F).

Figure 4. Whole flake attributes in the entire HWK EE assemblage. A-B) Length classes of the whole assemblage (A), and per raw material (B). C) Types of striking platforms. D) Flake cortex percentages according to Toth's (1982) types. All data from Table 6.

Figure 5. A) Lava flakes. B-D) Chert (B-C) and lava (D) retouched artefacts.

Figure 6. Core attributes per stratigraphic unit and raw material group. A-B) Length class patterns. CD) Weight ranges. E-F) Number of removals. G-H) Cortex coverage.

Figure 7. Freehand knapping schemes in the entire HWK EE Leakey core assemblage (A), per stratigraphic unit (B) and per raw material (C). Abbreviations. TC: test core. USP: unifacial simple partial. USP2: unifacial simple partial on two independent planes. BSP: bifacial simple partial. UAU1: Unidirectional abrupt unifacial reduction on one knapping surface. UAU2: Unidirectional abrupt unifacial exploitation on two independent flaking surfaces. UAUT: Unifacial abrupt 
unidirectional total. UABI: Unifacial abrupt bidirectional. BAP: bifacial abrupt partial. BALP: bifacial alternating partial. BALT: bifacial alternating total. UP: Unifacial peripheral exploitation. BP: bifacial peripheral. BHC: Bifacial hierarchical centripetal. DISC: Discoid. POL: Polyhedral. MLT: Multifacial. See description of core reduction schemes in de la Torre (2011) and de la Torre and Mora (this volume).

Figure 8. HWK EE Leakey cores reduced following Unifacial Simple Partial (A) and Bifacial Simple Partial (B-F) knapping schemes.

Figure 9. Examples of Bifacial Alternating Partial (A-C), Multifacial (D) and Polyhedral (E-G) flaking schemes in the HWKEE Leakey core assemblage.

Figure 10. Unidirectional Abrupt Unifacial (A-B), Bifacial Abrupt Partial (C), Unifacial Peripheral (E), Bifacial Peripheral (D), and Bifacial Hierarchical Centripetal (F) flaking schemes in the HWKEE Leakey core assemblage.

Figure 11. Retouched artefacts of chert (A), quartzite (B), basalt (C), phonolite (D) and trachytetrachyandesite (E).

Figure 12) Length of limb bone midshaft fragments from the comparative samples of the sandy conglomerate (SC) and clay units compared with those from the feeding trace models CO, Carnivore only; HO, Hammerstone Only; H-C, Hammerstone-to-Carnivore.

Figure 13) Examples of well-preserved fossils from HWK EE. A) Mandible of Elephas recki from the SC unit; B) Mandible of Sivatherium cf. maurusium from the SC unit; C) Horn cores of Parmalarius angusticornis from the SC unit.

Figure 14) Bone surface modification on fossils from HWK EE. A) Percussion battering on size 3 bovid metacarpal from clay unit; B) Percussion pit on size 2 humerus near-epiphysis from clay unit; C) Tooth score on size 2 proximal ulna of a bovid from clay unit; D) Tooth puncture on size 4 distal humerus of a bovid from SC unit; E) cut mark on size 3 proximal femur of a bovid from the SC unit F) Cut mark on size 3 metacarpal midshaft of a bovid from the clay unit. 


\section{References cited}

Arroyo, A., Torre, de la I., This volume. Pounding tools in HWK EE and EF-HR (Olduvai Gorge, Tanzania): percussive activities in the Oldowan - Acheulean transition. J. Hum. Evol.

Behrensmeyer, A.K., 1975. The taphonomy and paleoecology of Plio-Pleistocene vertebrate assemblages east of Lake Rudolf, Kenya. Bulletin of the Museum of Comparative Zoology 146, 473-578.

Behrensmeyer, A.K., 1978. Taphonomic and ecologic information from bone weathering. Paleobiology 4, 150162.

Bibi, F., Pante, M.C., Boisserie, J., Werdelin, L., Fortelius, M., Hlusko, L., Njau, J., Stewart, K., Souron, A., Varela, S., de la Torre, I. Large Mammals and Fish from Middle Bed II, Olduvai, and the Paleoecology of the Serengeti. J. Hum Evol.

Blumenschine, R.J., 1995. Percussion marks, tooth marks, and experimental determinations of the timing of hominid and carnivore access to long bones at FLK Zinjanthropus, Olduvai Gorge, Tanzania. J. Hum. Evol. 29, 21-51.

Blumenschine, R.J., Marean, C.W., Capaldo, S.D., 1996. Blind tests of inter-analyst correspondence and accuracy in the identification of cut marks, percussion marks, and carnivore tooth marks on bone surfaces. J. Archaeol. Sci. 23, 493-507.

Blumenschine, R.J., Prassack, K.A., Kreger, D., Pante, M.C., 2007. Carnivore tooth marks, microbial bioerosion and the invalidation of Domínguez-Rodrigo and Barba's (2006) test of Oldowan hominin scavenging behavior. J. Hum. Evol. 53, 420-426.

Bunn, H.T., 1982. Meat-eating and human evolution: studies of the diet and subsistence patterns of Plio-Pleistocene hominids. Ph.D. dissertation, University of California, Berkeley. 
Capaldo, S.D., 1995. Inferring hominid and carnivore behavior from dual-patterned archaeofaunal assemblages. Ph.D. dissertation, Rutgers University

Chavaillon, J., 1979. Essai pour une typologie du matériel de percussion. Bulletin de la Societé Préhistorique Française 76, 230-233.

Domínguez-Rodrigo, M., de Juana, S., Galán, A.B., 2009a. A new protocol to differentiate trampling marks from butchery cut marks. J. Archaeol. Sci. 36, 2643-2654.

Domínguez-Rodrigo, M., Mabulla, A., Bunn, H.T., Barba, R., Diez-Martín, F., Egeland, C.P., Esílez, E., Egeland, A., Yravedra, J., Sáchez, P., 2009b. Unraveling hominin behavior at another anthropogenic site from Olduvai Gorge (Tanzania): new archaeological and taphonomic research at BK, Upper Bed II. J. Hum. Evol. 57, 260-283.

Domínguez-Rodrigo, M., Bunn, H.T., Yravedra, J., 2014. A critical re-evaluation of bone surface modification models for inferring fossil hominin and carnivore interactions through a multivariate approach: application to the FLK Zinj archaeofaunal assemblage (Olduvai Gorge, Tanzania). Quatern. Int. 322-323, 32-43.

Faith, J.T., 2007. Sources of variation in carnivore tooth-mark frequencies in a modern spotted hyena (Crocuta crocuta) den assemblage, Amboseli Park, Kenya. J. Archaeol. Sci. 34, 1601-1609.

Gentry, A.W., Gentry, A., 1978. Fossil Bovidae (Mammalia) of Olduvai Gorge, Tanzania. Part I. Bulletin of the British Museum, Geological Series 29, 289-446. Hay, R., 1976. The Geology of Olduvai Gorge. Clarendon Press, Oxford. Isaac, G. L., Harris, J. W. K. \& Kroll, E. M., 1997. The Stone Artifact Assemblages: A Comparative Study. In (G. L. Isaac, Ed.) Koobi Fora Research Project. Volume 5: PlioPleistocene Archaeology. Oxford: Oxford University Press, 262-362.

Jorayev, G., Wehr, K., Benito-Calvo, A., Njau, J. \& Torre, I. de la. (2016). Imaging and photogrammetry models of Olduvai Gorge (Tanzania) by Unmanned Aerial Vehicles: A 
high-resolution digital database for research and conservation of Early Stone Age sites. Journal of Archaeological Science 75, 40-56.

Leakey, M. D., 1971. Olduvai Gorge. Vol 3. Excavations in Beds I and II, 1960-1963. Cambridge: Cambridge University Press.

Leakey, M.D., Roe, D.A., 1994. Olduvai Gorge Vol 5. Excavations in Beds III and IV and the Masek Beds 1968-1971. Cambridge Univeristy Press, Cambridge.

Marean, C. W., Frey, C., 1997. Animal bones from caves to cities: reverse utility curves as methodological artifacts. Am. Antiq. 62, 698-716.

McHenry, L., Deino, A., This volume. 40Ar/39Ar dating and tephrochemistry of Bed II and above, Olduvai Gorge, Tanzania, and the chronology of the Oldowan-Acheulean transition. J. Hum. Evol.

Monahan, C.M., 1996. New zooarchaeological data from Bed II, Olduvai Gorge, Tanzania: implications for hominid behavior in the Early Pleistocene. J. Hum. Evol. 31, 93-128.

Mora, R., Torre, I. de la, 2005. Percussion tools in Olduvai Beds I and II (Tanzania): Implications for early human activities. Journal of Anthropological Archaeology 24, 179192.

Njau, J.K., Blumenschine, R.J., 2006. A diagnosis of crocodile feeding traces on larger mammal bone, with fossil examples from the Plio-Pleistocene Olduvai Basin, Tanzania. J. Hum. Evol. 50, 142-162.

Pante, M.C. 2010. The larger mammal fossil assemblages from Beds III and IV, Olduvai Gorge, Tanzania: Implications for the feeding behavior of Homo erectus. Ph.D. dissertation, Rutgers University.

Pante, M. C., 2013. The larger mammal fossil assemblage from JK2, Bed III, Olduvai Gorge, Tanzania: Implications for the feeding behavior of Homo erectus. J. Hum. Evol. 64, 6882. 
Pante, M.C., Blumenschine, R.J., Capaldo, S.D., Scott, R.S., 2012. Validation of bone surface modification models for inferring fossil hominin and carnivore feeding interactions, with reapplication to FLK 22, Olduvai Gorge, Tanzania. J. Hum. Evol. 63, 395-407.

Pante, M. C., Scott, R. S., Blumenschine, R. J., Capaldo, S. D., 2015. Revalidation of bone surface modification models for inferring fossil hominin and carnivore feeding interactions. Quatern. Int. 355(12), 164-168.

Pante, M.C., Njau, J.K., Hensley-Marschand, B., Keevil, T., Martín-Ramos, C., Peters, R. Torre, I. de la. This volume. The carnivorous feeding behavior of early Homo at HWK EE Bed II, Olduvai Gorge, Tanzania. J. Hum. Evol.

Pickering, T.R., Domínguez-Rodrigo, M., Egeland, C., Brain, C.K., 2004. New data and ideas on the foraging behaviour of Early Stone Age hominins at Swartkrans Cave, South Africa. S. Afr. J. Sci. 100, 215-219.

Pobiner, B.L., Roger, M.J., Monahan, C.M., Harris, J.W.K., 2008. New evidence for hominin carcass processing strategies at 1.5 Ma, Koobi Fora, Kenya. J. Hum. Evol. 55, 103-130.

Prassack, K., Pante, M.C., Njau, J.K., Torre, I. de la, This volume. The Paleoecology of Fossil Birds from Middle Bed II, at Olduvai Gorge, Tanzania. J. Hum. Evol.

Proffitt, T. this volume. Is there a Developed Oldowan A at Olduvai Gorge? A diachronic analysis of the Oldowan and DOA transition at Olduvai Gorge, Tanzania. J. Hum. Evol.

Rivals, F. Uno, K., Bibi, F., Pante, M.C., Njau, J.K., Torre, de la I. This volume. Dietary traits of the ungulates from the HWK EE site at Olduvai Gorge (Tanzania): Diachronic changes and seasonality. J. Hum Evol.

Shipman, P., Rose, J., 1983. Early hominid hunting, butchering and carcass processing behaviors: approaches to the fossil record. J. Anth. Archaeol 2, 57-98. 
Torre, I. de la, 2011. The Early Stone Age lithic assemblages of Gadeb (Ethiopia) and the Developed Oldowan / early Acheulean in East Africa. Journal of Human Evolution 60, 768-812.

Torre, I. de la, Mora, R., 2005. Technological Strategies in the Lower Pleistocene at Olduvai Beds I \& II. Liege: ERAUL 112.

Torre, I. de la, Mora, R. This volume. Technological strategies of the late Oldowan at Olduvai Gorge: The HWKEE lithic assemblage. J. Hum. Evol.

Torre, I. de la, Benito-Calvo, A., Arroyo, A., Zupancich, A., Proffitt, T., 2013. Experimental protocols for the study of battered stone anvils from Olduvai Gorge (Tanzania). J. of Archaeol. Sci. 40, 313-332.

Torre, I. de la, Albert, R.M., Arroyo, A., Macphail, R., McHenry, L., Mora, R., Njau, J.K., Pante, M.C., Rivera Rondón, C., Rodríguez-Cintas, A., Stanistreet, I., Stollhofen, H., Wehr, K. New excavations at the HWK EE site: archaeology, palaeo-environment and site formation processes in the basal part of Middle Bed II (Olduvai Gorge, Tanzania). J. Hum. Evol. In review.

Torre, I. de la, Albert, R.M., Macphail, R., McHenry, L., Pante, M.C., Rodríguez-Cintas, A., Stanistreet, I., Stollhofen, H. (this volume, 'b') The contexts and early Acheulean archaeology of the EF-HR paleo-landscape (Olduvai Gorge, Tanzania). J. Hum. Evol. In review.

Toth, N., 1982. The Stone Technologies of Early Hominids at Koobi Fora, Kenya; An Experimental Approach. Unpublished Ph. D., Berkeley, University of California.

Uno, K., Rivals, F., Bibi, F., Pante, M.C., Njau, J.K., Torre, de la I. (this volume) Large mammal diets and paleoecology across the Oldowan-Acheulean transition at Olduvai Gorge, Tanzania from stable isotope and tooth wear analyses. J. Hum. Evol. 
Voorhies, M., 1969. Taphonomy and population dynamics of an Early Pliocene vertebrate fauna, Knox County Nebraska. University of Wyoming Contributions 
Table 1) Breakdown of HWK EE tool types and unmodified material according to Leakey's catalogue. Surface and unprovenanced material excluded.

\begin{tabular}{|c|c|c|c|c|c|c|c|}
\hline \multirow{4}{*}{$\begin{array}{l}\text { General category } \\
\text { Detached }\end{array}$} & \multirow{4}{*}{$\begin{array}{l}\text { Leakey's classification } \\
\text { Debitage } \\
\text { Fragment }\end{array}$} & \multicolumn{2}{|c|}{ CLAY } & \multicolumn{2}{|l|}{$\mathrm{SC}$} & \multicolumn{2}{|c|}{ Total } \\
\hline & & $\mathrm{n}$ & $\%$ & $\mathrm{n}$ & $\%$ & \multicolumn{2}{|c|}{$\mathrm{n}$} \\
\hline & & 98 & 21.4 & 250 & 8.3 & 348 & 10.0 \\
\hline & & 31 & 6.8 & 176 & 5.8 & 207 & 5.9 \\
\hline \multicolumn{2}{|l|}{ Detached Total } & 129 & 28.2 & 426 & 14.1 & 555 & 15.9 \\
\hline \multirow[t]{6}{*}{ Flaked } & Chopper & 40 & 8.8 & 318 & 10.5 & 358 & 10.3 \\
\hline & Core & 8 & 1.8 & 42 & 1.4 & 50 & 1.4 \\
\hline & Discoid & 5 & 1.1 & 27 & 0.9 & 32 & 0.9 \\
\hline & Polyhedron & 10 & 2.2 & 30 & 1.0 & 40 & 1.1 \\
\hline & Protobiface & 3 & 0.7 & 8 & 0.3 & 11 & 0.3 \\
\hline & Retouched tool & 14 & 3.1 & 59 & 1.9 & 73 & 2.1 \\
\hline \multicolumn{2}{|l|}{ Flaked Total } & 80 & 17.5 & 484 & 16.0 & 564 & 16.2 \\
\hline \multirow[t]{5}{*}{ Pounded } & Anvil & 6 & 1.3 & 6 & 0.2 & 12 & 0.3 \\
\hline & Hammerstone & 4 & 0.9 & 30 & 1.0 & 34 & 1.0 \\
\hline & Subspheroid/spheroid & 18 & 3.9 & 94 & 3.1 & 112 & 3.2 \\
\hline & Battered block/ cobble & 3 & 0.7 & 42 & 1.4 & 45 & 1.3 \\
\hline & Utilised block/ cobble/ pebble & 21 & 4.6 & 89 & 2.9 & 110 & 3.2 \\
\hline \multicolumn{2}{|l|}{ Pounded Total } & 52 & 11.4 & 261 & 8.6 & 313 & 9.0 \\
\hline \multicolumn{2}{|l|}{ Unmodified Total } & 196 & 42.9 & 1859 & 61.4 & 2055 & 58.9 \\
\hline \multicolumn{2}{|l|}{ Grand Total } & 457 & 100 & 3030 & 100 & 3487 & 100 \\
\hline
\end{tabular}


Table 2) Raw material breakdown of HWK EE stone tools and unmodified lithics, according to Leakey's catalogue. Surface and unprovenanced material excluded.

\begin{tabular}{|c|c|c|c|c|c|c|c|c|c|c|c|c|c|c|c|c|c|c|}
\hline & \multicolumn{6}{|c|}{ Clay } & \multicolumn{6}{|c|}{$\mathrm{SC}$} & \multicolumn{6}{|c|}{ Combined assemblage } \\
\hline & \multicolumn{2}{|c|}{ Stone tool } & \multicolumn{2}{|c|}{ Unmodified } & \multicolumn{2}{|c|}{ Total } & \multicolumn{2}{|c|}{ Stone tool } & \multicolumn{2}{|c|}{ Unmodified } & \multicolumn{2}{|c|}{ Total } & \multicolumn{2}{|c|}{ Stone tool } & \multicolumn{2}{|c|}{ Unmodified } & \multicolumn{2}{|c|}{ Total } \\
\hline & $\mathrm{n}$ & $\%$ & $\mathrm{n}$ & $\%$ & $\mathrm{n}$ & $\%$ & $\mathrm{n}$ & $\%$ & $n$ & $\%$ & $\mathrm{n}$ & $\%$ & $\mathrm{n}$ & $\%$ & $\mathrm{n}$ & $\%$ & $\mathrm{n}$ & $\%$ \\
\hline Phonolite & 22 & 9.8 & 45 & 23.3 & 67 & 16.1 & 259 & 23.5 & 526 & 28.5 & 785 & 26.6 & 281 & 21.2 & 571 & 28.0 & 852 & 25.3 \\
\hline Trachyte & & 0.0 & 9 & 4.7 & 9 & 2.2 & 2 & 0.2 & 2 & 0.1 & 4 & 0.1 & 2 & 0.2 & 11 & 0.5 & 13 & 0.4 \\
\hline Basalt & 6 & 2.7 & 31 & 16.1 & 37 & 8.9 & 19 & 1.7 & 34 & 1.8 & 53 & 1.8 & 25 & 1.9 & 65 & 3.2 & 90 & 2.7 \\
\hline Unspecified lava & 24 & 10.7 & 95 & 49.2 & 119 & 28.5 & 250 & 22.7 & 1201 & 65.0 & 1451 & 49.2 & 274 & 20.7 & 1296 & 63.5 & 1570 & 46.7 \\
\hline Chert & 5 & 2.2 & & 0.0 & 5 & 1.2 & 21 & 1.9 & 1 & 0.1 & 22 & 0.7 & 26 & 2.0 & 1 & 0.0 & 27 & 0.8 \\
\hline Quartzite & 166 & 74.1 & 13 & 6.7 & 179 & 42.9 & 529 & 48.1 & 69 & 3.7 & 598 & 20.3 & 695 & 52.5 & 82 & 4.0 & 777 & 23.1 \\
\hline Feldspar & & 0.0 & & 0.0 & & 0.0 & 7 & 0.6 & & 0.0 & 7 & 0.2 & 7 & 0.5 & 0 & 0.0 & 7 & 0.2 \\
\hline Gneiss & 1 & 0.4 & & 0.0 & 1 & 0.2 & 8 & 0.7 & 6 & 0.3 & 14 & 0.5 & 9 & 0.7 & 6 & 0.3 & 15 & 0.4 \\
\hline Obsidian & & 0.0 & & 0.0 & & 0.0 & 1 & 0.1 & 1 & 0.1 & 2 & 0.1 & 1 & 0.1 & 1 & 0.0 & 2 & 0.1 \\
\hline Tuff & & 0.0 & & 0.0 & & 0.0 & 4 & 0.4 & 8 & 0.4 & 12 & 0.4 & 4 & 0.3 & 8 & 0.4 & 12 & 0.4 \\
\hline Grand Total & 224 & 100.0 & 193 & 100.00 & 417 & 100.0 & 1100 & 100.0 & 1848 & 100.00 & 2948 & 100.0 & 1324 & 100.0 & 2041 & 100.0 & 3365 & 100.0 \\
\hline
\end{tabular}


Table 3) Technological categories of the analyzed HWK EE lithic assemblage.

\begin{tabular}{|c|c|c|c|c|c|c|c|c|c|}
\hline & & \multicolumn{2}{|c|}{ Clay } & \multicolumn{2}{|c|}{$\mathrm{SC}$} & \multicolumn{2}{|c|}{ Clay/ SC* } & \multicolumn{2}{|c|}{ Entire assemblage } \\
\hline & & $\mathrm{n}$ & $\%$ & $\mathrm{n}$ & $\%$ & $\mathrm{n}$ & $\%$ & $\mathrm{n}$ & $\%$ \\
\hline \multirow{5}{*}{$\begin{array}{l}\text { Detached } \\
22.4 \mathrm{~kg}\end{array}$} & Flake & 105 & 14.1 & 221 & 11.2 & 19 & 14.0 & 345 & 12.1 \\
\hline & Flake Frag & 303 & 40.6 & 575 & 29.2 & 58 & 42.6 & 936 & 32.9 \\
\hline & Shatter $<20 \mathrm{~mm}$ & 125 & 16.7 & 271 & 13.8 & 25 & 18.4 & 421 & 14.8 \\
\hline & Shatter $>20 \mathrm{~mm}$ & 63 & 8.4 & 224 & 11.4 & 22 & 16.2 & 309 & 10.8 \\
\hline & Detached total & 596 & 79.8 & 1291 & 65.7 & 124 & 91.2 & 2011 & 70.6 \\
\hline \multirow{6}{*}{$\begin{array}{l}\text { Flaked } \\
180 \mathrm{~kg}\end{array}$} & Core & 113 & 15.1 & 522 & 26.6 & 7 & 5.1 & 642 & 22.5 \\
\hline & Core Frag & 8 & 1.1 & 28 & 1.4 & & 0.0 & 36 & 1.3 \\
\hline & Retouched tool & 16 & 2.1 & 47 & 2.4 & 4 & 2.9 & 67 & 2.4 \\
\hline & Retouched tool Frag & 1 & 0.1 & & 0.0 & & 0.0 & 1 & 0.0 \\
\hline & Split Cobble & 1 & 0.1 & 2 & 0.1 & & 0.0 & 3 & 0.1 \\
\hline & Flaked total & 139 & 18.6 & 599 & 30.5 & 11 & 8.1 & 749 & 26.3 \\
\hline \multirow{7}{*}{$\begin{array}{l}\text { Pounded } \\
27.5 \mathrm{~kg}\end{array}$} & Anvil & 1 & 0.1 & & & & & 1 & 0.0 \\
\hline & Pitted stones & 1 & 0.1 & 2 & 0.1 & & & 3 & 0.1 \\
\hline & Knapping hammerstone & 7 & 0.9 & 46 & 2.3 & 1 & 0.7 & 54 & 1.9 \\
\hline & Knapping hammer frag & 1 & 0.1 & 15 & 0.8 & & & 16 & 0.6 \\
\hline & Subspheroid & & & 7 & 0.4 & & & 7 & 0.2 \\
\hline & Other pounded pieces & 2 & 0.3 & 6 & 0.3 & & & 8 & 0.3 \\
\hline & Pounded total & 12 & 1.6 & 76 & 3.9 & 1 & 0.7 & 89 & 3.1 \\
\hline $\begin{array}{l}\text { Total } \\
230 \mathrm{~kg}\end{array}$ & Entire assemblage & 747 & 100.0 & 1966 & 100.0 & 136 & 100.0 & 2849 & 100.0 \\
\hline
\end{tabular}

* Artifacts with unclear attribution to either SC or clay units. 
Table 4) Raw material distribution per general stone tool groups and stratigraphic unit.

\begin{tabular}{|c|c|c|c|c|c|c|c|c|c|c|c|c|c|c|}
\hline & \multicolumn{3}{|c|}{ Clay } & \multicolumn{3}{|c|}{$\mathrm{SC}$} & \multicolumn{3}{|c|}{ Clay/SC } & \multicolumn{5}{|c|}{ Entire assemblage } \\
\hline & Detached & Flaked & Pounded & Detached & Flaked & Pounded & Detached & Flaked & Pounded & Detached & Flaked & Pounded & Total & $\%$ \\
\hline Phonolite & 18 & 26 & 4 & 42 & 176 & 20 & 4 & 1 & & 64 & 203 & 24 & 291 & 10.2 \\
\hline $\mathrm{T}-\mathrm{Ta}$ & 1 & 9 & 2 & 5 & 52 & 15 & & & & 6 & 61 & 17 & 84 & 2.9 \\
\hline Basalt & 7 & 22 & 2 & 26 & 113 & 16 & 5 & 4 & 1 & 38 & 139 & 19 & 196 & 6.9 \\
\hline Chert & 2 & 3 & & 32 & 29 & & 13 & 4 & & 47 & 36 & 0 & 83 & 2.9 \\
\hline Quartzite & 567 & 79 & 4 & 1182 & 224 & 25 & 102 & 2 & & 1851 & 305 & 29 & 2185 & 76.7 \\
\hline Quartz & & & & 2 & & & & & & 2 & & & 2 & 0.1 \\
\hline Feldspar & & & & & 3 & & & & & & 3 & & 3 & 0.1 \\
\hline Pegmatite & & & & 1 & & & & & & 1 & & & 1 & 0.0 \\
\hline Gneiss & 1 & & & 1 & 2 & & & & & 2 & 2 & & 4 & 0.1 \\
\hline Total & 596 & 139 & 12 & 1291 & 599 & 76 & 124 & 11 & 1 & 2011 & 749 & 89 & 2849 & 100.0 \\
\hline
\end{tabular}


Table 5) Dimensions of significant technological categories in the HWK EE lithic assemblage.

\begin{tabular}{|c|c|c|c|c|c|c|}
\hline & Category & & Mean & Max & Min & Std Dev \\
\hline \multirow{4}{*}{ Detached } & \multirow{4}{*}{$\begin{array}{l}\text { Whole flake } \\
\mathrm{n}=344\end{array}$} & Length & 38.6 & 102.0 & 17.0 & 15.5 \\
\hline & & Width & 29.4 & 85.0 & 12.0 & 12.8 \\
\hline & & Thickness & 14.0 & 46.0 & 2.0 & 7.3 \\
\hline & & Weight & 28.6 & 332.4 & 0.7 & 45.5 \\
\hline \multirow{12}{*}{ Flaked } & \multirow{4}{*}{$\begin{array}{l}\text { Core } \\
n=642\end{array}$} & Length & 71.2 & 172.0 & 25.0 & 18.9 \\
\hline & & Width & 57.5 & 101.0 & 20.0 & 15.7 \\
\hline & & Thickness & 43.9 & 91.0 & 7.0 & 13.8 \\
\hline & & Weight & 268.1 & 2123.6 & 4.2 & 207.9 \\
\hline & \multirow{4}{*}{$\begin{array}{l}\text { Split Cobble } \\
n=3\end{array}$} & Length & 85.7 & 89.0 & 80.0 & 4.9 \\
\hline & & Width & 67.7 & 78.0 & 56.0 & 11.1 \\
\hline & & Thickness & 36.3 & 39.0 & 33.0 & 3.1 \\
\hline & & Weight & 259.3 & 297.4 & 230.0 & 34.6 \\
\hline & \multirow{4}{*}{$\begin{array}{l}\text { Retouched tool } \\
n=67\end{array}$} & Length & 45.9 & 104.0 & 19.0 & 19.5 \\
\hline & & Width & 35.0 & 69.0 & 15.0 & 13.8 \\
\hline & & Thickness & 16.6 & 43.0 & 5.0 & 7.7 \\
\hline & & Weight & 43.4 & 237.2 & 1.6 & 50.5 \\
\hline \multirow{16}{*}{ Pounded } & \multirow{4}{*}{$\begin{array}{l}\text { Anvil } \\
\mathrm{n}=1\end{array}$} & Length & 117.0 & 117.0 & 117.0 & 0.0 \\
\hline & & Width & 83.0 & 83.0 & 83.0 & 0.0 \\
\hline & & Thickness & 52.0 & 52.0 & 52.0 & 0.0 \\
\hline & & Weight & 831.7 & 831.7 & 831.7 & 0.0 \\
\hline & \multirow{4}{*}{$\begin{array}{l}\text { Pitted stone } \\
\mathrm{n}=3\end{array}$} & Length & 84.7 & 93.0 & 74.0 & 9.7 \\
\hline & & Width & 69.0 & 80.0 & 53.0 & 14.2 \\
\hline & & Thickness & 48.0 & 61.0 & 37.0 & 12.1 \\
\hline & & Weight & 437.5 & 701.0 & 205.2 & 249.4 \\
\hline & \multirow{4}{*}{$\begin{array}{l}\text { Knapping hamm. } \\
\mathrm{n}=54\end{array}$} & Length & 73.1 & 121.0 & 44.0 & 14.1 \\
\hline & & Width & 59.8 & 85.0 & 35.0 & 10.8 \\
\hline & & Thickness & 46.3 & 67.0 & 25.0 & 9.7 \\
\hline & & Weight & 290.0 & 753.2 & 83.3 & 148.3 \\
\hline & \multirow{4}{*}{$\begin{array}{l}\text { Subspheroid } \\
\mathrm{n}=7\end{array}$} & Length & 65.6 & 75.0 & 53.0 & 7.5 \\
\hline & & Width & 58.6 & 68.0 & 46.0 & 8.6 \\
\hline & & Thickness & 53.6 & 64.0 & 39.0 & 9.8 \\
\hline & & Weight & 290.1 & 438.2 & 132.7 & 110.2 \\
\hline
\end{tabular}


Table 6) Attributes of the whole flakes in the HWK EE assemblage.

\begin{tabular}{|c|c|c|c|c|c|c|c|c|c|}
\hline & & \multicolumn{2}{|c|}{ Lava } & \multicolumn{2}{|c|}{ Metamorphic } & \multicolumn{2}{|c|}{ Chert } & \multicolumn{2}{|c|}{ Total } \\
\hline & & $\mathrm{n}$ & $\%$ & $\mathrm{n}$ & $\%$ & $\mathrm{n}$ & $\%$ & $\mathrm{n}$ & $\%$ \\
\hline \multirow{7}{*}{ Length classes } & $<20 \mathrm{~mm}$ & & 0.0 & 9 & 3.2 & 4 & 28.6 & 13 & 3.8 \\
\hline & $20-39 \mathrm{~mm}$ & 9 & 17.3 & 176 & 63.1 & 8 & 57.1 & 193 & 55.9 \\
\hline & $40-59 \mathrm{~mm}$ & 28 & 53.8 & 69 & 24.7 & 2 & 14.3 & 99 & 28.7 \\
\hline & $60-79 \mathrm{~mm}$ & 12 & 23.1 & 22 & 7.9 & & 0.0 & 34 & 9.9 \\
\hline & $80-99 \mathrm{~mm}$ & 2 & 3.8 & 3 & 1.1 & & 0.0 & 5 & 1.4 \\
\hline & $>100$ & 1 & 1.9 & & 0.0 & & 0.0 & 1 & 0.3 \\
\hline & Total & 52 & 100.0 & 279 & 100.0 & 14 & 100.0 & 345 & 100.0 \\
\hline \multirow{5}{*}{ Striking platform preparation } & Non-facetted & 18 & 40.0 & 60 & 22.4 & 3 & 27.3 & 81 & 25.0 \\
\hline & Unifacetted & 24 & 53.3 & 202 & 75.4 & 7 & 63.6 & 233 & 71.9 \\
\hline & Bifacetted & 2 & 4.4 & 5 & 1.9 & 1 & 9.1 & 8 & 2.5 \\
\hline & Multifacetted & 1 & 2.2 & 1 & 0.4 & & 0.0 & 2 & 0.6 \\
\hline & Total & 45 & 100.0 & 268 & 100.0 & 11 & 100.0 & 324 & 100.0 \\
\hline \multirow{3}{*}{ Cortex striking platform } & Cortical & 18 & 40.0 & 60 & 22.5 & 3 & 27.3 & 81 & 25.1 \\
\hline & Non-cortical & 27 & 60.0 & 207 & 77.5 & 8 & 72.7 & 242 & 74.9 \\
\hline & Total & 45 & 100.0 & 267 & 100.0 & 11 & 100.0 & 323 & 100.0 \\
\hline \multirow{5}{*}{ Cortex dorsal side } & Cortical & 2 & 4.4 & 4 & 1.5 & 2 & 15.4 & 8 & 2.4 \\
\hline & Cortex $>50 \%$ & 20 & 44.4 & 17 & 6.3 & 1 & 7.7 & 38 & 11.5 \\
\hline & Cortex $<50 \%$ & 12 & 26.7 & 62 & 22.8 & 9 & 69.2 & 83 & 25.2 \\
\hline & Non-cortical & 11 & 24.4 & 189 & 69.5 & 1 & 7.7 & 201 & 60.9 \\
\hline & Total & 45 & 100.0 & 272 & 100.0 & 13 & 100.0 & 330 & 100.0 \\
\hline \multirow{7}{*}{ Toth's flake types } & I & & 0.0 & 2 & 0.8 & 1 & 9.1 & 3 & 0.9 \\
\hline & II & 14 & 31.1 & 22 & 8.3 & 2 & 18.2 & 38 & 11.8 \\
\hline & III & 4 & 8.9 & 36 & 13.5 & & 0.0 & 40 & 12.4 \\
\hline & IV & 2 & 4.4 & 2 & 0.8 & & 0.0 & 4 & 1.2 \\
\hline & $\mathrm{V}$ & 18 & 40.0 & 55 & 20.7 & 7 & 63.6 & 80 & 24.8 \\
\hline & VI & 7 & 15.6 & 149 & 56.0 & 1 & 9.1 & 157 & 48.8 \\
\hline & Grand Total & 45 & 100.0 & 266 & 100.0 & 11 & 100.0 & 322 & 100.0 \\
\hline
\end{tabular}


Table 7) Attributes of the complete cores in the HWK EE assemblage.

\begin{tabular}{|c|c|c|c|c|c|c|c|c|c|c|c|c|c|c|c|}
\hline & \multicolumn{8}{|c|}{ Raw material } & \multicolumn{6}{|c|}{ Stratigraphic position } \\
\hline & & \multicolumn{2}{|c|}{ Lava } & \multicolumn{2}{|c|}{ Metamorphic } & \multicolumn{2}{|c|}{ Chert } & \multicolumn{2}{|c|}{ Total } & \multicolumn{2}{|c|}{ Clay } & \multicolumn{2}{|c|}{ SC } & \multicolumn{2}{|c|}{ Total } \\
\hline & & $\mathrm{n}$ & $\%$ & $\mathrm{n}$ & $\%$ & $\mathrm{n}$ & $\%$ & $\mathrm{n}$ & $\%$ & $\mathrm{n}$ & $\%$ & $\mathrm{n}$ & $\%$ & $\mathrm{n}$ & $\%$ \\
\hline \multirow{6}{*}{ Length class } & $20-39 \mathrm{~mm}$ & 1 & 0.3 & 36 & 14.8 & 6 & 30.0 & 43 & 6.7 & 8 & 7.1 & 34 & 6.5 & 42 & 6.6 \\
\hline & $40-59 \mathrm{~mm}$ & 21 & 5.6 & 96 & 39.3 & 5 & 25.0 & 122 & 19.0 & 21 & 18.6 & 100 & 19.2 & 121 & 19.1 \\
\hline & $60-79 \mathrm{~mm}$ & 164 & 43.4 & 73 & 29.9 & 9 & 45.0 & 246 & 38.3 & 42 & 37.2 & 203 & 38.9 & 245 & 38.6 \\
\hline & $80-99 \mathrm{~mm}$ & 174 & 46.0 & 27 & 11.1 & & 0.0 & 201 & 31.3 & 30 & 26.5 & 167 & 32.0 & 197 & 31.0 \\
\hline & $>100 \mathrm{~mm}$ & 18 & 4.8 & 12 & 4.9 & & 0.0 & 30 & 4.7 & 12 & 10.6 & 18 & 3.4 & 30 & 4.7 \\
\hline & Grand Total & 378 & 100.0 & 244 & 100.0 & 20 & 100.0 & 642 & 100.0 & 113 & 100.0 & 522 & 100.0 & 635 & 100.0 \\
\hline \multirow{7}{*}{ Weight class } & $<50 \mathrm{~g}$ & 4 & 1.1 & 45 & 18.4 & 6 & 30.0 & 55 & 8.6 & 12 & 10.6 & 42 & 8.0 & 54 & 8.5 \\
\hline & $50-100 \mathrm{~g}$ & 6 & 1.6 & 57 & 23.4 & 4 & 20.0 & 67 & 10.4 & 9 & 8.0 & 57 & 10.9 & 66 & 10.4 \\
\hline & $101-200 \mathrm{~g}$ & 68 & 18.0 & 77 & 31.6 & 8 & 40.0 & 153 & 23.8 & 26 & 23.0 & 127 & 24.3 & 153 & 24.1 \\
\hline & $201-400 \mathrm{~g}$ & 202 & 53.4 & 40 & 16.4 & 2 & 10.0 & 244 & 38.0 & 37 & 32.7 & 204 & 39.1 & 241 & 38.0 \\
\hline & $401-800 \mathrm{~g}$ & 93 & 24.6 & 14 & 5.7 & & 0.0 & 107 & 16.7 & 19 & 16.8 & 86 & 16.5 & 105 & 16.5 \\
\hline & $>800 \mathrm{~g}$ & 5 & 1.3 & 11 & 4.5 & & 0.0 & 16 & 2.5 & 10 & 8.8 & 6 & 1.1 & 16 & 2.5 \\
\hline & Grand Total & 378 & 100.0 & 244 & 100.0 & 20 & 100.0 & 642 & 100.0 & 113 & 100.0 & 522 & 100.0 & 635 & 100.0 \\
\hline \multirow{4}{*}{ Cortex } & Cortex $>50 \%$ & 253 & 75.3 & 57 & 33.1 & 9 & 47.4 & 319 & 60.5 & 49 & 51.0 & 266 & 62.7 & 315 & 60.6 \\
\hline & Cortex $<50 \%$ & 82 & 24.4 & 95 & 55.2 & 10 & 52.6 & 187 & 35.5 & 40 & 41.7 & 144 & 34.0 & 184 & 35.4 \\
\hline & Non-cortical & 1 & 0.3 & 20 & 11.6 & & 0.0 & 21 & 4.0 & 7 & 7.3 & 14 & 3.3 & 21 & 4.0 \\
\hline & Grand Total & 336 & 100.0 & 172 & 100.0 & 19 & 100.0 & 527 & 100.0 & 96 & 100.0 & 424 & 100.0 & 520 & 100.0 \\
\hline \multirow{7}{*}{ Blank } & Cobble & 333 & 91.5 & 13 & 6.3 & 1 & 5.6 & 347 & 58.8 & 52 & 51.0 & 290 & 60.3 & 342 & 58.7 \\
\hline & Block & & 0.0 & 83 & 39.9 & & 0.0 & 83 & 14.1 & 24 & 23.5 & 59 & 12.3 & 83 & 14.2 \\
\hline & Nodule & & 0.0 & & 0.0 & 14 & 77.8 & 14 & 2.4 & 1 & 1.0 & 12 & 2.5 & 13 & 2.2 \\
\hline & Fragment & 19 & 5.2 & 105 & 50.5 & 2 & 11.1 & 126 & 21.4 & 21 & 20.6 & 104 & 21.6 & 125 & 21.4 \\
\hline & Split Cobble & 8 & 2.2 & & 0.0 & & 0.0 & 8 & 1.4 & 1 & 1.0 & 7 & 1.5 & 8 & 1.4 \\
\hline & Flake & 4 & 1.1 & 7 & 3.4 & 1 & 5.6 & 12 & 2.0 & 3 & 2.9 & 9 & 1.9 & 12 & 2.1 \\
\hline & Grand Total & 364 & 100.0 & 208 & 100.0 & 18 & 100.0 & 590 & 100.0 & 102 & 100.0 & 481 & 100.0 & 583 & 100.0 \\
\hline \multirow{5}{*}{ Scars } & 1-3 scars & 154 & 43.9 & 45 & 29.0 & 4 & 23.5 & 203 & 38.8 & 37 & 37.4 & 162 & 38.9 & 199 & 38.6 \\
\hline & 4-6 scars & 151 & 43.0 & 80 & 51.6 & 10 & 58.8 & 241 & 46.1 & 46 & 46.5 & 192 & 46.2 & 238 & 46.2 \\
\hline & 7-9 scars & 42 & 12.0 & 28 & 18.1 & 2 & 11.8 & 72 & 13.8 & 14 & 14.1 & 57 & 13.7 & 71 & 13.8 \\
\hline & $>9$ & 4 & 1.1 & 2 & 1.3 & 1 & 5.9 & 7 & 1.3 & 2 & 2.0 & 5 & 1.2 & 7 & 1.4 \\
\hline & Grand Total & 351 & 100.0 & 155 & 100.0 & 17 & 100.0 & 523 & 100.0 & 99 & 100.0 & 416 & 100.0 & 515 & 100.0 \\
\hline
\end{tabular}




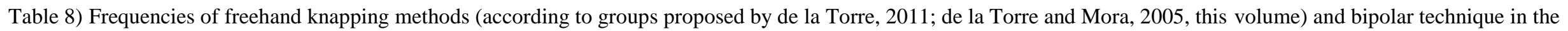
HWK EE Leakey collection.

\begin{tabular}{|c|c|c|c|c|c|c|c|c|c|c|c|c|c|c|}
\hline & \multicolumn{8}{|c|}{ Raw material } & \multicolumn{6}{|c|}{ Stratigraphic unit* } \\
\hline & $\mathrm{N}$ & $\%$ & $\mathrm{~N}$ & $\%$ & $\mathrm{~N}$ & $\%$ & $\mathrm{~N}$ & $\%$ & $\mathrm{n}$ & $\%$ & $\mathrm{n}$ & $\%$ & $\mathrm{n}$ & $\%$ \\
\hline USP & 64 & 17.3 & 13 & 5.6 & & 0.0 & 77 & 12.4 & 11 & 10.0 & 66 & 13.1 & 77 & 12.5 \\
\hline USP2 & 9 & 2.4 & 3 & 1.3 & 1 & 5.0 & 13 & 2.1 & 3 & 2.7 & 10 & 2.0 & 13 & 2.1 \\
\hline UAU1 & 26 & 7.0 & 23 & 9.9 & 1 & 5.0 & 50 & 8.0 & 9 & 8.2 & 41 & 8.1 & 50 & 8.1 \\
\hline UAU2 & 2 & 0.5 & 11 & 4.7 & & 0.0 & 13 & 2.1 & 2 & 1.8 & 11 & 2.2 & 13 & 2.1 \\
\hline UAUT & & 0.0 & 2 & 0.9 & 1 & 5.0 & 3 & 0.5 & & 0.0 & 3 & 0.6 & 3 & 0.5 \\
\hline UABI & 1 & 0.3 & & 0.0 & & 0.0 & 1 & 0.2 & 1 & 0.9 & & 0.0 & 1 & 0.2 \\
\hline UP & 3 & 0.8 & 3 & 1.3 & 1 & 5.0 & 7 & 1.1 & 2 & 1.8 & 5 & 1.0 & 7 & 1.1 \\
\hline $\mathrm{BP}$ & 13 & 3.5 & 18 & 7.8 & 1 & 5.0 & 32 & 5.1 & 9 & 8.2 & 22 & 4.4 & 31 & 5.0 \\
\hline $\mathrm{BHC}$ & & 0.0 & 4 & 1.7 & & 0.0 & 4 & 0.6 & 1 & 0.9 & 3 & 0.6 & 4 & 0.7 \\
\hline DISC & & 0.0 & 1 & 0.4 & & 0.0 & 1 & 0.2 & & 0.0 & & 0.0 & & 0.0 \\
\hline POL & 2 & 0.5 & 7 & 3.0 & & 0.0 & 9 & 1.4 & 2 & 1.8 & 7 & 1.4 & 9 & 1.5 \\
\hline MLT & 28 & 7.6 & 31 & 13.4 & 4 & 20.0 & 63 & 10.1 & 17 & 15.5 & 46 & 9.1 & 63 & 10.2 \\
\hline BIPO & 5 & 1.4 & 24 & 10.3 & & 0.0 & 29 & 4.7 & 9 & 8.2 & 20 & 4.0 & 29 & 4.7 \\
\hline Total frequency & 370 & 100.0 & 232 & 100.0 & 20 & 100.0 & 622 & 100.0 & 110 & 100.0 & 505 & 100.0 & 615 & 100.0 \\
\hline Total weight $(\mathrm{kg})$ & 122.1 & & 47.8 & & 2.1 & & 172.1 & & 35.1 & & 134.6 & & 170.1 & \\
\hline
\end{tabular}

*Cores without specific stratigraphic attribution excluded. 
Table 9) NISP of mammal fossils for all HWK EE Leakey assemblage.

\begin{tabular}{lrrr}
\hline Stratigraphic Unit & NISP Bones & NISP Teeth & Total \\
\hline SC & 380 & 102 & 482 \\
Clay & 746 & 154 & 900 \\
Total & 1126 & 256 & 1382 \\
\hline
\end{tabular}

Does not include surface specimens or specimens that could not be associated with either the clay or SC units.

Table 10) NISP for limb bones in the comparative samples

\begin{tabular}{llrr}
\hline & & \multicolumn{3}{c}{ Comparative } \\
& & $\begin{array}{c}\text { Midshaft } \\
\text { fragments }\end{array}$ \\
\hline \multirow{2}{*}{ SC } & Size 1-2 & All limb bones & 4 \\
& Size 3-4 & 19 & 25 \\
Clay & Size 1-2 & 47 & 65 \\
& Size 3-4 & 106 & 40 \\
& & 68 & 134 \\
\hline
\end{tabular}


Table 11) Minimum number of individuals by stratigraphic unit

\begin{tabular}{|c|c|c|c|}
\hline & & $\mathrm{SC}$ & Clay \\
\hline \multirow{5}{*}{ Bovidae } & Alcelaphini & 7 & 12 \\
\hline & Antilopini & 1 & 4 \\
\hline & Hippotragini & 1 & 1 \\
\hline & Reduncini & 1 & 1 \\
\hline & Tragelaphini & 0 & 1 \\
\hline \multirow{2}{*}{ Carnivora } & Indet. & 1 & 1 \\
\hline & Crocuta cf. C. ultra & 1 & 0 \\
\hline Cercopithecidae & Theropithecus cf. oswaldi & 1 & 0 \\
\hline Crocodylidae & Crocodylus sp. & 1 & 1 \\
\hline \multirow{2}{*}{ Equidae } & Equus cf. oldowayensis & 2 & 4 \\
\hline & Eurygnathohippus cf. cornelianus & 1 & 1 \\
\hline \multirow{2}{*}{ Giraffidae } & Giraffa sp. & 1 & 1 \\
\hline & Sivatherium cf. maurusium & 2 & 0 \\
\hline Hippopotamidae & Hippopotamus cf. gorgops & 0 & 1 \\
\hline Rhinocerotidae & Ceratotherium cf. simum & 0 & 1 \\
\hline \multirow{2}{*}{ Proboscidea } & Deinotherium sp. & 1 & 0 \\
\hline & Elephas recki & 1 & 0 \\
\hline \multirow{4}{*}{ Suidae } & Kolpochoerus majus & 0 & 1 \\
\hline & Kolpochoerus limnetes & 0 & 1 \\
\hline & Kolpochoerus sp. & 0 & 1 \\
\hline & Metridiochoerus cf. compactus & 1 & 0 \\
\hline Total & & 23 & 32 \\
\hline
\end{tabular}


Table 12) NISP and MNE for the HWK EE Leakey assemblage

\begin{tabular}{|c|c|c|c|c|c|c|c|c|c|c|c|c|c|c|c|c|c|c|c|c|c|c|c|c|c|c|c|c|c|c|}
\hline \multirow{2}{*}{$\begin{array}{l}\text { Skeletal Parts } \\
\text { Cranial fragment }\end{array}$} & \multicolumn{2}{|c|}{ Size 1} & \multicolumn{2}{|c|}{ Size 2} & \multicolumn{2}{|c|}{ Size 3} & $\begin{array}{r}\text { SC } \\
\text { Size } \\
\text { NISP }\end{array}$ & & $\begin{array}{c}\text { Size } \\
\text { NISP }\end{array}$ & & $\begin{array}{r}\text { Size } \\
\text { NISP }\end{array}$ & $\begin{array}{l}\text { e } 6 \\
\text { MNE }\end{array}$ & $\begin{array}{l}\text { Tote } \\
\text { NISP }\end{array}$ & & $\begin{array}{r}\text { Size } \\
\text { NISP }\end{array}$ & & $\begin{array}{l}\text { Size } \\
\text { NISP }\end{array}$ & & $\begin{array}{c}\text { Size } \\
\text { NISP }\end{array}$ & & $\begin{array}{r}\text { CLAY } \\
\text { Size } 4 \\
\text { NISP }\end{array}$ & $\begin{array}{l}\text { AY } \\
\text { e4 } \\
\text { MNE }\end{array}$ & $\begin{array}{c}\text { Size } \\
\text { NISP }\end{array}$ & $\begin{array}{l}\text { ze } 5 \\
\text { MNE }\end{array}$ & & $\begin{array}{l}\text { e } 6 \\
\text { MNE }\end{array}$ & $\begin{array}{l}\text { Totala } \\
\text { NISP }\end{array}$ & & $\begin{array}{l}\text { HWK } \\
\text { Grand } \\
\text { NISP }\end{array}$ & \\
\hline & 1 & & 1 & & 4 & & 0 & & 0 & & 0 & & 6 & & 3 & & 13 & & 13 & & & & 0 & & 0 & & & & & \\
\hline Frontal & 0 & 0 & 0 & 0 & 1 & 1 & 0 & 0 & 0 & 0 & 0 & 0 & 1 & & 0 & 0 & 1 & 1 & 1 & 1 & 0 & 0 & 0 & 0 & 0 & 0 & 2 & & 3 & 3 \\
\hline Horn core & 10 & 9 & 7 & 7 & 6 & 6 & 0 & 0 & 0 & 0 & 0 & 0 & 23 & 22 & 5 & 3 & 6 & 4 & 3 & 2 & 0 & 0 & 0 & 0 & 0 & 0 & 14 & 9 & 37 & 31 \\
\hline Hyoid & 0 & 0 & 0 & 0 & 0 & 0 & 0 & 0 & 0 & 0 & 0 & 0 & 0 & 0 & 0 & 0 & 0 & 0 & 0 & 0 & 0 & 0 & 0 & 0 & 0 & 0 & 0 & 0 & 0 & 0 \\
\hline Maxilla & 0 & 0 & 0 & 0 & 1 & 1 & 0 & 0 & 0 & 0 & 0 & 0 & 1 & 1 & 0 & 0 & 4 & 1 & 5 & 2 & 0 & 0 & 0 & 0 & 0 & 0 & 9 & 3 & 10 & 4 \\
\hline Mandible & 0 & 0 & 1 & 1 & 4 & 3 & 0 & 0 & 3 & 2 & 0 & 0 & 8 & 6 & 7 & 3 & 12 & 2 & 13 & 4 & 0 & 0 & 0 & 0 & 0 & 0 & 32 & 9 & 40 & 15 \\
\hline Nasal & 0 & 0 & 0 & 0 & 0 & 0 & 0 & 0 & 0 & 0 & 0 & 0 & 0 & 0 & 0 & 0 & 0 & 0 & 0 & 0 & 0 & 0 & 0 & 0 & 0 & 0 & 0 & 0 & 0 & 0 \\
\hline Occipital & 0 & 0 & 1 & 1 & 0 & 0 & 0 & 0 & 0 & 0 & 0 & 0 & 1 & 1 & 0 & 0 & 1 & 1 & 0 & 0 & 0 & 0 & 0 & 0 & 0 & 0 & 1 & 1 & 2 & 2 \\
\hline Premaxilla & 0 & 0 & 1 & 1 & 1 & 1 & 0 & 0 & 0 & 0 & 0 & 0 & 2 & 2 & 0 & 0 & 0 & 0 & 0 & 0 & 0 & 0 & 0 & 0 & 0 & 0 & 0 & 0 & 2 & 2 \\
\hline Sphenoid & 0 & 0 & 0 & 0 & 0 & 0 & 0 & 0 & 0 & 0 & 0 & 0 & 0 & 0 & 0 & 0 & 0 & 0 & 0 & 0 & 0 & 0 & 0 & 0 & 0 & 0 & 0 & 0 & 0 & 0 \\
\hline $\begin{array}{l}\text { Temporal } \\
\text { Tyomotic }\end{array}$ & 0 & 0 & 0 & 0 & 0 & 0 & 0 & 0 & 0 & 0 & 0 & 0 & 0 & 0 & 0 & 0 & 3 & 2 & 1 & 1 & 0 & 0 & 0 & 0 & 0 & 0 & 4 & 3 & 4 & 3 \\
\hline $\begin{array}{l}\text { Zygomatic } \\
\text { Cranial total }\end{array}$ & 0 & $\begin{array}{l}0 \\
9\end{array}$ & 1 & 1 & 0 & 0 & 0 & 0 & 0 & 0 & 0 & 0 & 1 & $\begin{array}{c}1 \\
31\end{array}$ & 0 & 0 & $2^{2}$ & 2 & 0 & 0 & 0 & 0 & 0 & 0 & 0 & 0 & 2 & 2 & 3 & 3 \\
\hline $\begin{array}{l}\text { Cranala total } \\
\text { Atlas }\end{array}$ & $\begin{array}{c}11 \\
0\end{array}$ & $\begin{array}{l}9 \\
0\end{array}$ & 12 & $\begin{array}{l}11 \\
11\end{array}$ & $\begin{array}{r}17 \\
3\end{array}$ & 12 & $\begin{array}{l}0 \\
0\end{array}$ & $\begin{array}{l}0 \\
0 \\
0\end{array}$ & $\begin{array}{l}3 \\
0 \\
0\end{array}$ & $\begin{array}{l}2 \\
0\end{array}$ & $\begin{array}{l}0 \\
0\end{array}$ & $\begin{array}{l}0 \\
0 \\
0\end{array}$ & $\begin{array}{r}43 \\
4\end{array}$ & $\begin{array}{r}34 \\
4\end{array}$ & $\begin{array}{c}15 \\
0\end{array}$ & $\begin{array}{l}6 \\
0\end{array}$ & 42 & 13 & 36 & $\begin{array}{r}10 \\
10\end{array}$ & 0 & 0 & 0 & & & & 93 & 29 & 136 & 63 \\
\hline Axis & 0 & 0 & 0 & 0 & 2 & 2 & 0 & 0 & 0 & 0 & 0 & 0 & 2 & $\begin{array}{l}4 \\
2\end{array}$ & 0 & 0 & $\begin{array}{l}1 \\
0\end{array}$ & $\begin{array}{l}1 \\
0\end{array}$ & 1 & 0 & 0 & 0 & 0 & 0 & 0 & 0 & 0 & $\begin{array}{l}2 \\
0\end{array}$ & $\begin{array}{l}0 \\
2 \\
2\end{array}$ & $\begin{array}{l}6 \\
2\end{array}$ \\
\hline Caudal vertebra & 0 & 0 & 0 & 0 & 0 & 0 & 0 & 0 & 0 & 0 & 0 & 0 & 0 & 0 & 1 & 1 & 5 & 5 & 0 & 0 & 0 & 0 & 0 & 0 & 0 & 0 & 6 & 6 & 6 & 6 \\
\hline Cervical vertebra & 0 & 0 & 0 & 0 & 6 & 6 & 0 & 0 & 0 & 0 & 0 & 0 & 6 & 6 & 0 & 0 & 3 & 1 & 9 & 4 & 0 & 0 & 0 & 0 & 0 & 0 & 12 & 5 & 18 & 11 \\
\hline Clavicle & 0 & 0 & 0 & 0 & 0 & 0 & 0 & 0 & 0 & 0 & 0 & 0 & 0 & 0 & 0 & 0 & 0 & 0 & 0 & 0 & 0 & 0 & 0 & 0 & 0 & 0 & 0 & 0 & 0 & 0 \\
\hline Lumbar vertebra & 2 & 2 & 2 & 2 & 0 & 0 & 0 & 0 & 0 & 0 & 0 & 0 & 4 & 4 & 1 & 1 & 7 & 5 & 3 & 2 & 0 & 0 & 0 & 0 & 0 & 0 & 11 & 8 & 15 & 12 \\
\hline Rib & 1 & 1 & 5 & 2 & 10 & 2 & 0 & 0 & 1 & 1 & 0 & 0 & 17 & 6 & 9 & 5 & 18 & 5 & 26 & 5 & 5 & 1 & 2 & 1 & 0 & 0 & 60 & 17 & 77 & 23 \\
\hline Rib 1 & 0 & 0 & 0 & 0 & 0 & 0 & 0 & 0 & 0 & 0 & 0 & 0 & 0 & 0 & 0 & 0 & 0 & 0 & 0 & 0 & 0 & 0 & 0 & 0 & 0 & 0 & 0 & 0 & 0 & 0 \\
\hline Sacrum & 0 & 0 & 1 & 1 & 0 & 0 & 0 & 0 & 0 & 0 & 0 & 0 & 1 & 1 & 0 & 0 & 1 & 1 & 0 & 0 & 0 & 0 & 0 & 0 & 0 & 0 & 1 & 1 & 2 & 2 \\
\hline Sternum & 0 & 0 & 0 & 0 & 0 & 0 & 0 & 0 & 0 & 0 & 0 & 0 & 0 & 0 & 0 & 0 & 0 & 0 & 0 & 0 & 0 & 0 & 0 & 0 & 0 & 0 & 0 & 0 & 0 & 0 \\
\hline Thoracic vertebra & 2 & 2 & 6 & 5 & 3 & 3 & 0 & 0 & 0 & 0 & 1 & 1 & 12 & 11 & 5 & 5 & 6 & 3 & 8 & 5 & 0 & 0 & 0 & 0 & 0 & 0 & 19 & 13 & 31 & 24 \\
\hline Vertebra fragment & 1 & 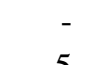 & 0 & - & 0 & - & 0 & - & 0 & - & 0 & - & 1 & -1 & 1 & - & 1 & - & 1 & - & 0 & - & 0 & & 0 & & 3 & & 4 & \\
\hline $\begin{array}{l}\text { Axial total } \\
\text { Femur }\end{array}$ & 6 & 5 & $\begin{array}{c}15 \\
8\end{array}$ & 11 & 24 & 16 & 0 & 0 & 1 & 1 & 1 & 1 & 47 & 34 & 17 & 12 & 42 & 21 & 48 & 17 & 5 & 1 & 2 & 1 & 0 & 0 & 114 & 52 & 161 & 86 \\
\hline $\begin{array}{l}\text { Femur } \\
\text { Fibula }\end{array}$ & $\begin{array}{l}2 \\
0\end{array}$ & $\begin{array}{l}2 \\
0\end{array}$ & $\begin{array}{l}8 \\
0\end{array}$ & $\begin{array}{l}3 \\
0\end{array}$ & $\begin{array}{r}11 \\
0\end{array}$ & $\begin{array}{l}3 \\
0\end{array}$ & 0 & 等 & 0 & $\begin{array}{l}0 \\
0\end{array}$ & $\begin{array}{l}0 \\
0\end{array}$ & o & $\begin{array}{r}21 \\
0\end{array}$ & $\begin{array}{l}8 \\
0\end{array}$ & $\begin{array}{l}4 \\
0\end{array}$ & $\begin{array}{l}1 \\
0\end{array}$ & $\begin{array}{r}13 \\
0\end{array}$ & $\begin{array}{l}3 \\
0\end{array}$ & $\begin{array}{l}8 \\
0\end{array}$ & $\begin{array}{l}3 \\
0\end{array}$ & $\begin{array}{l}0 \\
0\end{array}$ & $\begin{array}{l}0 \\
0\end{array}$ & $\begin{array}{l}1 \\
0\end{array}$ & $\begin{array}{l}1 \\
0\end{array}$ & $\begin{array}{l}0 \\
0\end{array}$ & $\begin{array}{l}0 \\
0\end{array}$ & 26 & $\begin{array}{l}8 \\
0\end{array}$ & 47 & 16 \\
\hline Humerus & 0 & 0 & 4 & 3 & 3 & 1 & 1 & 1 & 1 & 1 & 0 & 0 & 9 & 6 & 1 & 1 & 12 & 3 & 7 & 3 & 0 & 0 & 0 & 0 & 0 & 0 & 20 & 7 & 29 & 13 \\
\hline Long bone fragments & 3 & & 13 & & 17 & & 2 & & 7 & & 0 & & 42 & & 9 & & 50 & & 28 & & 0 & & 0 & & 0 & & 87 & & 129 & \\
\hline Metacarpal & 0 & 0 & 1 & 1 & 5 & 2 & 0 & 0 & 1 & 1 & 0 & 0 & 7 & 4 & 5 & 2 & 11 & 2 & 12 & 4 & 0 & 0 & 1 & 1 & 0 & 0 & 29 & 9 & 36 & 13 \\
\hline Metapodial & 1 & & 7 & & 3 & & 0 & & 0 & & 0 & - & 11 & & 4 & & 7 & & 15 & & 0 & & 0 & & 0 & & 26 & & 37 & \\
\hline Metatarsal & 0 & 0 & 4 & 2 & 6 & 4 & 1 & 1 & 2 & 2 & 0 & 0 & 13 & 9 & 4 & 3 & 9 & 2 & 17 & 4 & 2 & 1 & 1 & 1 & 0 & 0 & 33 & 11 & 46 & 20 \\
\hline Radius & 1 & 1 & 2 & 1 & 4 & 3 & 2 & 2 & 1 & 1 & 0 & 0 & 10 & 8 & 4 & 2 & 14 & 2 & 11 & 5 & 0 & 0 & 0 & 0 & 0 & 0 & 29 & 9 & 39 & 17 \\
\hline Tibia & 0 & 0 & 2 & 2 & 19 & 6 & 0 & 0 & 1 & 1 & 0 & 0 & 22 & 9 & 8 & 7 & 23 & 3 & 15 & 7 & 0 & 0 & 0 & 0 & 0 & 0 & 46 & 17 & 68 & 26 \\
\hline Ulna & 0 & 0 & 0 & 0 & 3 & 3 & 1 & 1 & 0 & 0 & 0 & 0 & 4 & 4 & 3 & 2 & 5 & 2 & 4 & 2 & 0 & 0 & 0 & 0 & 0 & 0 & 12 & 6 & 16 & 10 \\
\hline Appendicular total & 7 & 3 & 41 & 12 & 71 & 22 & 7 & 5 & 13 & 6 & 0 & 0 & 139 & 48 & 42 & 18 & 144 & 17 & 117 & 28 & 2 & 1 & 3 & 3 & 0 & 0 & 308 & 67 & 447 & 115 \\
\hline Astragalus & 1 & 1 & 1 & 1 & 5 & 5 & 1 & 1 & 0 & 0 & 0 & 0 & 8 & 8 & 3 & 3 & 1 & 1 & 0 & 0 & 0 & 0 & 0 & 0 & 0 & 0 & 4 & 4 & 12 & 12 \\
\hline Calcaneus & 0 & 0 & 2 & 2 & 4 & 4 & 1 & 1 & 0 & 0 & 0 & 0 & 7 & 7 & 4 & 0 & 0 & 0 & 0 & 0 & 0 & 0 & 0 & 0 & 0 & 0 & 4 & 0 & 11 & 7 \\
\hline $\begin{array}{l}\text { Carpal or tarsal } \\
\text { Cuneiform }\end{array}$ & $\begin{array}{l}0 \\
0\end{array}$ & 0 & $\begin{array}{l}1 \\
0\end{array}$ & 0 & $\begin{array}{l}1 \\
0\end{array}$ & 0 & $\begin{array}{l}1 \\
0\end{array}$ & 0 & $\begin{array}{l}1 \\
0\end{array}$ & $\begin{array}{l}1 \\
0\end{array}$ & $\begin{array}{l}0 \\
0\end{array}$ & 0 & $\begin{array}{l}4 \\
0\end{array}$ & 0 & $\frac{1}{2}$ & 2 & $\begin{array}{l}4 \\
1\end{array}$ & 1 & $\begin{array}{l}2 \\
2\end{array}$ & 2 & $\begin{array}{l}0 \\
0\end{array}$ & 0 & $\begin{array}{l}1 \\
0\end{array}$ & 0 & $\begin{array}{l}0 \\
0\end{array}$ & 0 & $\begin{array}{l}8 \\
5\end{array}$ & 5 & $\begin{array}{c}12 \\
5\end{array}$ & 5 \\
\hline & 0 & 0 & 1 & 1 & 1 & 1 & 0 & & 0 & 0 & 0 & & 2 & & & & & & & 0 & & & 0 & 0 & 0 & & & 6 & & 8 \\
\hline External-medial cuneiform & 2 & 2 & 1 & 1 & 3 & 3 & 0 & 0 & 0 & 0 & 0 & 0 & 6 & 6 & 0 & & & & & 0 & & 0 & 0 & 0 & 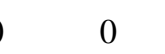 & & & 1 & 7 & 7 \\
\hline Lunate & 0 & 0 & 1 & 1 & 0 & 0 & 0 & 0 & 1 & 1 & 0 & 0 & 2 & 2 & & & & & & 0 & & 0 & 0 & 0 & 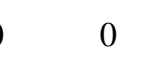 & & & 0 & 2 & 2 \\
\hline & 1 & 1 & 0 & 0 & 3 & 3 & 0 & & 0 & 0 & 0 & & 4 & & & & & & & & & 0 & & 0 & & & & & & 6 \\
\hline Navic & 0 & 0 & 2 & 2 & 1 & 1 & 0 & $c$ & 1 & 1 & 0 & & 4 & & & & & & & 0 & & 0 & 0 & 0 & & & & 3 & 7 & 7 \\
\hline Patella & 0 & 0 & 1 & 1 & 3 & 3 & 0 & 0 & 0 & 0 & 0 & 0 & & & & 0 & 3 & 3 & & 1 & & 0 & 0 & 0 & 0 & & & 4 & 8 & 8 \\
\hline & 1 & 1 & 5 & 4 & 8 & 7 & 0 & 0 & 0 & 0 & 0 & 0 & 14 & 12 & & 4 & 11 & 10 & 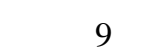 & 8 & & 0 & 0 & 0 & 0 & & 24 & 22 & 38 & 34 \\
\hline Phalan! & 5 & 5 & 4 & 4 & 7 & 7 & 0 & 0 & 0 & 0 & 0 & 0 & 16 & 16 & & & 2 & 1 & 5 & 5 & & 0 & 0 & 0 & 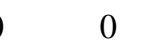 & & 13 & 12 & 29 & 28 \\
\hline Phalange distal & 3 & 3 & 2 & 1 & 3 & 3 & 0 & 0 & 2 & 2 & 0 & 0 & 10 & 9 & 3 & 3 & 2 & 2 & 0 & 0 & 0 & 0 & 0 & 0 & 0 & 0 & 5 & 5 & 15 & 14 \\
\hline e fragment & 1 & & 2 & & 0 & & 0 & & 0 & & 0 & & 3 & & 0 & & 1 & & 1 & & 0 & & 0 & & 0 & & 2 & & 5 & \\
\hline & 0 & 0 & 1 & 1 & 1 & 1 & 0 & 0 & 0 & 0 & 0 & 0 & 2 & 2 & & 0 & & 1 & & 0 & & 0 & 0 & 0 & 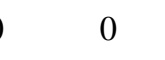 & & & 1 & 3 & 3 \\
\hline & 1 & 1 & 6 & 6 & 1 & 1 & 0 & 0 & & 0 & & & 8 & 8 & & & & & & & & & 0 & 0 & & & & 2 & 10 & 10 \\
\hline & 0 & 0 & 1 & 1 & 0 & 0 & 1 & 1 & & & 0 & & 3 & 3 & & & & & & & & & & & & & & 3 & 6 & 6 \\
\hline & 0 & 0 & 0 & 0 & 0 & 0 & 0 & $c$ & 0 & 0 & & & 0 & 0 & $c$ & ( & 0 & 0 & & 0 & & & & & 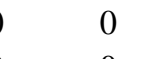 & & 0 & 0 & 0 & 0 \\
\hline & 0 & 0 & ( & & & 1 & 0 & & 0 & 0 & & & 1 & 1 & & & 1 & & 0 & 0 & & 0 & & 0 & 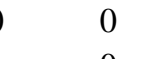 & & 1 & 1 & 2 & 2 \\
\hline Compact & 15 & 14 & 31 & 26 & 42 & 40 & 4 & 3 & 6 & 6 & 0 & 0 & 98 & 88 & 29 & 24 & 37 & 30 & 20 & 16 & 0 & 0 & 2 & 1 & 0 & 0 & 88 & 71 & 186 & 159 \\
\hline Innominate & 1 & 1 & 3 & 2 & 3 & 2 & 0 & 0 & 0 & 0 & 0 & 0 & 7 & 5 & 4 & 2 & 4 & 1 & 7 & 2 & 0 & 0 & 0 & 0 & 0 & 0 & 15 & 5 & 22 & 10 \\
\hline $\begin{array}{l}\text { Scapula } \\
\text { Delvis/scanula tota }\end{array}$ & 0 & 0 & 3 & 1 & 5 & 2 & 2 & 1 & 0 & 0 & 0 & 0 & 10 & 4 & 2 & 1 & 10 & 3 & 10 & 5 & 0 & 0 & 0 & 0 & 0 & 0 & 22 & ${ }^{9}$ & 32 & 13 \\
\hline $\begin{array}{l}\text { Pelvis/scapula total } \\
\text { TotaI Identified }\end{array}$ & $\begin{array}{r}1 \\
40\end{array}$ & $\begin{array}{r}1 \\
32\end{array}$ & $\begin{array}{r}6 \\
105\end{array}$ & $\begin{array}{c}3 \\
63\end{array}$ & $\begin{array}{r}8 \\
162\end{array}$ & $\begin{array}{r}4 \\
94\end{array}$ & $\begin{array}{r}2 \\
13\end{array}$ & $\frac{1}{9}$ & $\begin{array}{r}0 \\
23\end{array}$ & $\begin{array}{r}0 \\
15\end{array}$ & $\begin{array}{l}0 \\
1\end{array}$ & $\begin{array}{l}0 \\
1\end{array}$ & $\begin{array}{r}17 \\
344\end{array}$ & $\begin{array}{r}9 \\
213\end{array}$ & $\begin{array}{r}6 \\
109\end{array}$ & $\begin{array}{c}3 \\
63 \\
\end{array}$ & $\begin{array}{r}14 \\
279\end{array}$ & $\begin{array}{c}4 \\
85\end{array}$ & $\begin{array}{r}17 \\
238\end{array}$ & $\begin{array}{r}7 \\
78\end{array}$ & $\begin{array}{l}0 \\
7\end{array}$ & $\begin{array}{l}0 \\
2\end{array}$ & $\begin{array}{l}0 \\
7\end{array}$ & $\begin{array}{l}0 \\
5\end{array}$ & $\begin{array}{l}0 \\
0\end{array}$ & $\begin{array}{l}0 \\
0\end{array}$ & $\begin{array}{r}37 \\
640\end{array}$ & $\begin{array}{c}14 \\
233\end{array}$ & $\begin{array}{c}54 \\
984\end{array}$ & $\begin{array}{c}23 \\
446\end{array}$ \\
\hline $\begin{array}{l}\text { Total Identified } \\
\text { Indeterminate Mammal Frags }\end{array}$ & & & & & & & & & & & & & 344 & & & & & & & & & & & & & & $\begin{array}{l}640 \\
106\end{array}$ & 233 & $\begin{array}{l}984 \\
142\end{array}$ & 446 \\
\hline Grand Total & 40 & 32 & 105 & 63 & 162 & 94 & 13 & 9 & 23 & 15 & 1 & & 380 & 213 & 109 & 63 & 279 & 85 & 238 & 78 & 7 & 2 & 7 & 5 & 0 & 0 & 746 & 233 & 1126 & 446 \\
\hline
\end{tabular}

NISP; Number of individual specimens, MNE; Minimum number of elements. Size groups based on Bunn, 1982. 
Table 13) Weathering stage and general surface condition of fossil in the HWK EE Leakey assemblage

\begin{tabular}{llrr}
\hline & & SC & Clay \\
\hline & $0-1$ & 82.8 & 83.0 \\
Weathering stage $\%$ & 2 & 12.6 & 14.5 \\
& 3 & 4.3 & 2.3 \\
& 4 & 0.3 & 0.3 \\
& 5 & 0.0 & 25.6 \\
Surface condition \% & Major Exfoliation & 12.6 & 12.1 \\
& Major Rounding & 1.9 & 2.0 \\
& Major Adhering Matrix & 69.4 & 74.5 \\
\hline
\end{tabular}


Table 14) Incidences of bone surface modification for the HWK EE Leakey comparative assemblage and the feeding trace models

\begin{tabular}{|c|c|c|c|c|c|c|c|c|c|c|c|c|c|c|c|c|}
\hline \multirow{2}{*}{$\begin{array}{l}\text { Mark } \\
\text { Type }\end{array}$} & \multirow{2}{*}{$\begin{array}{l}\text { Animal } \\
\text { Size }\end{array}$} & \multirow[t]{2}{*}{ Statistics } & \multicolumn{6}{|c|}{ All Limb Bone Fragments } & \multicolumn{8}{|c|}{ Midshaft Fragments } \\
\hline & & & $\mathrm{CO}$ & $\mathrm{HO}$ & WB-C & $\mathrm{H}-\mathrm{C}$ & $\mathrm{V}-\mathrm{H}-\mathrm{C}$ & $\mathrm{SC}$ & Clay & $\mathrm{CO}$ & $\mathrm{HO}$ & WB-C & $\mathrm{H}-\mathrm{C}$ & V-H-C & SC & Clay \\
\hline \multirow{4}{*}{ Percussion } & \multirow{2}{*}{ Size 1-2 } & Mean $\%$ & - & 36.6 & - & 30.3 & 17.5 & 21.1 & 20.8 & - & 26.7 & - & 29.4 & 23.6 & 0 & 23.1 \\
\hline & & $95 \%$ I.Q.R & - & $26.3-46.2$ & - & $24.3-36.6$ & 4.4-34.8 & - & - & - & $14.0-37.8$ & - & $23.6-35.8$ & $5.9-47.1$ & - & - \\
\hline & \multirow{2}{*}{ Size 3-4 } & Mean $\%$ & - & 49.9 & - & 18.0 & 26.9 & 17.1 & 20.6 & - & 33.5 & - & 14.6 & 19.2 & 12 & 27.5 \\
\hline & & 95\% I.Q.R & - & $29.1-70.8$ & - & $11.5-25.5$ & 7.7-49.1 & - & - & - & 11.3-60.0 & - & $8.1-22.4$ & 3.7-38.3 & - & - \\
\hline \multirow{4}{*}{ Tooth } & \multirow{2}{*}{ Size $1-2$} & Mean $\%$ & 70.9 & - & 70.6 & 19.1 & 43.4 & 42.1 & 33.1 & 69.1 & - & 70.5 & 14.5 & 35.5 & 0 & 24.6 \\
\hline & & 95\% I.Q.R & $56.7-82.5$ & - & $55.7-84.3$ & $14.9-23.7$ & 21.7-65.2 & - & - & $54.8-81.0$ & - & $56.1-84.7$ & $10.5-18.9$ & $11.8-58.8$ & - & - \\
\hline & \multirow{2}{*}{ Size 3-4 } & Mean $\%$ & 87.6 & - & 78.9 & 24.9 & 18.5 & 38.3 & 35.9 & 86.5 & - & 57.3 & 14.8 & 5.6 & 28 & 30 \\
\hline & & 95\% I.Q.R & 77.9-95.5 & - & $61.9-95.0$ & 19.6-30.3 & $9.1-28.7$ & - & - & $75.7-95.8$ & - & 18.1-89.8 & $7.3-23.5$ & $0-14.4$ & - & - \\
\hline \multirow{4}{*}{ Cut } & \multirow{2}{*}{ Size 1-2 } & Mean $\%$ & - & 27.2 & 18.4 & 18.9 & 0 & 5.2 & 2.8 & - & 10.3 & 16.4 & 15.4 & 0 & 0 & 3.1 \\
\hline & & 95\% I.Q.R & - & $20.3-33.7$ & $5.5-34.8$ & $14.4-24.4$ & 0 & - & - & - & $3.1-17.6$ & $2.5-36.0$ & $10.9-20.6$ & 0 & - & - \\
\hline & \multirow{2}{*}{ Size 3-4 } & Mean \% & - & 45.9 & 41.9 & 16.8 & 8.5 & 12.8 & 11.8 & - & 20.1 & 40.0 & 12.2 & 0 & 8 & 15 \\
\hline & & 95\% I.Q.R & - & $25.0-66.7$ & $22.1-69.5$ & $12.1-21.9$ & $0-18.4$ & - & - & - & $0-40.0$ & $13.0-80.1$ & 7.9-16.9 & 0 & - & \\
\hline
\end{tabular}

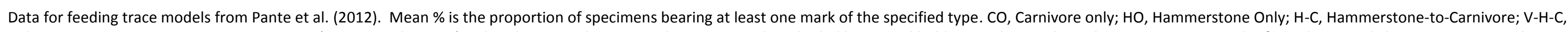

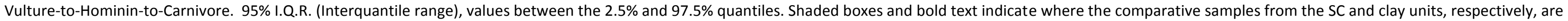
within the $95 \%$ interquantile ranges and therefore, statistically indistinguishable from the models. 
Figure 1

Click here to download high resolution image
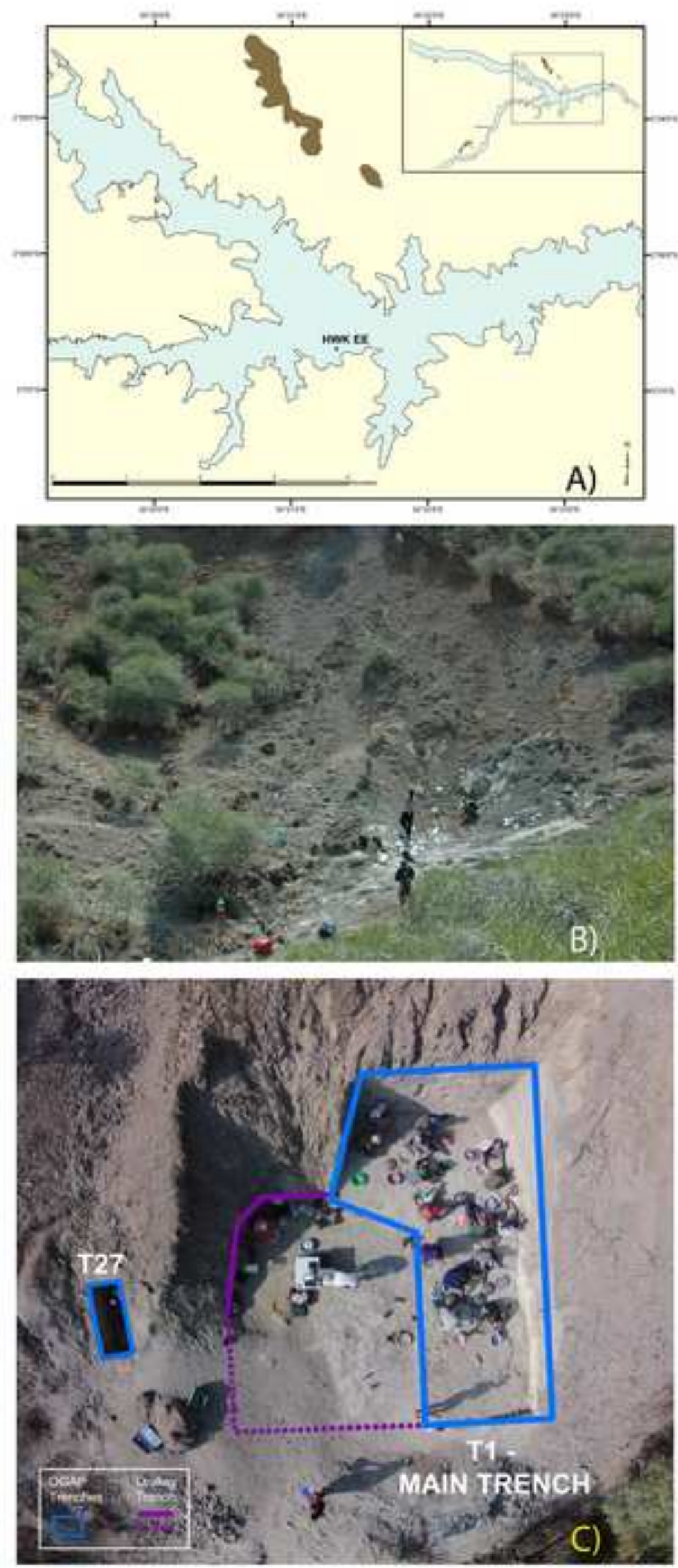
Click here to download high resolution image

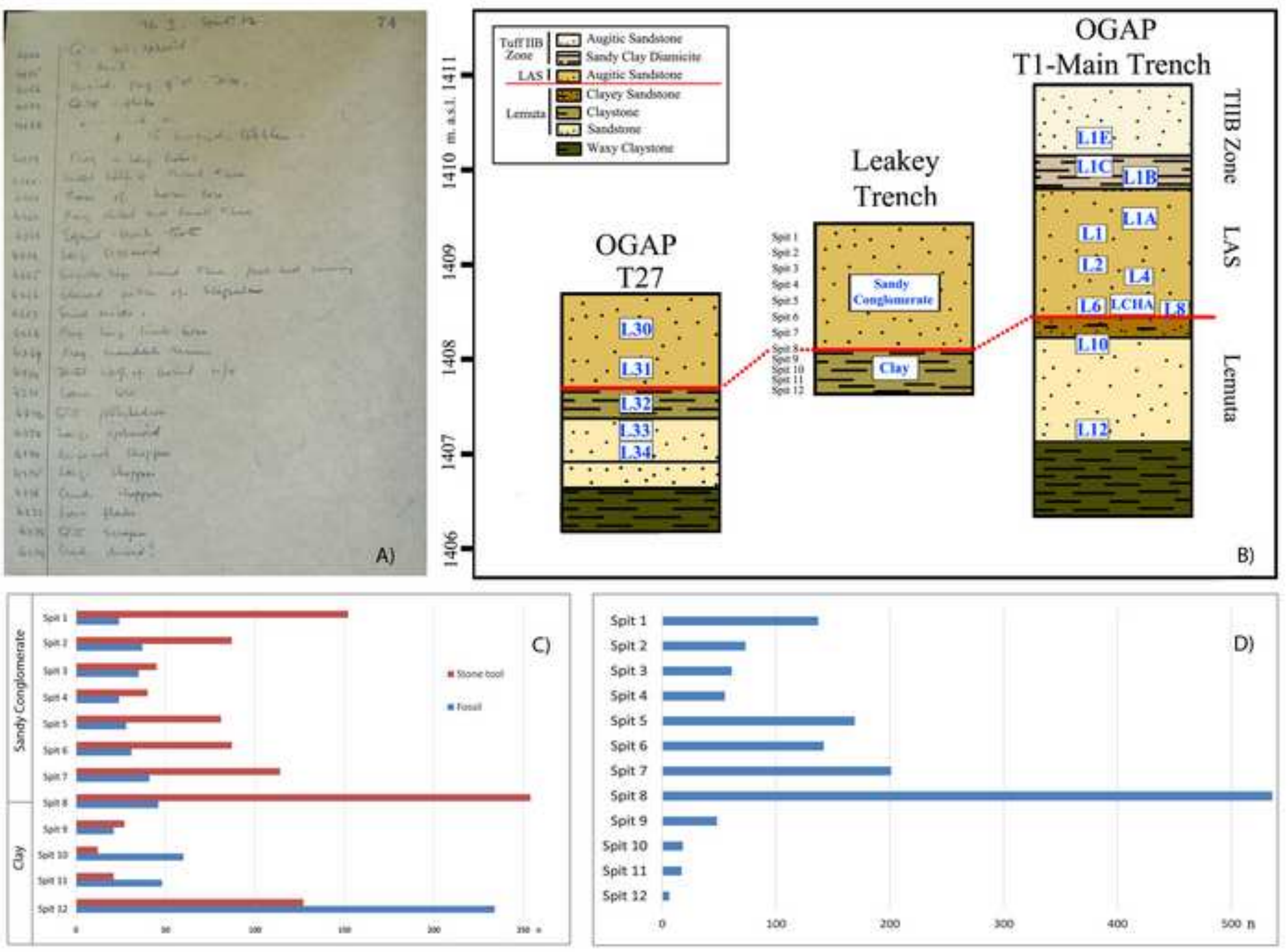


Click here to download high resolution image

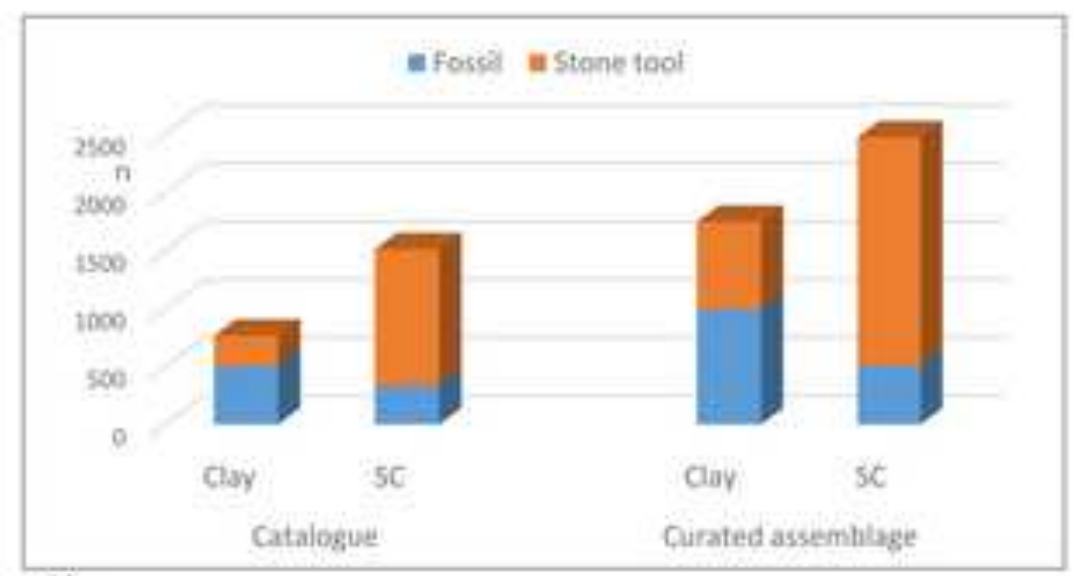

A)

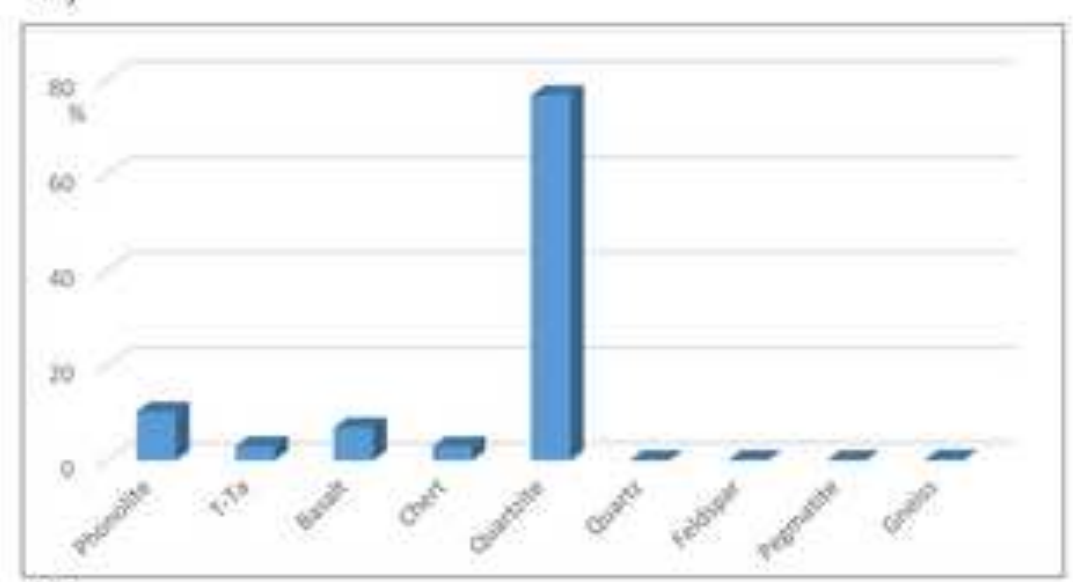

C)

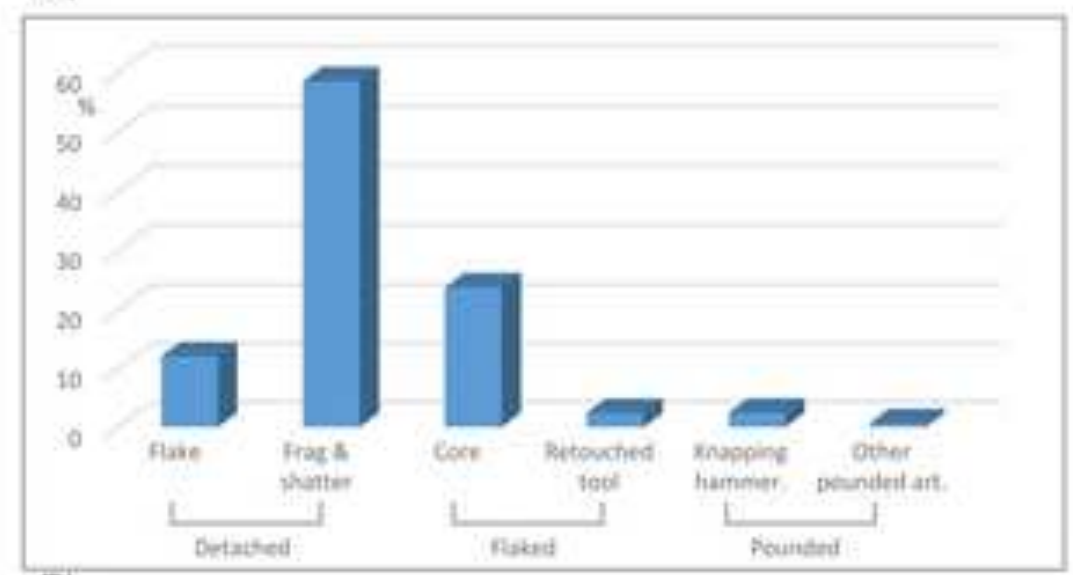

E)

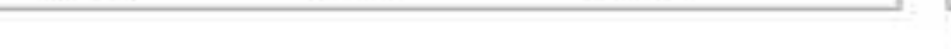

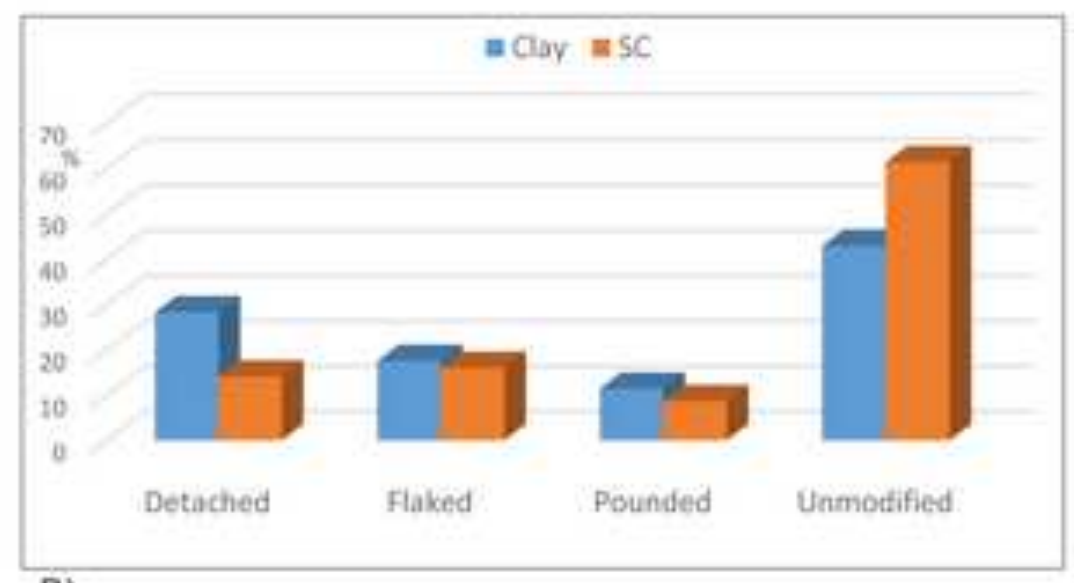

B)

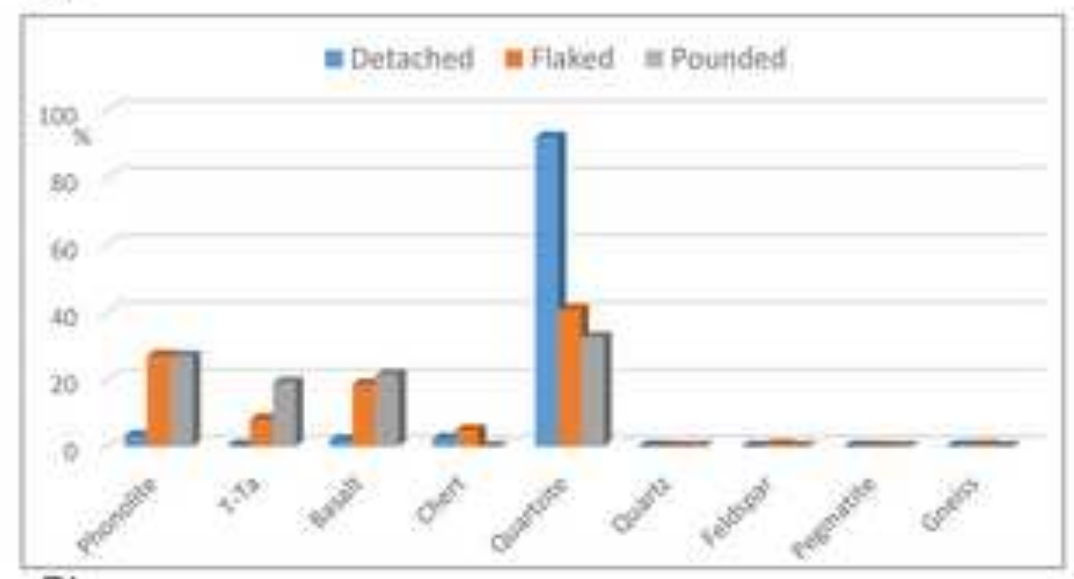

D)

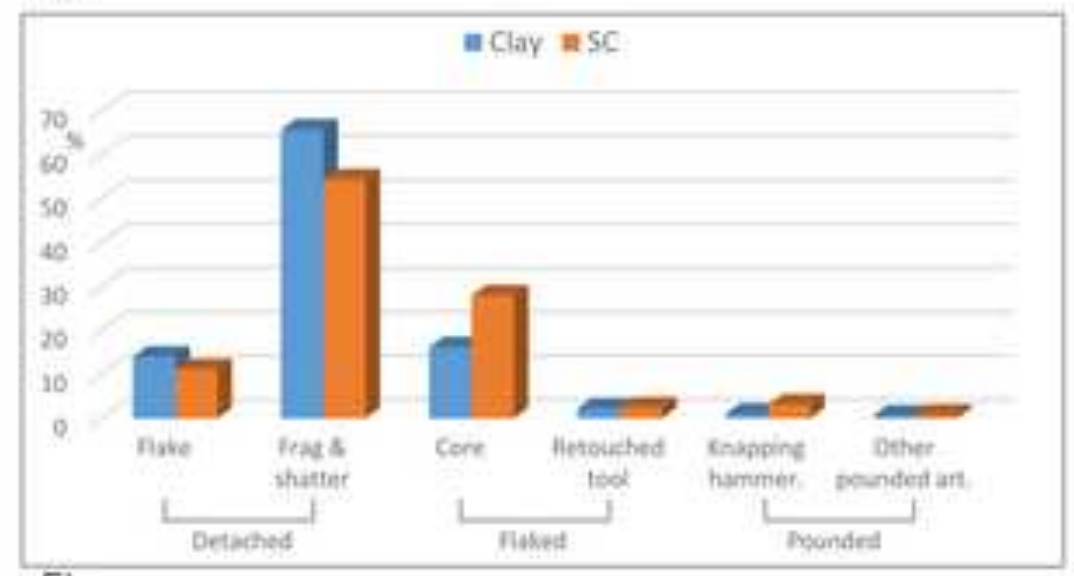

F) 
Click here to download high resolution image

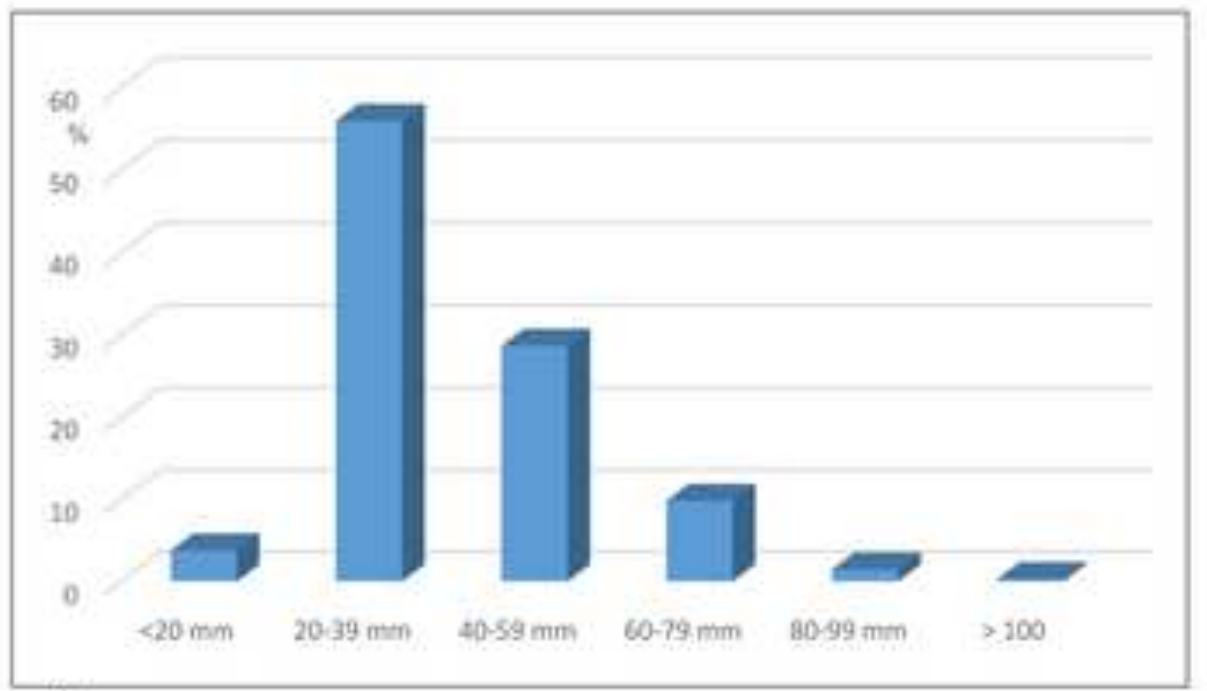

A)

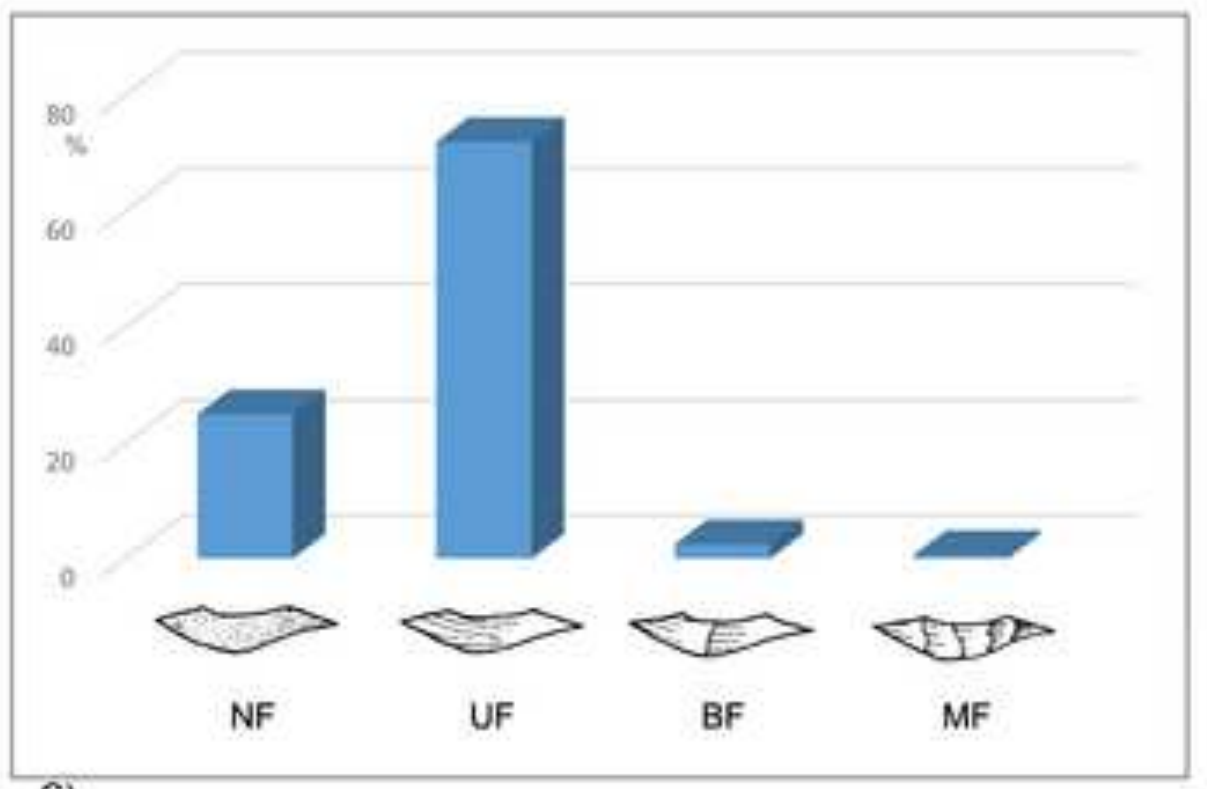

C)

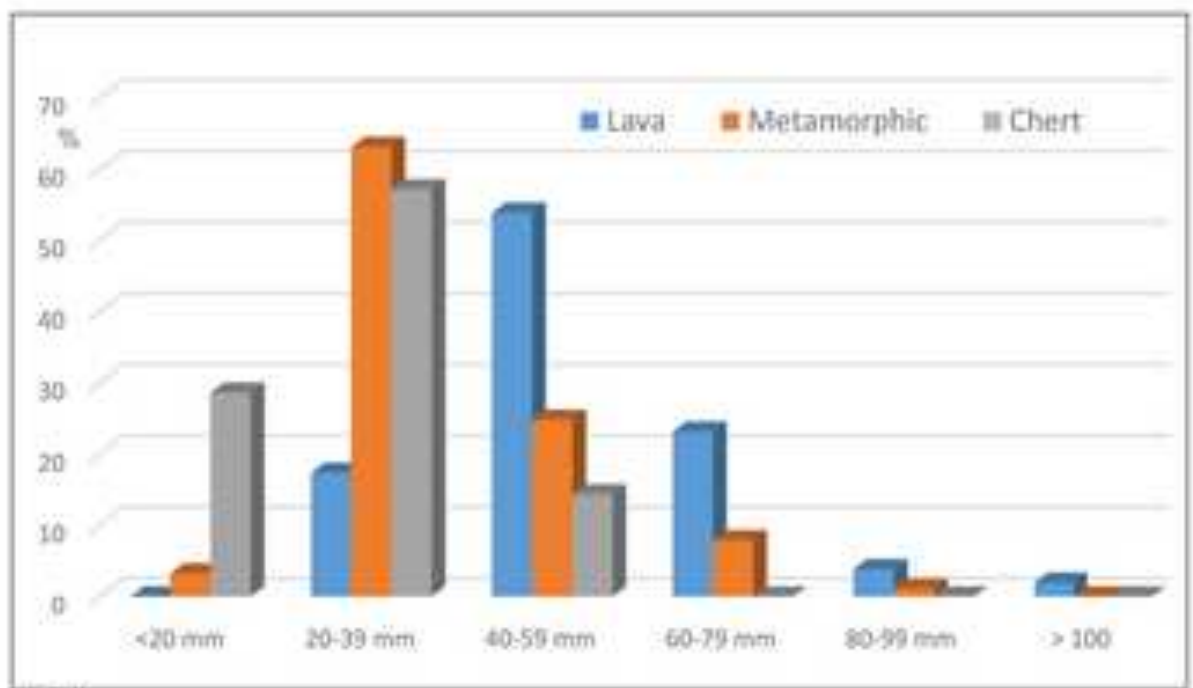

B)

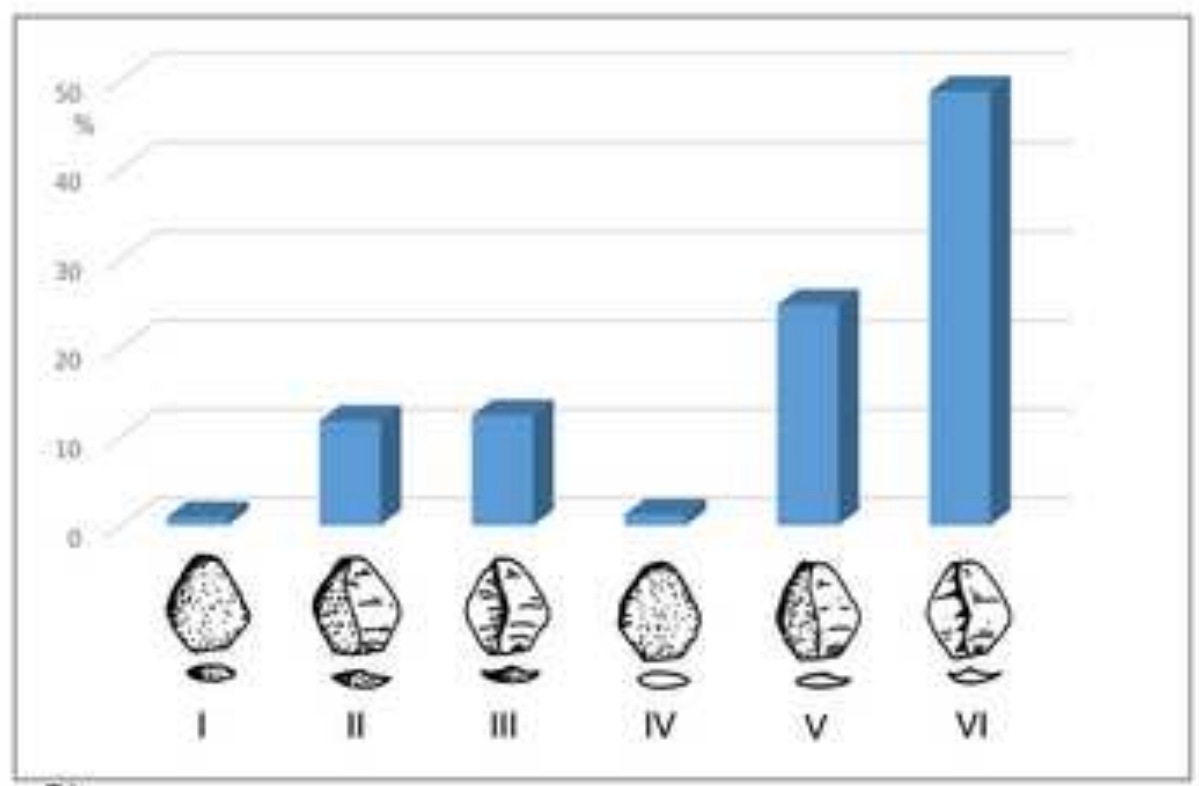

D) 


\section{Figure 5 \\ Click here to download high resolution image}
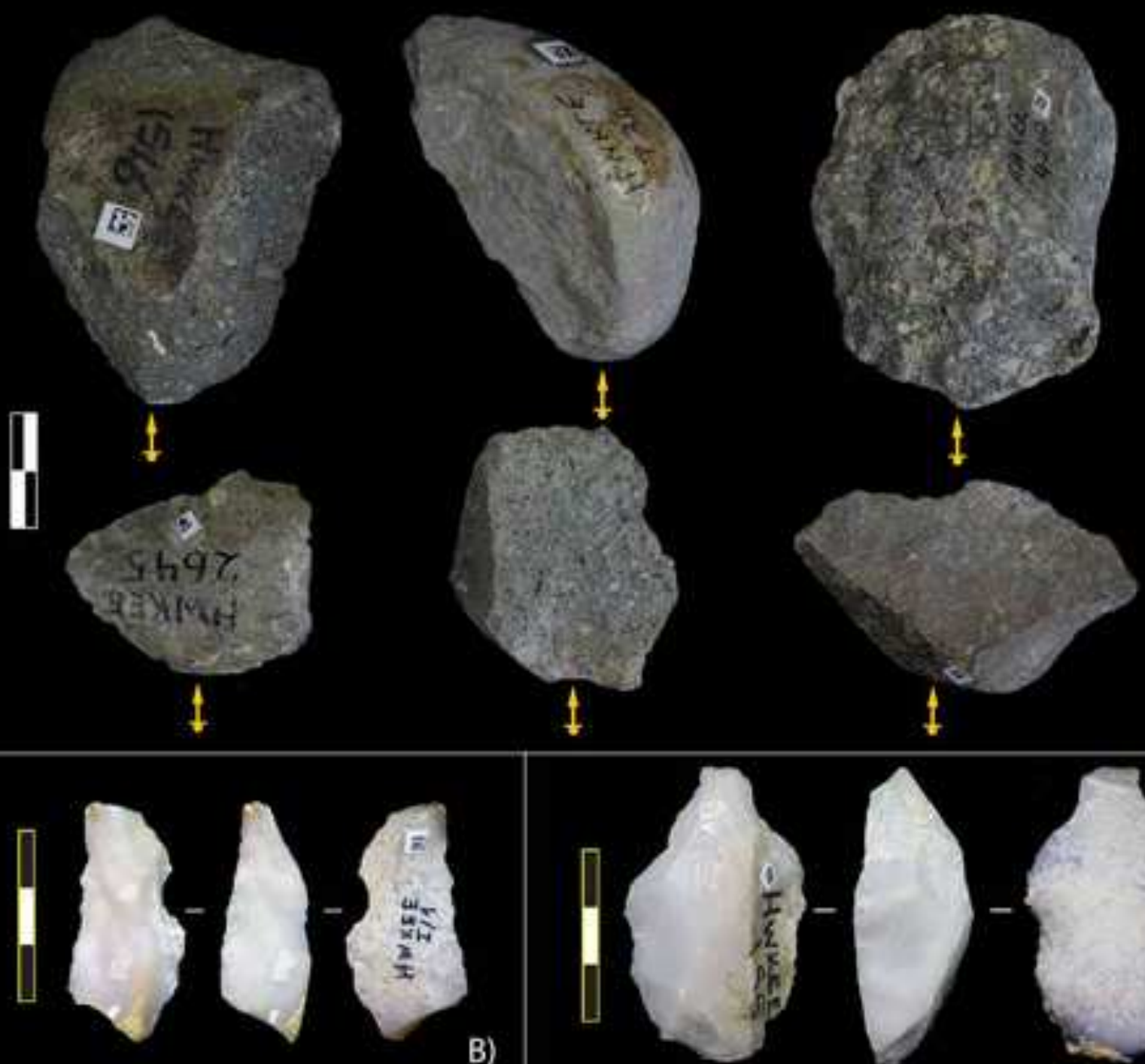

B)
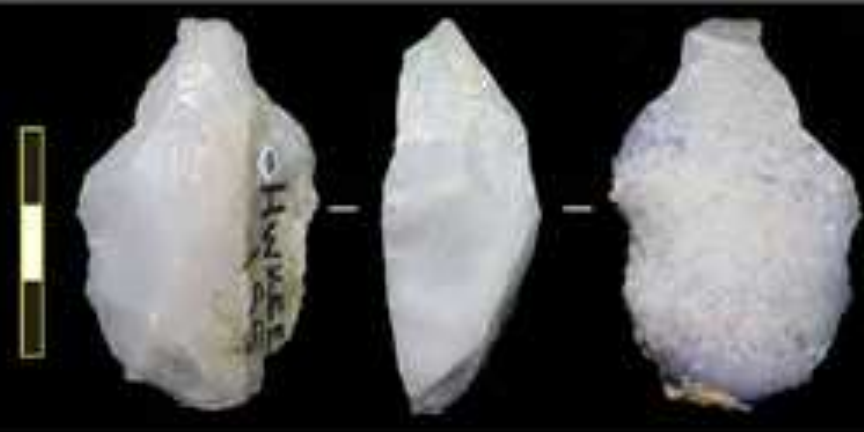

C)
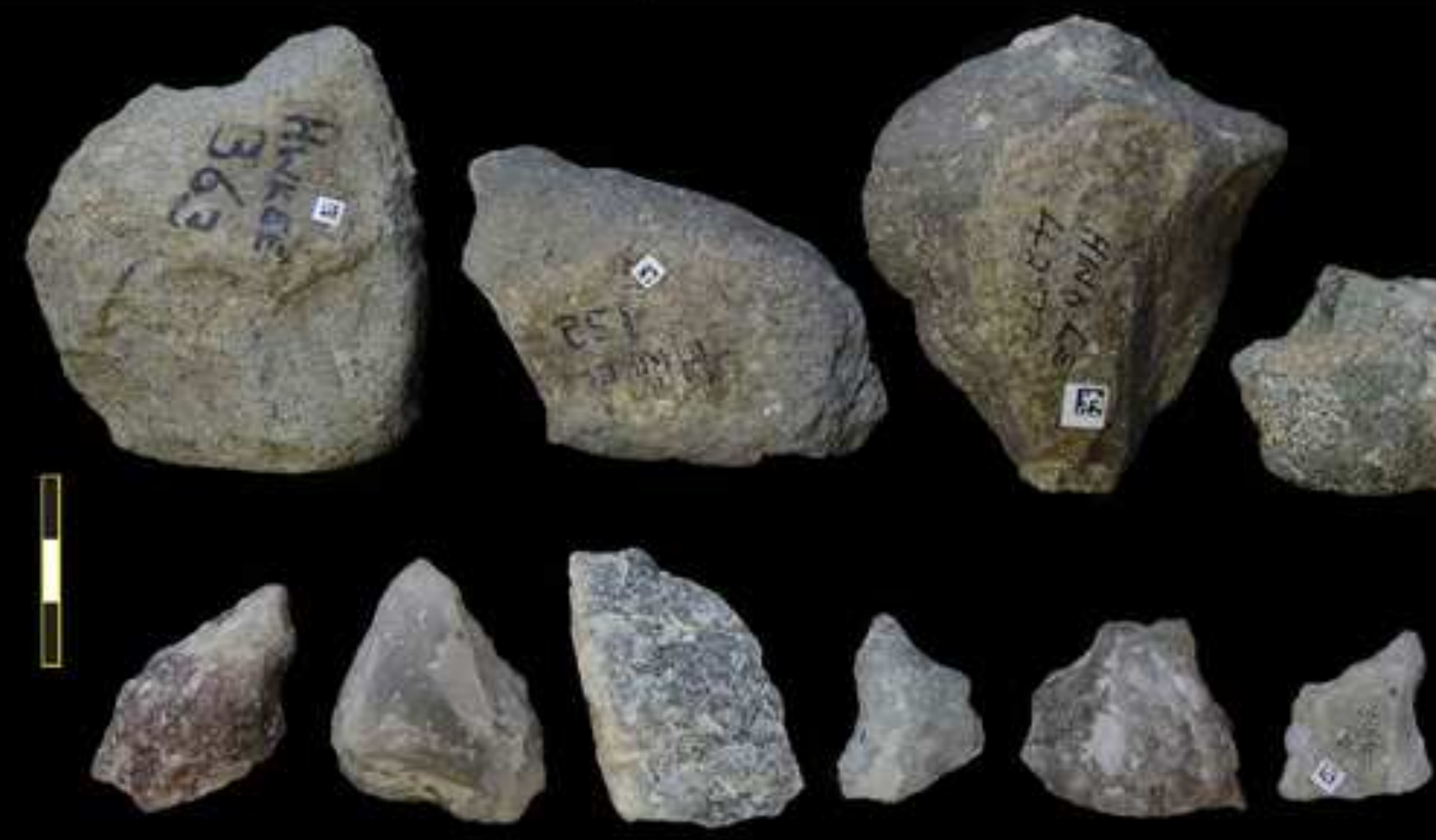

D) 


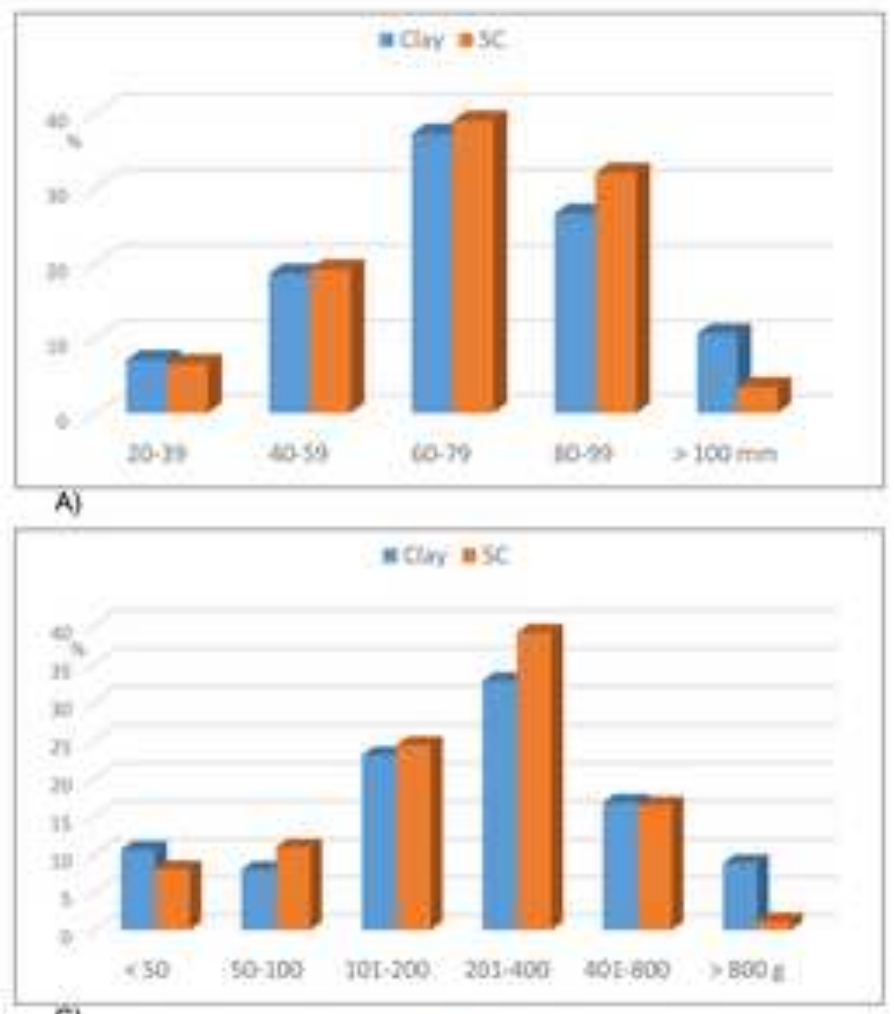

c)

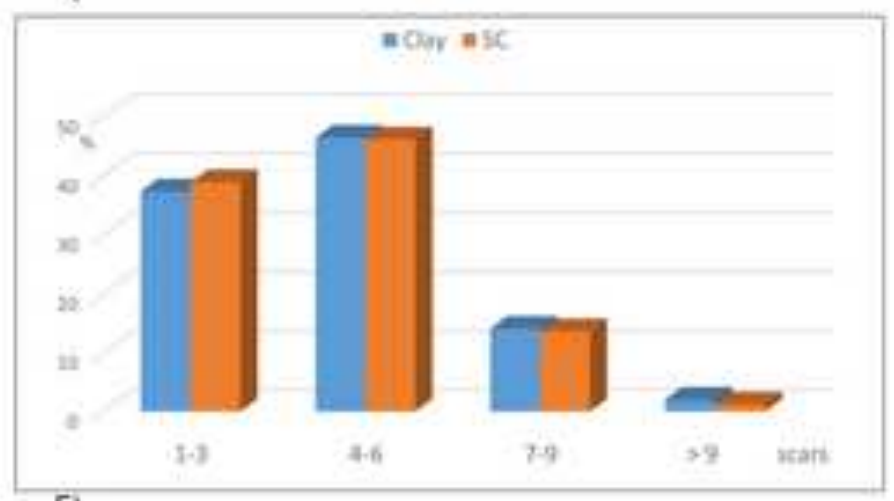

E)

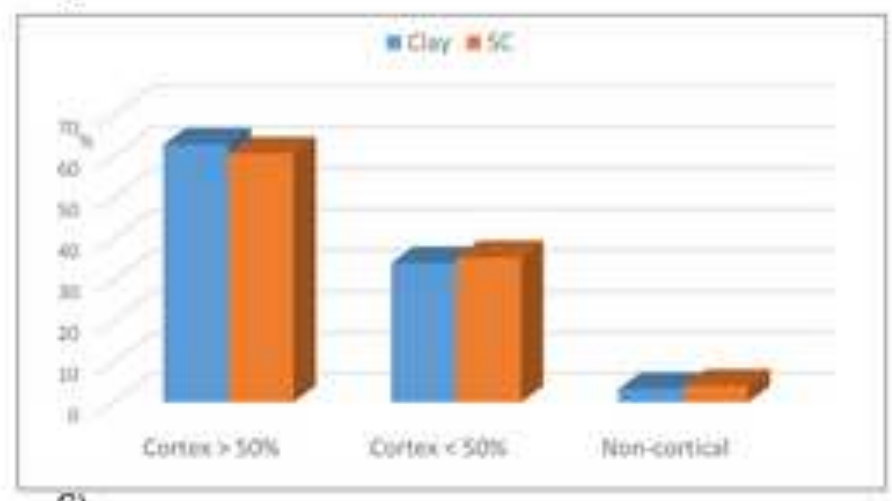

G)
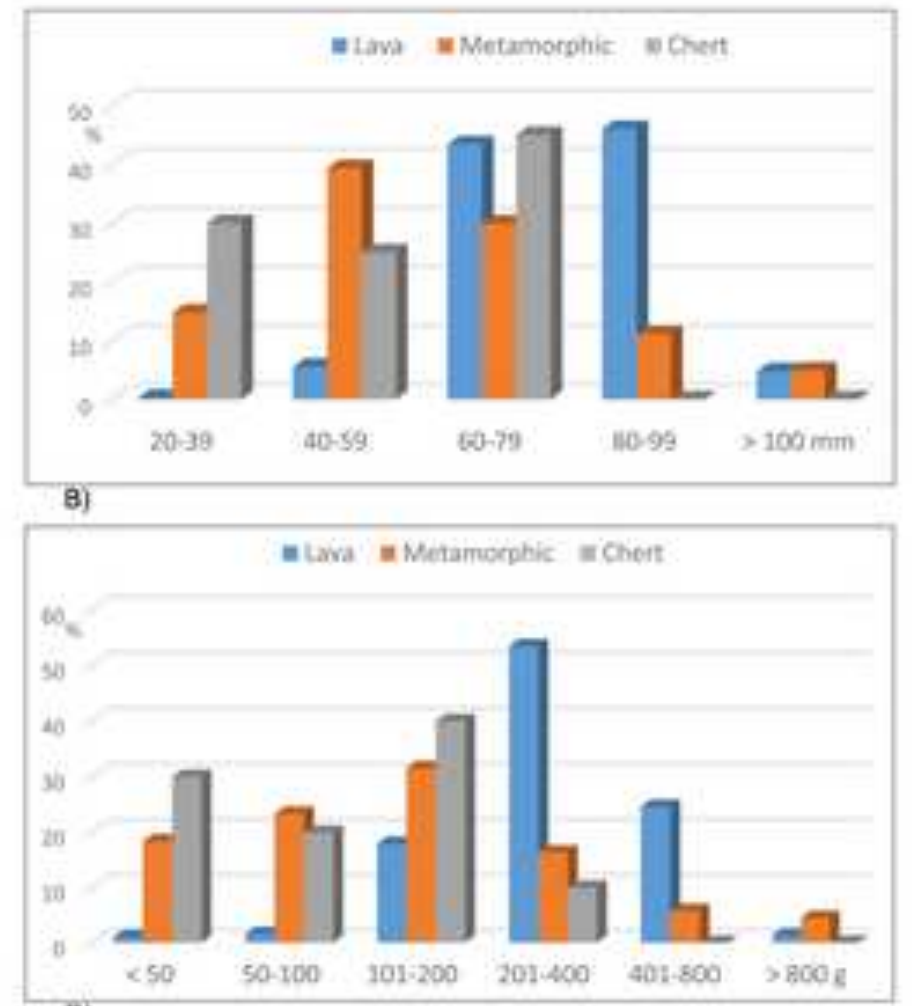

D)
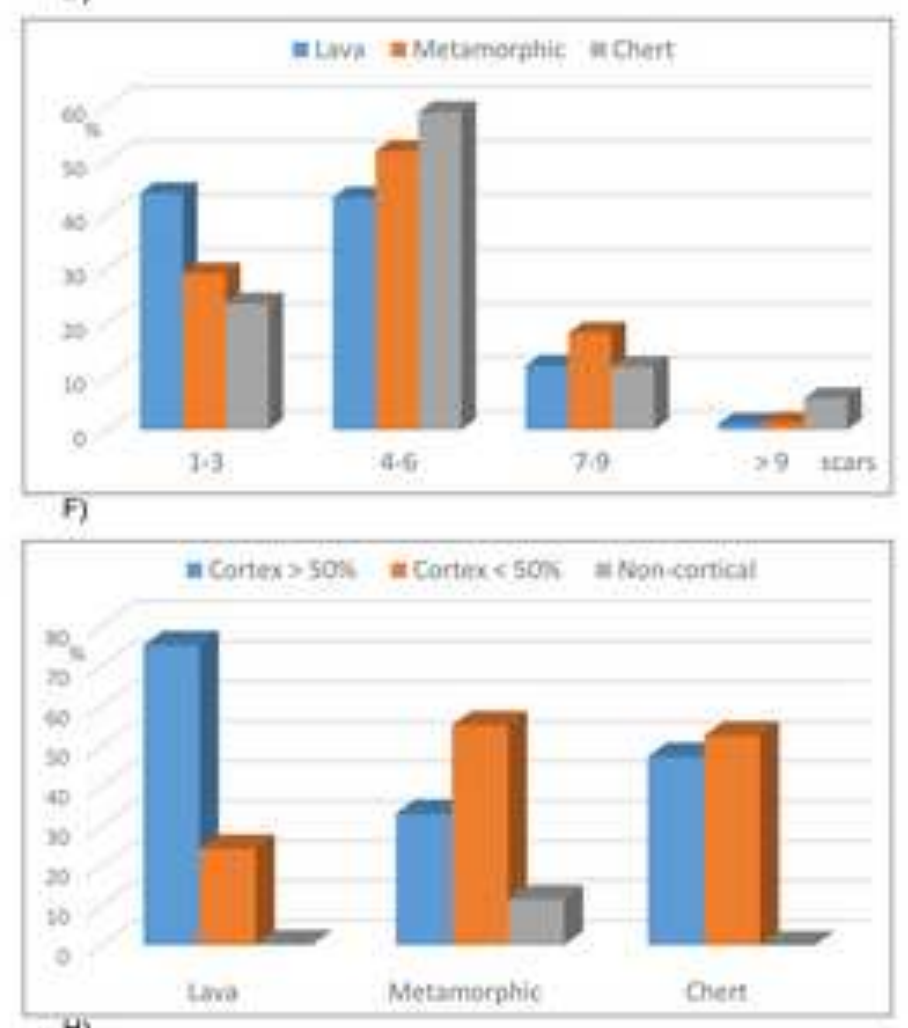

H)

\section{Click here to download high resolution image}


Figure 7
Click here to download high resolution image

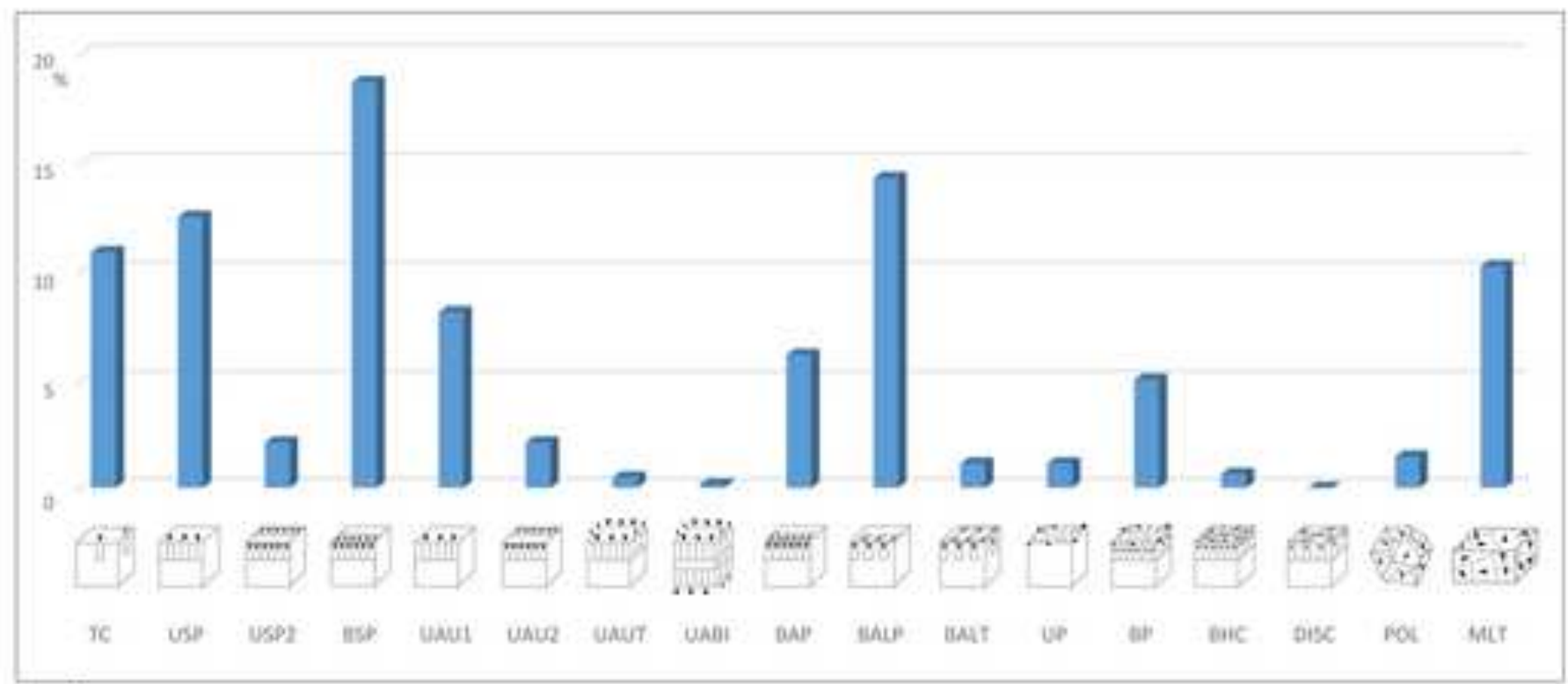

A)

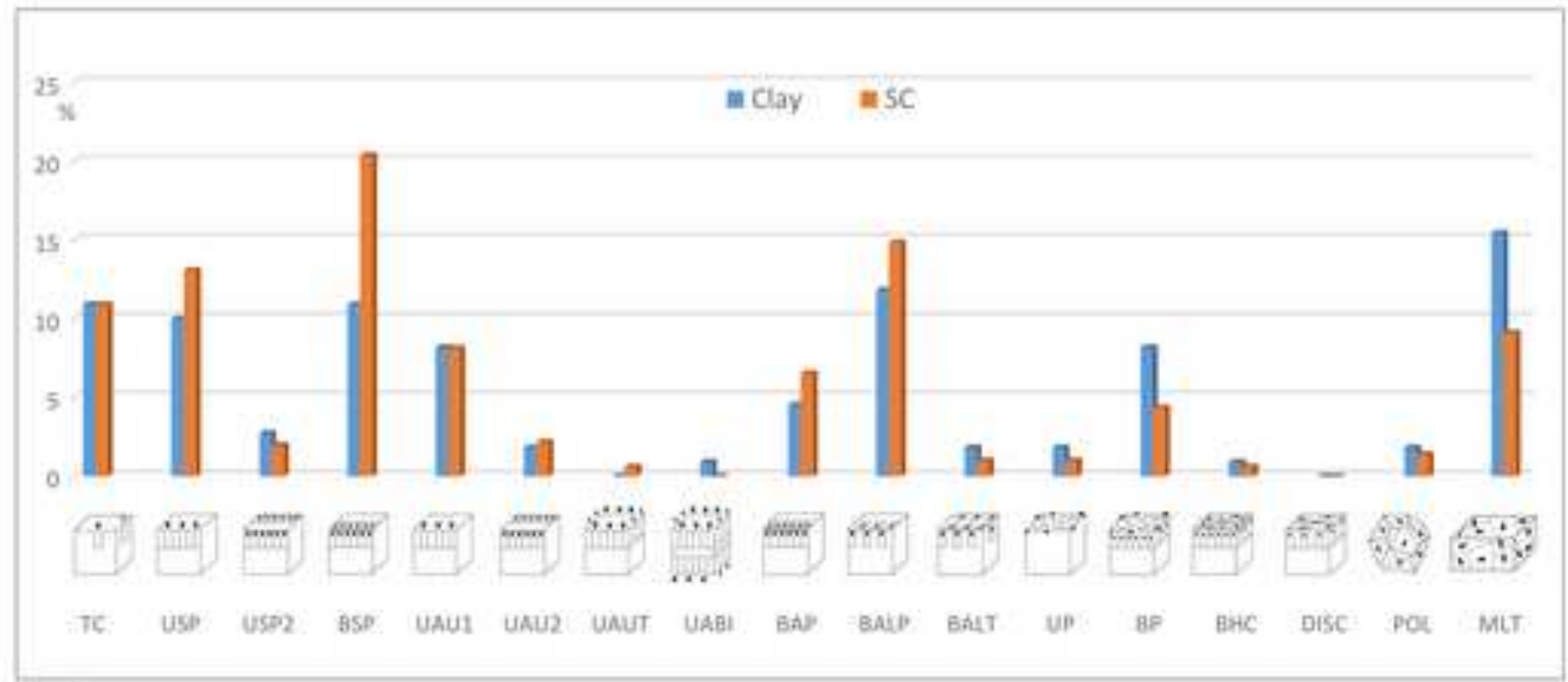

B)

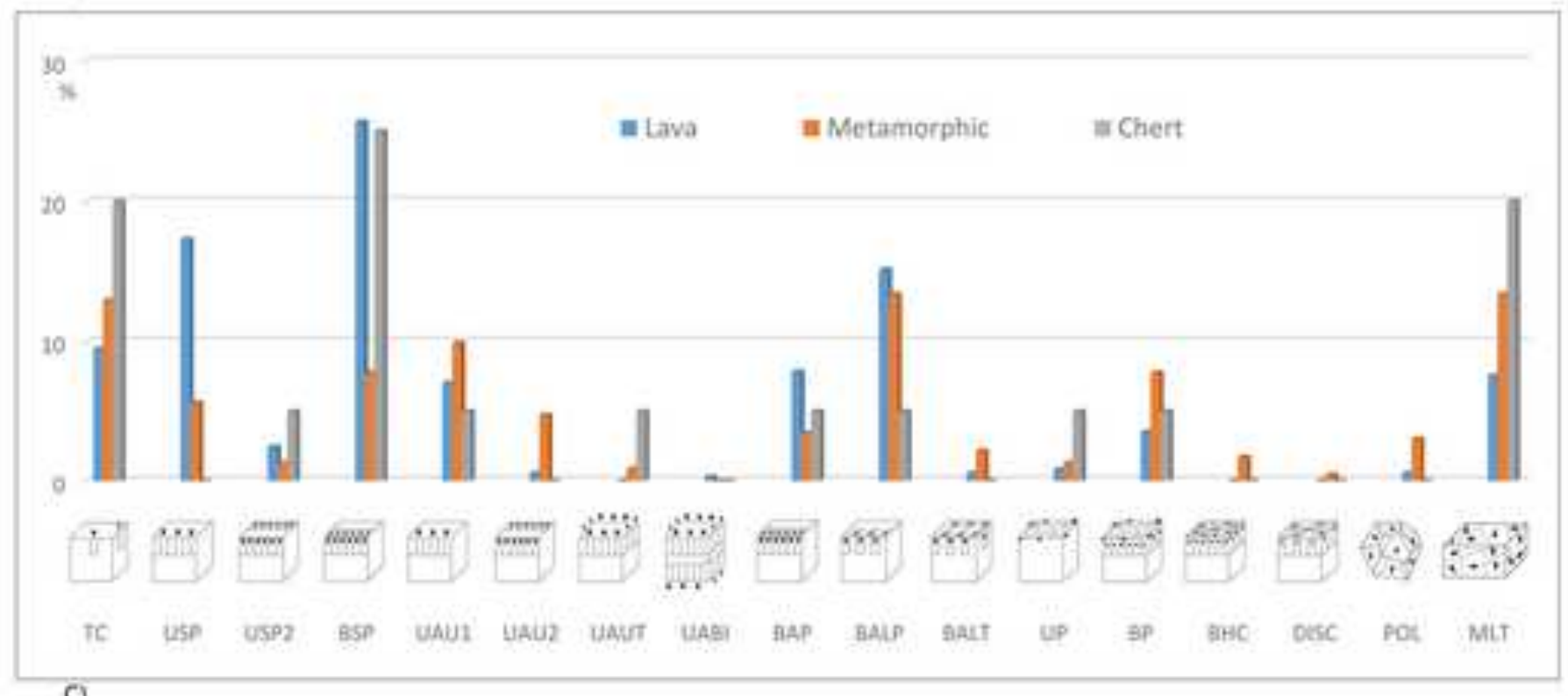

C) 
Click here to download high resolution image
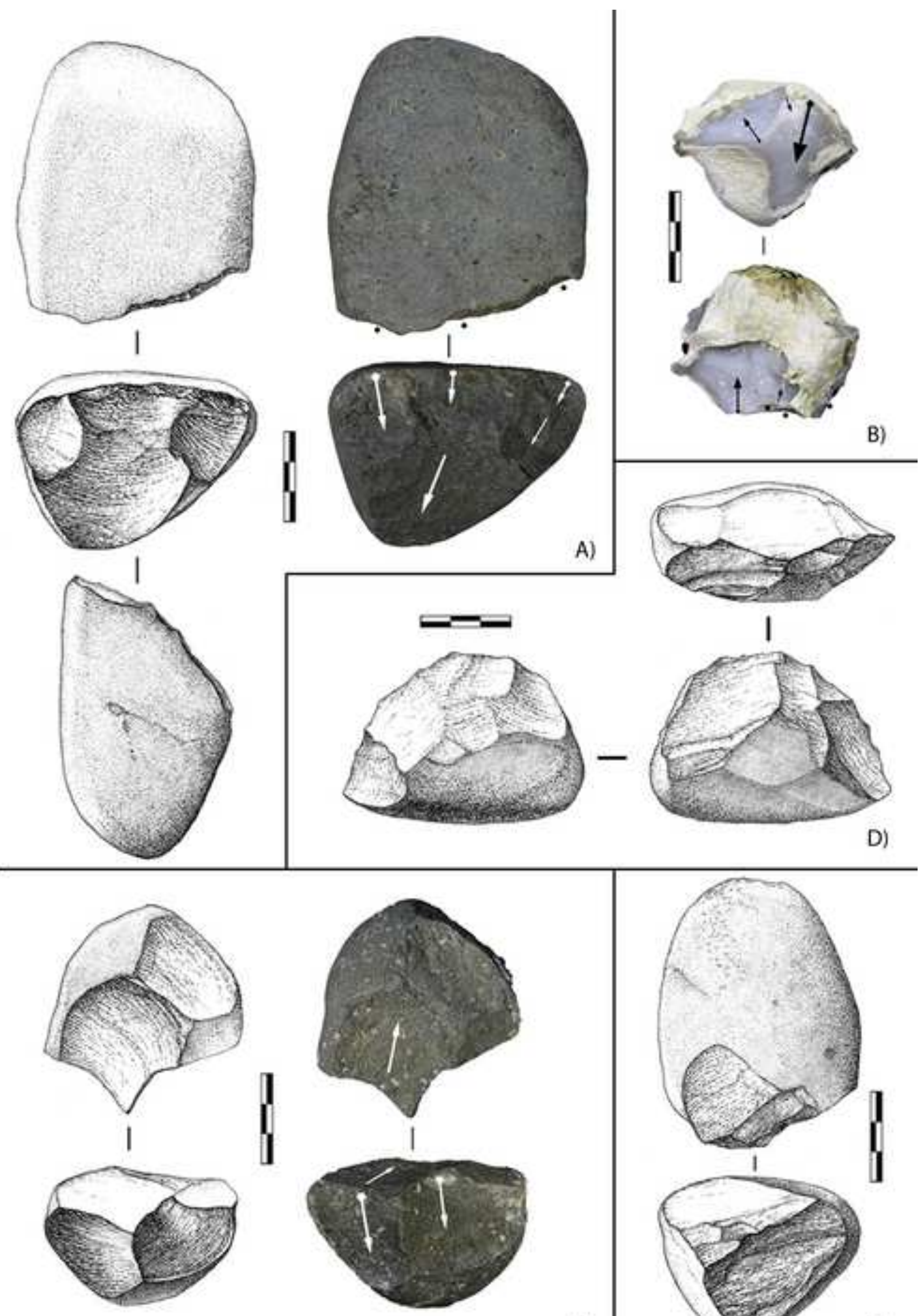

C)

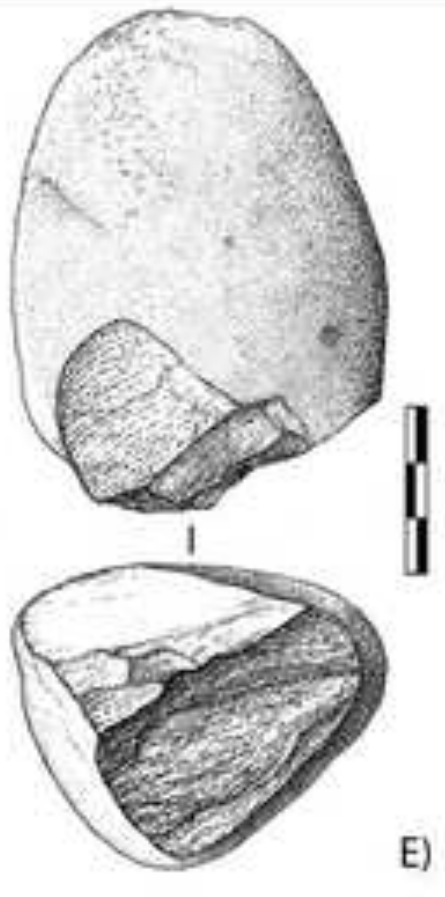




\section{Figure \\ Click here to download high resolution image}
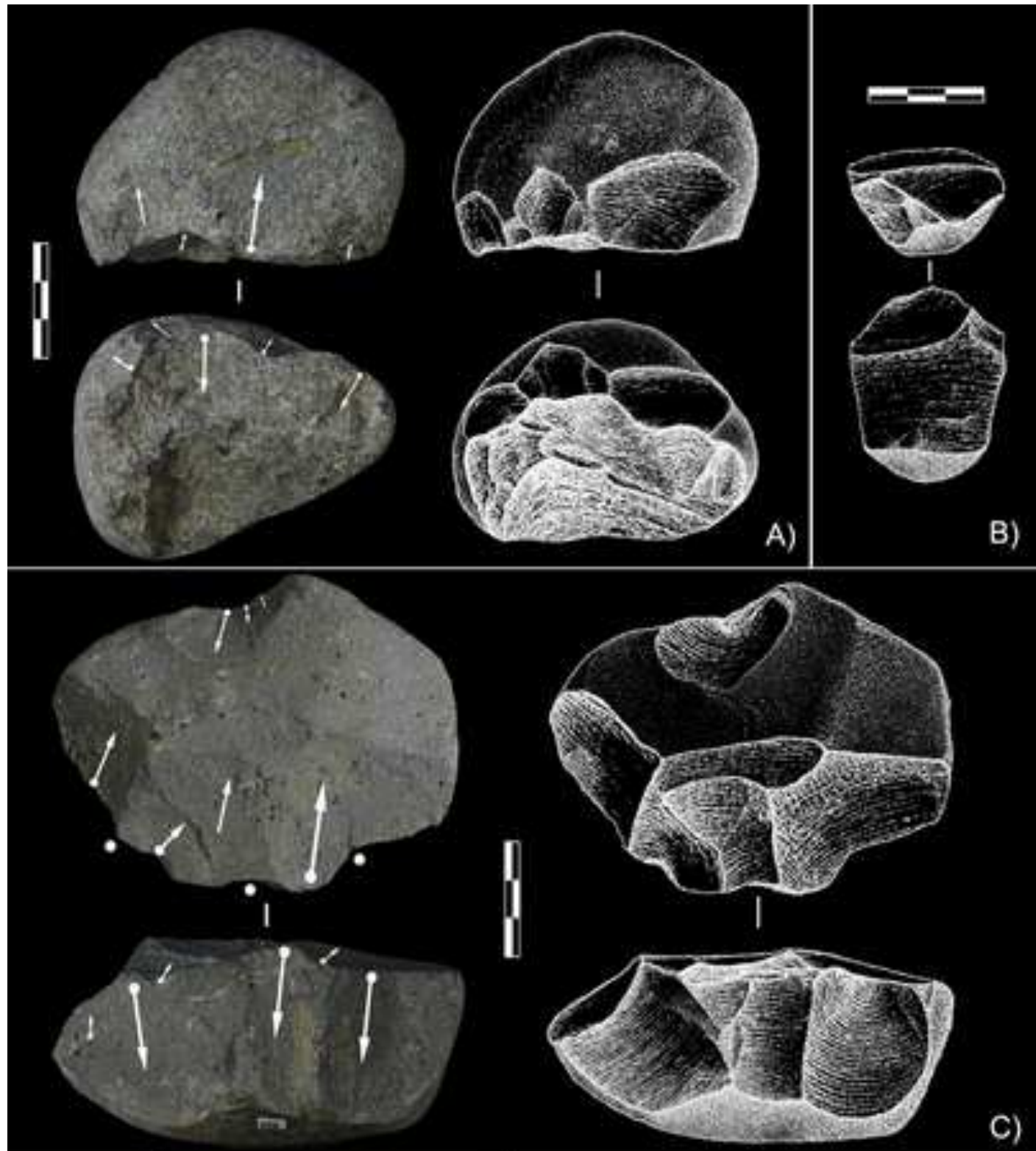

C)

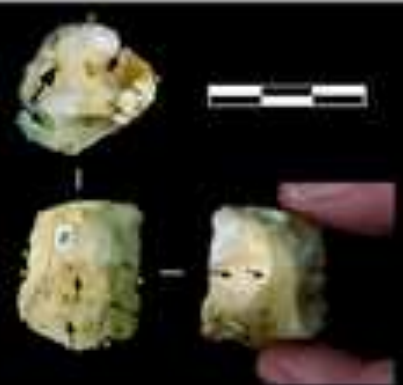

D)

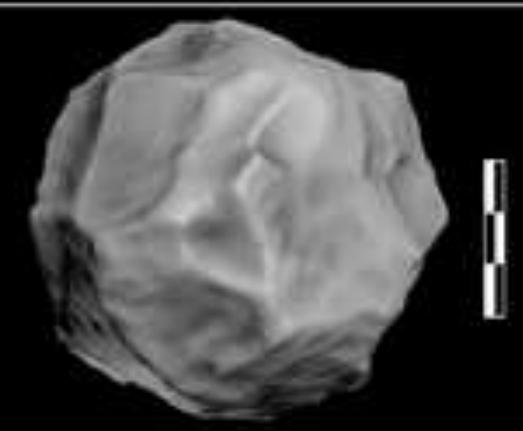

E)

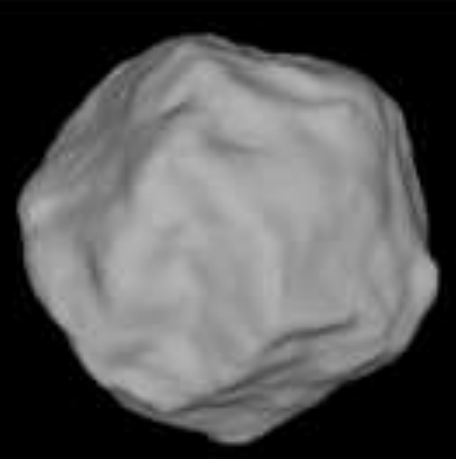

F)

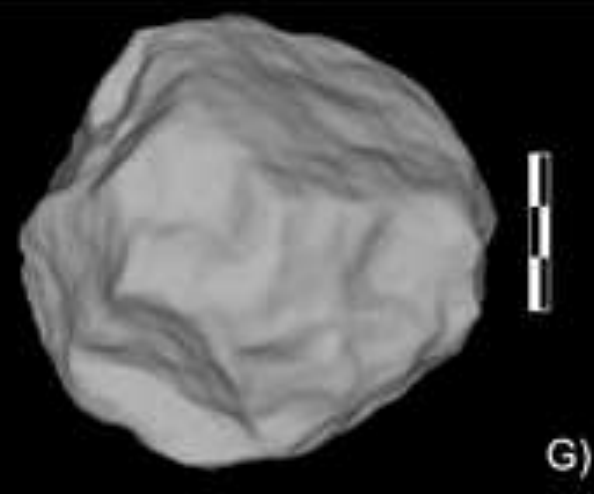

G) 


\section{Figure 10 \\ Click here to download high resolution image}
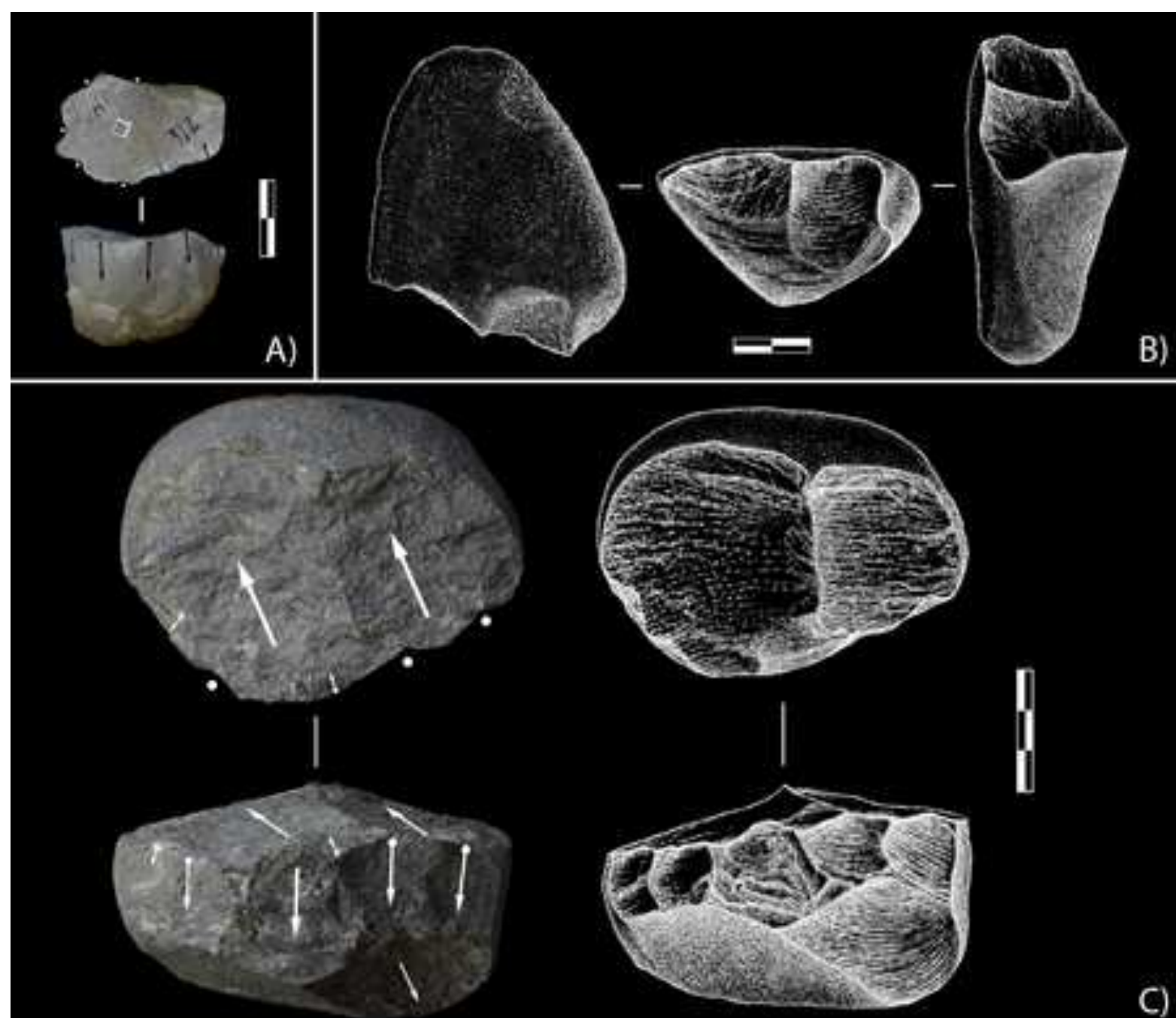

C)

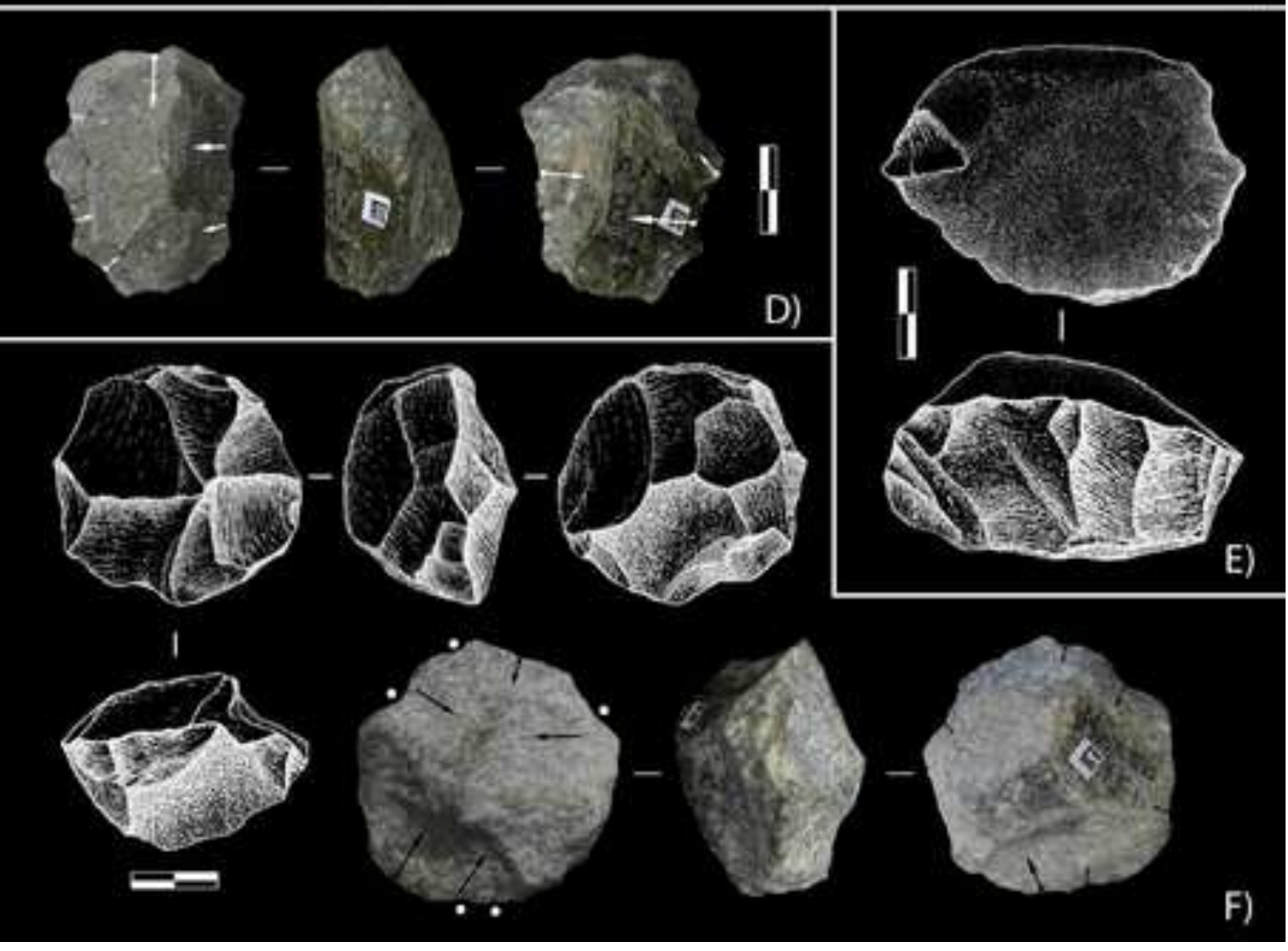


Figure 11

Click here to download high resolution image
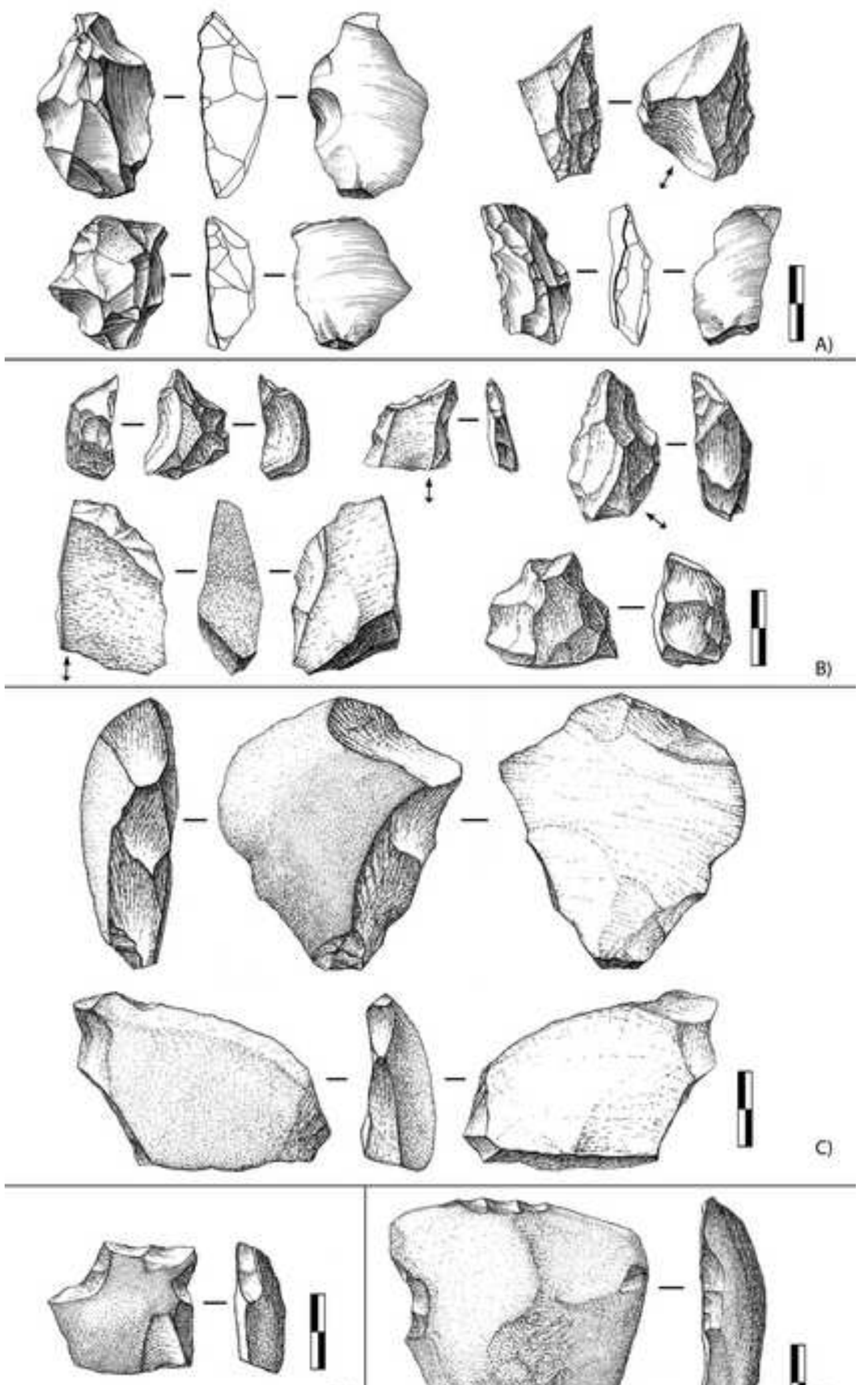

D)

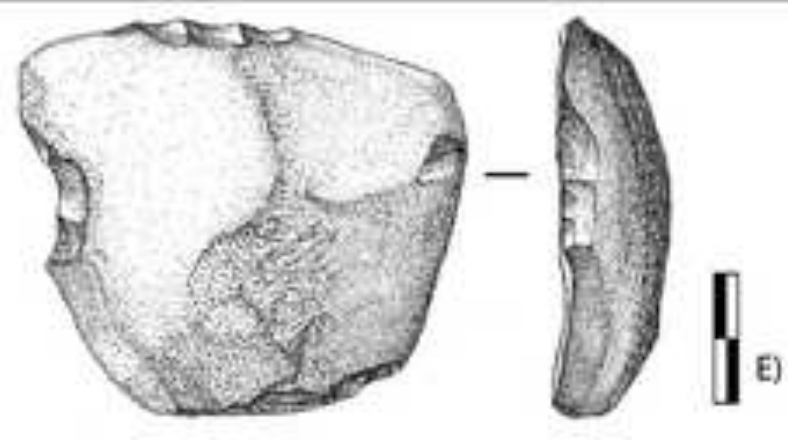




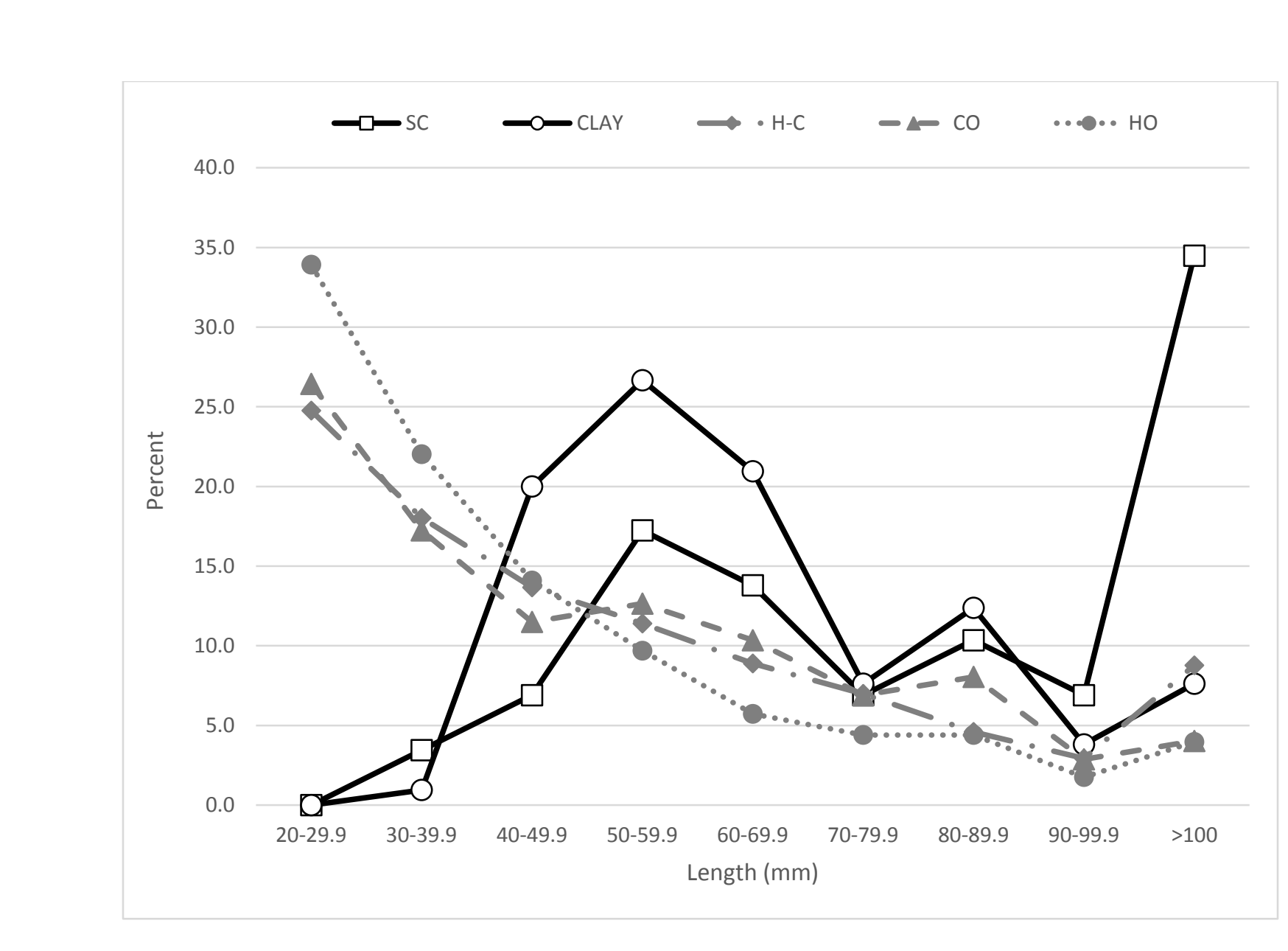

Figure 12
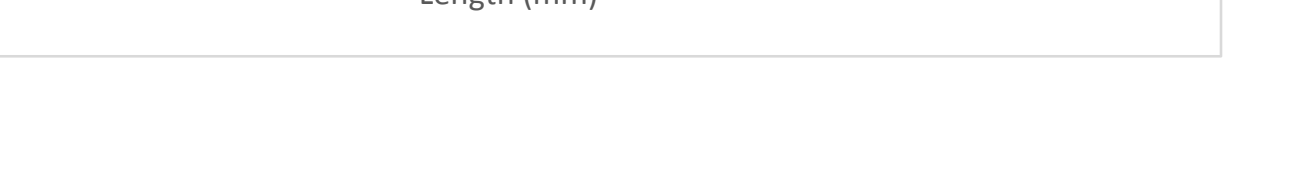


\section{Click here to download high resolution image}

A

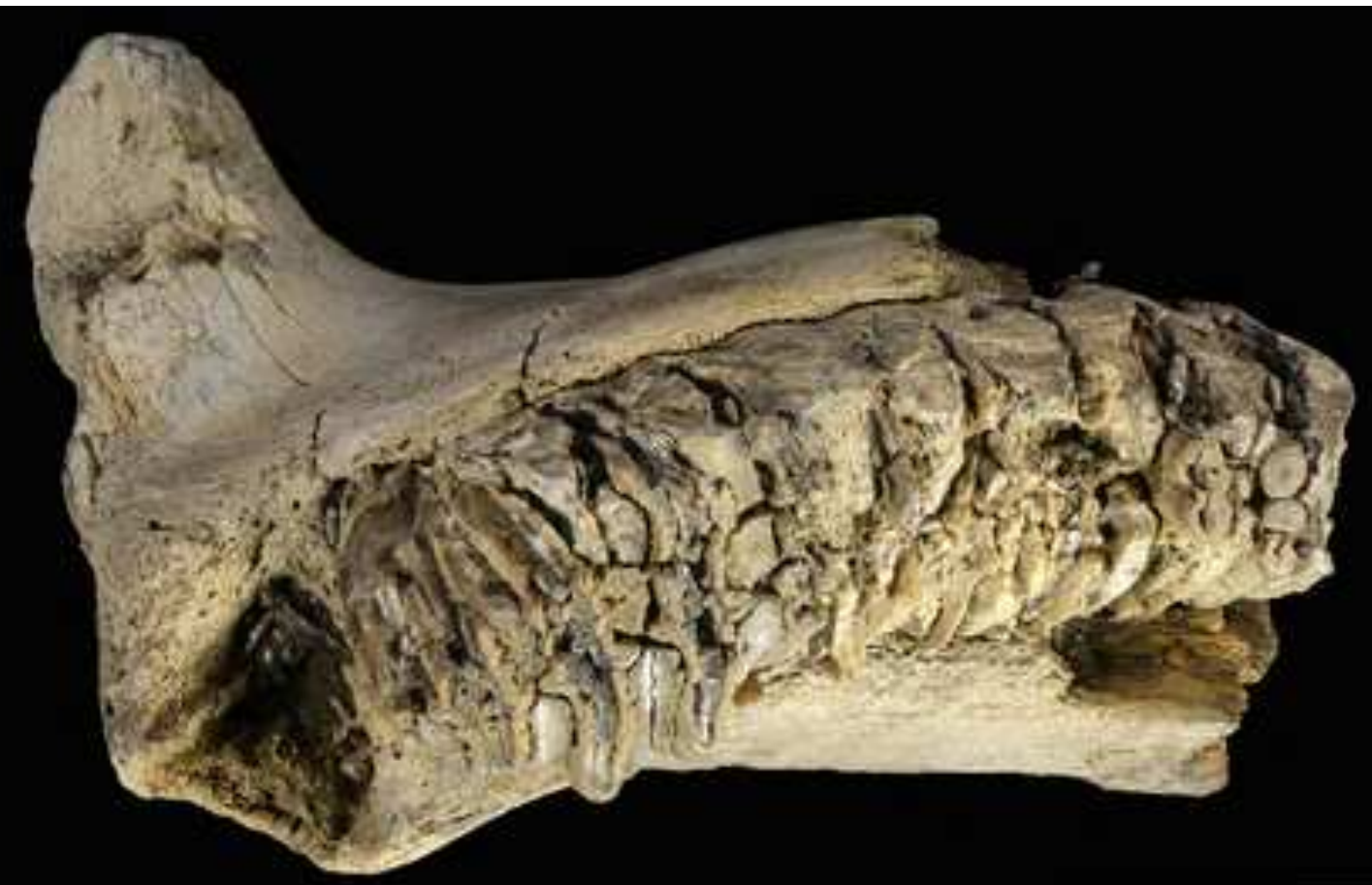

B

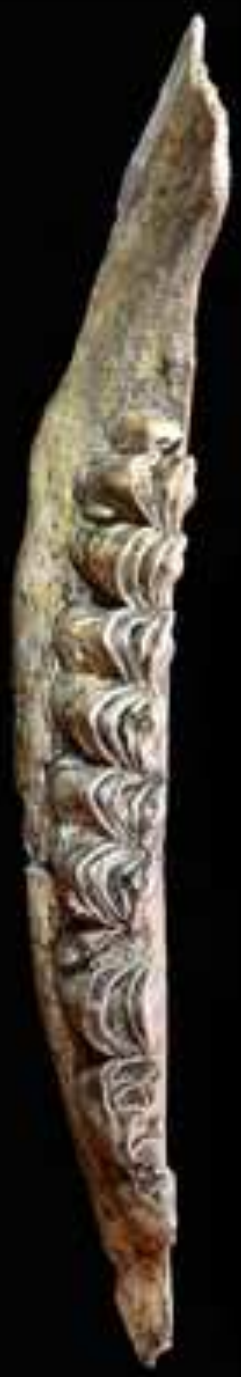

C

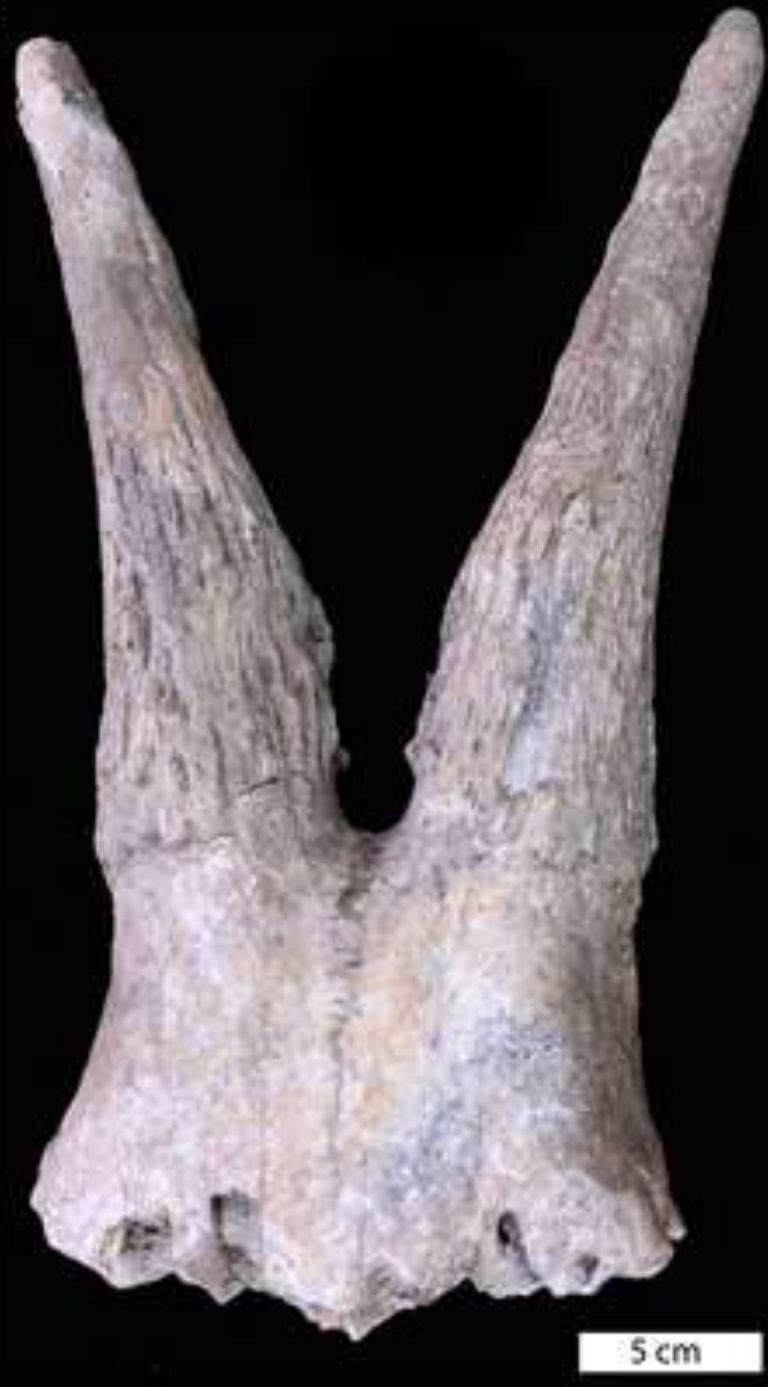




\section{Click here to download high resolution image}

A

B

D
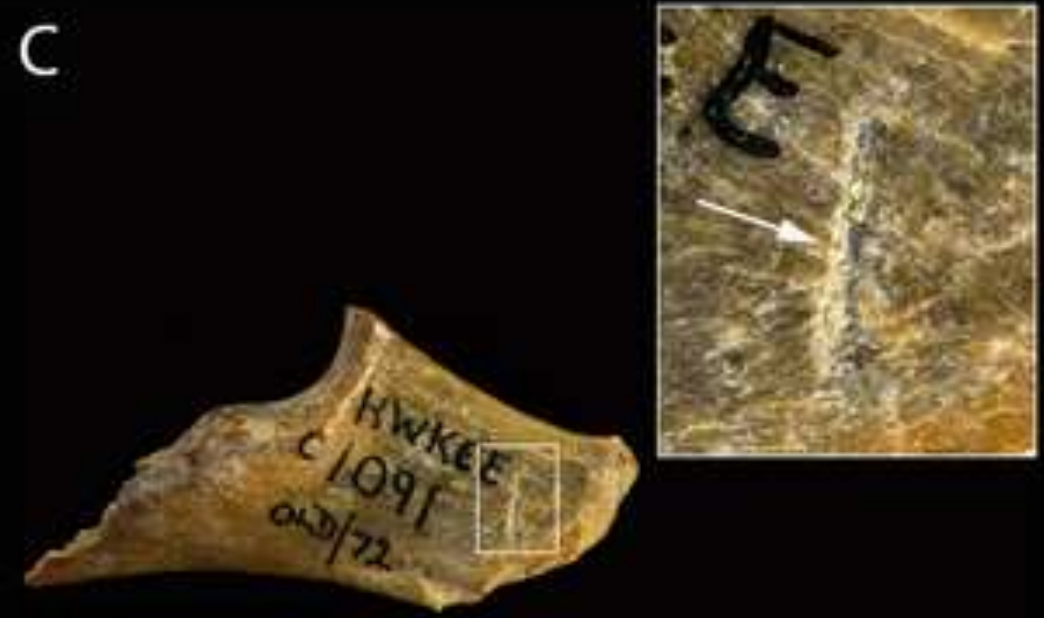

$3 \mathrm{~cm}$

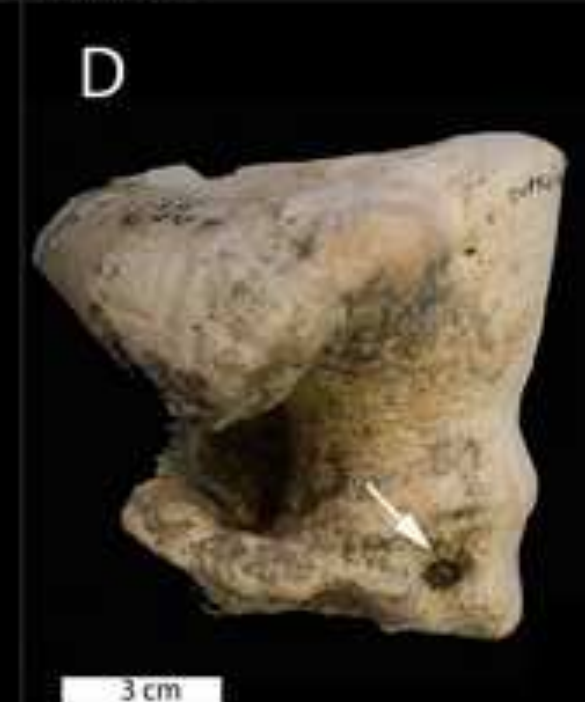

$E$
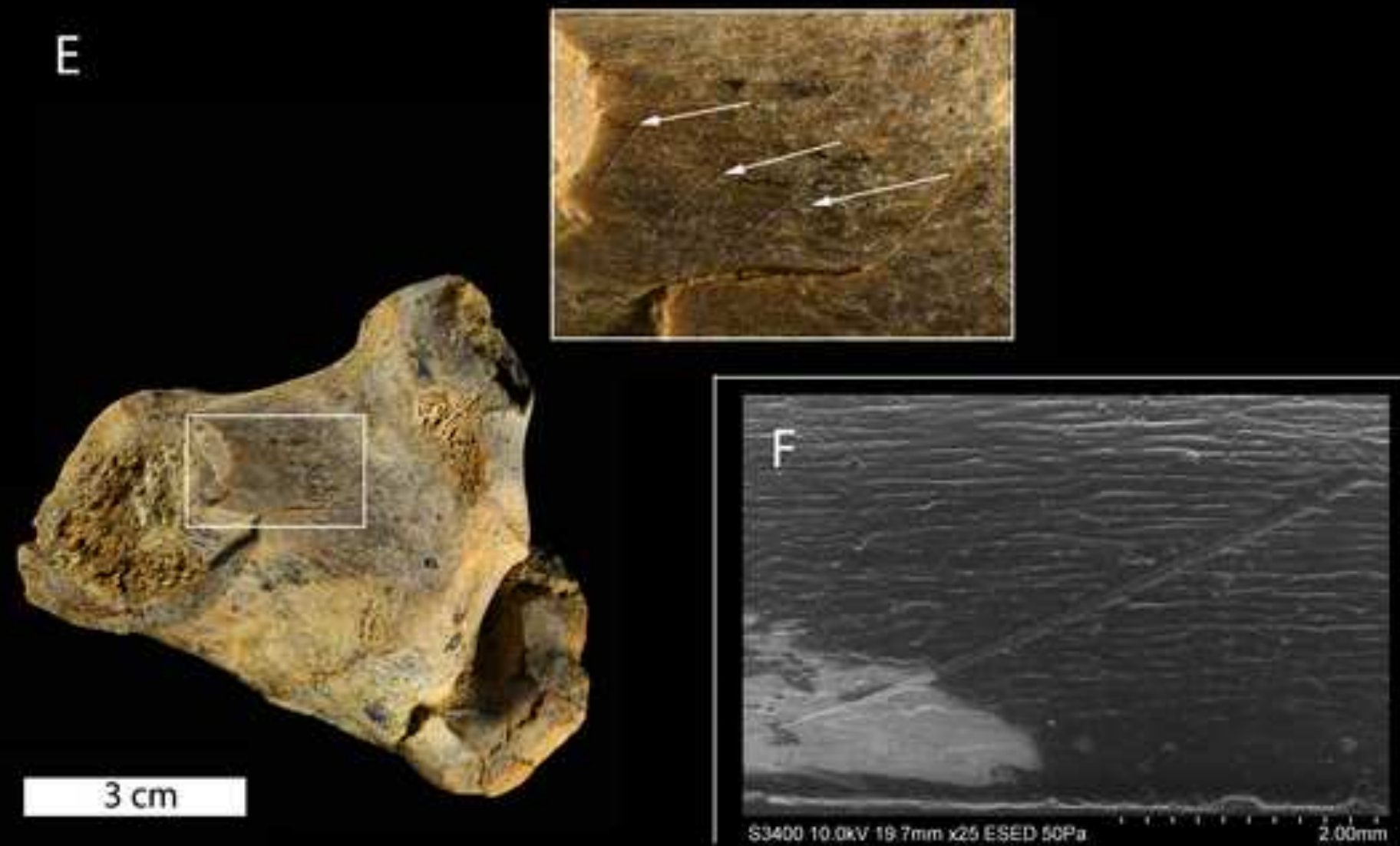